\title{
Microfinance in Latin America: Poverty Alleviation and the Impact of Institutional Mimicry
}

\author{
Lindsay Jouben \\ ljouben@mix.wvu.edu
}

Follow this and additional works at: https://researchrepository.wvu.edu/etd

Part of the Comparative Politics Commons, International Economics Commons, and the International Relations Commons

\section{Recommended Citation}

Jouben, Lindsay, "Microfinance in Latin America: Poverty Alleviation and the Impact of Institutional Mimicry" (2020). Graduate Theses, Dissertations, and Problem Reports. 7728.

https://researchrepository.wvu.edu/etd/7728

This Dissertation is protected by copyright and/or related rights. It has been brought to you by the The Research Repository @ WVU with permission from the rights-holder(s). You are free to use this Dissertation in any way that is permitted by the copyright and related rights legislation that applies to your use. For other uses you must obtain permission from the rights-holder(s) directly, unless additional rights are indicated by a Creative Commons license in the record and/ or on the work itself. This Dissertation has been accepted for inclusion in WVU Graduate Theses, Dissertations, and Problem Reports collection by an authorized administrator of The Research Repository @ WVU.

For more information, please contact researchrepository@mail.wvu.edu. 
Microfinance in Latin America:

Poverty Alleviation and the Impact of Institutional Mimicry

\author{
Lindsay Jouben \\ Dissertation submitted to Eberly College \\ at West Virginia University \\ in partial fulfillment of the requirements for the degree of \\ PhD. in \\ Political Science/International Relations
}

\author{
Joe D. Hagan, Ph.D., Chair \\ Christina Fattore, Ph.D. \\ John Kilwein, Ph.D. \\ Gregory Noone, Ph.D. \\ Robert Duval, Ph.D. \\ Melissa Latimer, Ph.D. \\ Department of Political Science
}

Morgantown, West Virginia

2020

Keywords: Microfinance, economic development, poverty alleviation, gender Copyright 2020 Lindsay Jouben 


\section{$\underline{\text { Abstract }}$ \\ Microfinance in Latin America: Poverty Alleviation and the Impact of Institutional Mimicry}

\section{Lindsay Jouben}

Microfinance has become a program of choice in the international development community. The World Bank has promoted microfinance programs under the idea that poverty alleviation can be accomplished by mainly providing credit. ${ }^{1}$ As such, these policies are often replicated throughout the developing world. This replication is done through international organizations adopting a standard of best practices for the microfinance field. Best practices consist of a complex set of standard by which all banks must adhere if they receive funding from the World Bank or International Monetary Fund. These best practices, following neoliberal economics, lay out how microfinance should operate according to the World Bank. This dissertation looks specifically at this replication through institutional mimicry by questioning the actual impact of the neoliberal economic policies enshrined in the best practices model of microfinance. It examines several distortions that neoliberal best practices create on two dimensions: economic and socio-cultural. The economic distortions concern issues of debt cycles, self-sufficiency, and the role of the economically active poor with the argument that clients who participate in Microfinance Institutions (MFIs) face increasing levels of poverty. Furthermore, it is argued that socio-cultural distortions like social capital creation, local conditions, and gender targeting increase poverty as well. Using a comparative case study analysis of MFIs in Latin America, this dissertation demonstrates economic and socio-cultural effects for MFIs departing from best practices: first, the lower level of indebtedness of their clients and, second, the offering of a wider array of social programs in the community. These findings are a preliminary indication that departing from best practices contributes to poverty alleviation. Essentially, I argue that for microfinance to be successful it needs to question neoliberal best practices within microfinance policies and focus on tailoring microfinance programs to local political and social conditions.

${ }^{1}$ Vivienne Walt "Does Microfinance Really Work? A New Book Says No" Time (Jan 2012), http://content.time.com/time/world/article/0,8599,2103831,00.html 


\section{Table of Contents}

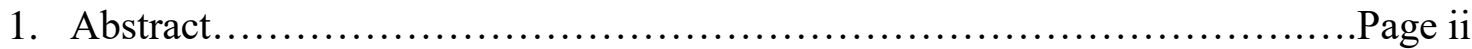

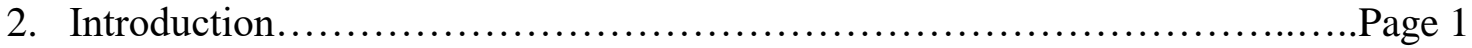

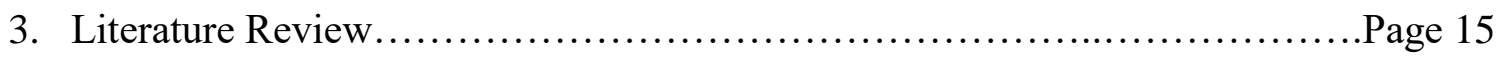

4. Theoretical Chapter................................................... 61

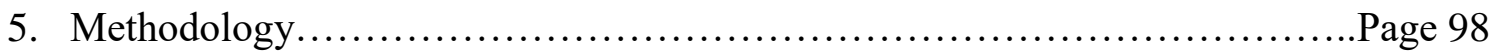

6. Empirical Chapter: Microfinance, Best Practices, Gender, and

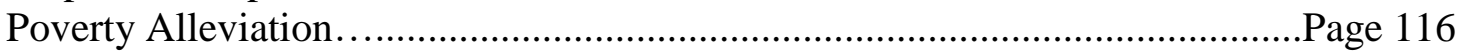

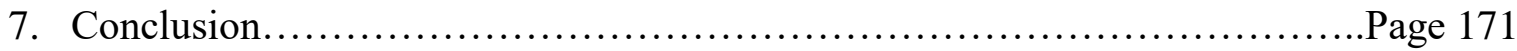

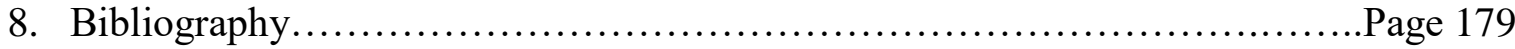




\section{Chapter ONe}

\section{INTRODUCTION}

The phenomenon of microfinance is increasingly pervasive in less developed countries.

Microfinance, at its core, is a collection of banking practices built around providing small loans, usually without collateral, and accepting small savings deposits. The larger intent of microfinance is that the provision of such small loans will lead to broader income generating activities and enterprises. Ideally microfinance is set up to allow the poor to have access to the capital they need to create or expand a microenterprise and generate income, and therefore be able to build both individual and community assets. With access to microloans, therefore, every poor individual and poor community would possess the potential to reduce their own poverty and create sustainable bottom-up economic and social development. The microfinance industry has spawned an important political connection between women's empowerment, and loans, which has created a social cause for donors and Microfinance Institutions (MFIs) to get behind and continue to fund microfinance programs. With this in mind microfinance became one of the most important international development policies to emerge over the last thirty years. ${ }^{2}$

Microfinance began to break with the traditional forms of economic development when Muhammad Yunus developed a project in Jobra, Bangladesh to foster economic growth and sustainability. By promoting small loans to farmers, he developed the idea that through individual entrepreneurship poverty reduction could occur, and would do so within a generation. With this in mind, he created the Grameen Bank in 1983, which allowed for the poor of

\footnotetext{
${ }^{2}$ Several scholars have focused on development and microfinance including: Amin (1999); Armendariz and Morduch (2010); Arun (2005); Barr (2004); Bateman (2012) "Role of Microfinance in Contemporary Rural Development"; Bateman (2011); Batman and Ha-Joon (2012); Brau and Woller (2004); Cunningham and MeyerStamer (2005); Elahi and Dnaopoulos (2004); Engel (2011); Ledgerwood, et. al. (2013); Littlefield et. al. (2003); Morduch (2000); Newby (1999); Otero (2000); Peet (2003); Rankin (2001); Robinson (2002); Sinclair (2012); Snow and Buss (2012); Taylor (2012); Weber (2002); Weber (2004) "Reconstituting the Third World"; Woller and Woodworth (2001).
} 
Bangladesh to have access to small loans through group lending; a mechanism that meant that for one loans each borrower in a group was responsible for each other and repaying the loan. This meant that the poor, despite having no collateral would have access to the capital they needed. He structured his credit program by instituting daily repayment programs of small amounts and group lending where each member had to be trained before given loans. Additionally, Grameen's mechanisms followed a loan length of a year, weekly repayment installments where repayment started one week after the loan start, and an interest rate of $20 \%$. $^{3}$ This is the traditional microcredit model that made the Bangladesh loan program successful. Microfinance in Yunus's vision was to foster economic growth from the bottom up. It was designed to give small business loans, as well as, banking and credit services to the poorer populations of a country in an effort to initiate sustainable livelihoods. In order to create sustainable livelihoods, Yunus focused on giving loans to women, who were seen as more likely to repay the loans, accept smaller amounts, and invest the income into their families creating economic sustainability for future generations. Seeing high repayment rates meant that the “targeting" of women for microfinance loans would become a key component of the best practices model, regardless of the social or political conditions in which women lived.

The idea of group lending further led to the growth of microfinance because it ensured a steadier repayment rate and allowed the idea of microfinance to grow and attract early funding from the International Fund of Agriculture and Development, the Ford Foundation, and the government of Bangladesh. Microfinance began the move out of Bangladesh and into the surrounding areas when other non-governmental organizations, like PRODEM (the original NGO and precursor to Banco Sol) saw the potential to eradicate poverty through financial

\footnotetext{
${ }^{3}$ Muhammad Yunus., Banker to the Poor (Public Affairs Books, 2003), 4.
} 
access. The Foundation for the Promotion and Development of Microenterprise (PRODEM) created the market for microcredit in Latin America and grew the industry from a loan only strategy to a large-scale financial services development program. Microfinance, therefore, is the "provision of a range of financial services in addition to credit, such as options for insurance schemes or opportunities to save." ${ }^{4}$ The microfinance revolution developed through the adoption of micro-credit and by the start of the new millennium microfinance has grown because of the spread of information and the extent to which some microfinance institutions have experienced success through mobilizing public savings and created greater access to capital markets. ${ }^{5}$

International best practices of microfinance can be traced back to the economic development policies of Robert McNamara during his term as president of the World Bank. In 1979, the Bank started to use "program loans to induce reforms" which was meant to be "structural adjustment lending to promote trade liberalization."6 The World Bank would aim their policies at structural problems. In 1980, the Bank set up the conditions under which loans would be made, and for the first time developing countries would be forced to "adjust their development patterns and economic structures."7 These structural adjustment policies dictated by the IMF and the World Bank in particular, did not promote long-term development and instead threw local industries into markets in which they could not compete and instead only fostered further declines into poverty. ${ }^{8}$ Under the guise of trade liberalization, the IMF and the World Bank imposed policies upon underdeveloped regions claiming that if they wanted help out of

\footnotetext{
${ }^{4}$ Weber., 363.

${ }^{5}$ Robinson., 49.

${ }^{6}$ Richard Peet., Unholy Trinity: The IMF, World Bank, and WTO. (London: Zed Books,2003), 121.

${ }^{7}$ Id.

${ }^{8}$ Peet., 140 .
} 
poverty that they must accept conditions for the loans, which focused on opening up their industries to the world market where they could not compete.

By the end of the twentieth century, a shift had been seen in poverty reduction strategies. They were now focused on "promoting real and operational partnership, based on shared responsibilities, and a systematic focus on the principles of policy coherence and governance."9 Microfinance's aim was to create "the virtuous cycle of economic advancement." ${ }^{10}$ However, the World Bank and the IMF in 1998 adopted Operational Policy 8.30, which incorporated microfinance minimalism into its poverty reduction strategy. ${ }^{11}$ Minimalism is a credit only approach to microfinance. This form of microfinance is meant only to dampen the resistance to trade liberalization policies at local levels. The microfinance minimalism that comes out of the World Bank and the IMF has gained recognition as "global best practices." 12 However, this is not necessarily truly the best practice for microfinance. The programs that they follow corresponds with the World Banks position on trade liberalization; in addition it devalues NGOs as potential intermediaries for the poor making them follow certain policies to be certified financial intermediaries, and ensure access to credit. ${ }^{13}$

Funding from the US government and World Bank saw the first moves to establish microfinance in Latin America (Chomsky, 2003; George and Sabelli, 1994). A number of microcredit programs began with the assistance of the Boston led advocacy body ACCION, which used funds from USAID (Bateman, 2013). Most of the MFIs established in the immediate wake of the Grameen Bank were deliberately structured to operate as NGOs with non-profit

\footnotetext{
${ }^{9}$ Heloise Weber., "The imposition of a global development architecture: the example of microcredit" Review of International Studies 28 (2002), 537.

${ }^{10}$ Ibid., 540.

${ }^{11}$ Ibid., 550.

12 Ibid., 552.

${ }^{13}$ Ibid., 552-553.
} 
status. In the early 1990s, the World Bank moved into the microfinance field through the International Finance Corporation, which created the Consulting Group to Assist the Poor (CGAP). Taking their cue from the international funding community, which microfinance institutions were dependent upon at this time, most international NGOs, bilateral development agencies, and developed countries governments began to shift their microfinance policies to fall in line with CGAP so that they could reassure continued funding and microfinance growth. The international development community now signaled to the microfinance industry that it would not help establish any other model of MFI and would seek to transform all existing MFIs into new MFI models. This new forced model of microfinance centered on best practices, would focus on more than group lending and small loans, and would instead have five key features: access to financial services, group lending through joint liability, requiring deposit savings in the bank, interest rates that took market value into consideration, and self-sufficiency within the institution. This transformed microfinance from an NGO donor driven model to a commercialized funding model that was more in line with neoliberal ideology and regular forprofit driven financial institutions.

In order for microfinance to become more sustainable, institutions began shifting to a best practices replication model rooted in neoliberal economic development theory. This new growth of neoliberal development focused microfinance programs meant that institutions were now focused on becoming for-profit ventures. This model of microfinance is driven by the World Bank, which focuses on economics and the ability to compete in the market place instead of letting countries protect their new industries. One of the core imperatives of neoliberalism is a firm belief in the financial self-sustainability of all institutions that operate in the economy and society. This shifting political stance was a driving force behind the shift from Yunus's 
microcredit model to a neoliberal microfinance model where interest rates had to be market based. This spurred the next big development in microfinance, global best practices.

The best practices model is based on eleven core principles: access to financial services, not just loans; microfinance is used to build assets; microfinance should be integrated into a countries mainstream financial system; microfinance should be self-sustaining; microfinance is about building permanent local financial institutions; other kinds of support may work better for the destitute that are without income for repayment; interest rates ceilings are harmful to MFIs; the government should enable financial services; donor funds should be used to build institutional capacity of financial providers; there is a shortage of institutions, funds should be used to build capacity; and microfinance institutions should measure their performance (based on loan repayment and cost recovery, and number and poverty level of clients being served). Taking their cue from the World Bank, most developed governments, bilateral development agencies and international NGOs shifted their microfinance support policy and programs towards this new approach. As such, this commercialized microfinance model was "firmly established as 'best practice' and the only acceptable definition of microfinance." ${ }^{\prime 4}$ The neoliberal policy making establishment began to build support for the commercialized replacement of Yunus microcredit with this new wave best practices model that followed neoliberal ideology by promoting free trade policies to foster economic development.

Microfinance institutions have changed the game of development economics and done so with negative effects. Microfinance in the last decade has changed the way development projects are approached with a shift towards neoliberal development theories. Micro-credit originally was thought of as a panacea for poverty alleviation, as well as a method for gender equality in

\footnotetext{
${ }^{14}$ Milford Bateman., "The Role of Microfinance in Contemporary Rural Development Finance Policy and Practice: Imposing Neoliberalism as 'Best Practice”” Journal of Agrarian Change 12, no. 4 (September 2012 ), 594.
} 
oppressive societies. However, reflecting on the rise of neoliberal development thinking, organizations promoting microfinance came to view it as a tool mainly for economic development and growth - and unlike Yunus, they do not consider it a cure for broader social ills and should not be considered so. In Latin America in particular, the arguments against inefficient states that stifle market forces has found resonance with the microfinance industry that promotes neoliberal reform of free market growth through lending initiatives. This project will look at the neoliberal institutional approach to explain how microfinance organizations perpetuate a best practices model that lead to mimicry within the field of microfinance. Current economic theory is not adequate to assess the current global economic system in underdeveloped and developing countries. The neoliberal institutional approach highlights how elites could assist the nation state in meeting its interests. ${ }^{15}$ The commitment to a multilateralism approach that neoliberal institutionalism has, highlights how economic elites continue to commit to those multilateral practices not because they are most efficient but because the practices themselves are affecting how elites define efficiency. ${ }^{16}$ The purpose of this project therefore is to show that microfinance institutions hold to these defined efficient practices, i.e. the best practices.

This dissertation will look at the impact that the best practices model has on microfinance institutions design. It will argue that MFIs can be more effective if they break from the best practices model because they then are able to adopt policies that work within their local political and cultural situations. As argued here, the reason for why this occurs falls into two different categories economic and socio-cultural. The first category addresses how the model of microfinance that is driven by the World Bank tends to focus on economics and the ability of

\footnotetext{
${ }^{15}$ Jennifer Sterling-Folker., "Competing Paradigms or Birds of a Feather? Constructivism and Neoliberal Institutionalism Compared” International Studies Quarterly 44, no. 1 (March 2000), 104.

${ }^{16}$ Ibid., 112.
} 
recipients to compete in the market place. This model stems from the World Bank's and the IMF's microfinance minimalism strategy, originating as an attempt to dampen the resistance to trade liberalization policies at local levels. ${ }^{17}$ This microfinance minimalism comes out of the World Bank and the IMF that has gained recognition as "global best practices." 18 The second, socio-cultural category addresses how MFIs have done little to understand the gender relations of their clients so their programs are not effectively tailored to such issues, which greatly reduce their impact. Furthermore, the targeting of women often creates gender distortions, as women are not given access to information about financial services.

Microfinance today tends to focus more on the international level rather than the local level, resulting in new problems because they are often constrained by policies that stem from tax regimes, resource allocation, and trade agreements. ${ }^{19}$ The problem is that global economic policies tend to be single-minded in that they focus exclusively on "global trade and attracting inward investment" and tend to ignore those local level political and socio-economic factors that create poverty. ${ }^{20}$ Microfinance today is heavily focused on the financial structures that surround it, who finances microfinance is also who defines what microfinance is and how it is constructed. Microfinance of today is greatly impacted by these trade regimes and political policy structures. The point of this project is to look at the policy structures that surround microfinance and show how the new microfinance is one of the financiers.

These policies are often adopted within a country with little regard to domestic social or political structures. Replication of microfinance has become an industry standard adopting best

\footnotetext{
${ }^{17}$ Heloise Weber, "The Imposition of a Global Development Architecture: The Example of Microcredit" Review of International Studies 28 (2002), 550.

${ }^{18}$ Ibid., 552.

${ }^{19}$ Id. Discredited by Les Newby "Sustainable Local Economic Development: A New Agenda for Action?" Local Environment 4, no. 1 (1999), 67.

${ }^{20}$ Les Newby, "Sustainable Local Economic Development: A New Agenda for Action?" Local Environment 4, no. 1 (1999), 67-69.
} 
practices in the belief that poverty alleviation is as simple as providing credit. Best practices are circulated by the consultative groups, such as policy communities to assist the poorest by the World Bank, the US Agency for International Development, the UN Development Program, and other key donors. ${ }^{21}$ Best practices is solely concerned with fostering the "financial sustainability of institutions that provide financial services" to the poor. ${ }^{22} \underline{\text { In this dissertation, I argue that }}$ governance for development needs to shift from a best practices model to what should be a "best fit" model. This means following an institutional design that is best suited for the community in which it operates. Essentially, for microfinance to be successful it needs to "question the ideological forces, vested interests, and political pressures that promote institutional mimicry" within the microfinance field. ${ }^{23}$ In order to move beyond this mimicry, organizations have to take into account the broader influence from the state, society and redefine what socially acceptable economic behavior is. ${ }^{24}$ Microfinance perpetuates mimicry through the agency of influential organizations and knowledge-bearing professions that diffuse their preferences through network ties linking those who adopt microfinance to those who develop best practices programs. ${ }^{25}$ This leads MFIs to follow the best practices method for institution programs instead of following the best fit model for development.

This dissertation will examine cases from Latin America because this is where microfinance is growing rapidly with a focus on Bolivia and Mexico. The cases used are Banco

${ }^{21}$ Jonathan Morduch., “The Microfinance Schism” World Development 28, no. 4: 617-618.

${ }^{22}$ Christopher Dunford., "In Search of 'Sound Practices' for Microfinance” Journal of Microfinance ESR Review 2, no. 1 (2000): 6.

${ }^{23}$ David Booth., "Governance for Development in Africa: Building on what Works" Africa Power and Politics Policy Brief 1 (April 2011): 1

${ }^{24}$ Christine Oliver., "Sustainable Competitve Advantage: Combining Institutional and Resource Based Views" Strategic Management Journal 18, no. 9 (1997): 697.

${ }^{25}$ Isin Guler, Mauro Guillen, and John Muir Macpherson., "Global Competition, Institutions, and the Diffusion of Organizational Practices: The International Spread of ISO 9000 Quality Certificates" Administrative Science Quarterly 47, no. 2 (June 2002): 211. 
Sol and Compartamos because they are considered to be the most successful MFIs in Latin America. Additionally, Banco Economico, and IDEPRO will be used as cases that were more flexible in following best practices. Additionally, Pro Mujer will be used as a comparison case as a control because it operates in both countries under consideration. All of these cases will stem from Latin America because their experiences in the region have greatly changed the way that microfinance is understood. These cases were chosen for their impact on the microfinance industry and to highlight those institutions that follow mimicked patterns. These cases were chosen to highlight some of the institutional designs that affect the best practices institutional design for MFIs.

Certain banks were chosen because of their shifts from the best practices model to a best fit model that would allow microfinance to have greater impacts among clientele; these include IDEPRO and Pro Mujer. These were chosen because they are NGO's with different objectives. Pro Mujer was chosen for this study because with entry into each new country they have refined and adapted their programs to meet the local needs and is used as a best fit model of microfinance. ${ }^{26}$ In summary, these cases where all chosen because they are formidable MFIs in the microfinance field and vary significantly with respect to their tight adherence to "best practices." Additionally, all of these cases were chosen for the differing degrees to which they follow the five basic aspects of best practices including; how they are set up, how they are regulated, lending type, and percentage of loans to women, and the poverty level of clients. Each of these cases was chosen because they add something to the story of how microfinance functions. Whether they adhere strictly to best practices or they diverge in significant ways, each case highlights how microfinance works in practice and how different models of microfinance

\footnotetext{
${ }^{26} \mathrm{http}: / /$ promujer.org/who-we-are/our-history/
} 
can have different outcomes for their counties economic development and more importantly their clients welfare.

This dissertation will use a case study approach using structured focused comparison. This will be used to assess the institutional design of MFIs in Bolivia and Mexico, and specifically, to see if a deviation from best practices results in more programs begin adopted that can have positive impacts for clients. In particular, it will offer initial evidence that MFIs departing from best practices contribute both economically and socially to its clients with (a) lower rates of indebtedness in its loans and (b) a wider array of community programs targeted at social and gender issues. Employing the method of structured focused comparison, this study will look at the different case studies and show the underlying theme of institutional mimicry that hinders microfinances' impacts. The different case studies will develop a broader explanation for the distorting effects that this hindrance can have by looking beyond the simple economic explanations and taking into account socio-cultural effects.

These case studies will highlight how institutional mimicry through best practices affects microfinance institutions' structure. In order to do this, institutional characteristics will be defined as the bank's financial structure primarily. The types of financial structures are NGOs, which are unregulated by government; full banks, which are regulated; and non-banking financial institutions, which are intermediaries allowing for loans but do not allow for savings and lack regulation from government. The clients of the non-regulated institutions have no protection from bank failure and traditionally rely on subsidies from the government to exist. Additionally, institutional sustainability will be defined through the institution's ability to remain stable despite economic shock and includes indicators like, deposits, debt to equity, number of borrowers, interest rates, loans disbursed, and outstanding loans. Institutional effectiveness is the 
MFIs ability to have positive economic outcomes for their clients and includes indicators like gender, household financing and consumption, as well as financial services and products offered, and development objectives that include gender empowerment increases, the ability of the MFI to introduce educational, health, and welfare reforms. This dissertation will highlight trends in the microfinance field by looking at institutional policy and industry standards. Finally, I will be looking at yearly report documents obtained from mixmarket.org on each bank to trace what policies they have adopted compared with financial data of clients to highlight the economic and social development impact that MFIs have depending on whether they follow best practices or deviate to a best fit model.

This dissertation consists of five more chapters. The next chapter is the literature review. It will cover the background concepts of microfinance and how it got to the best practices methodology. Additionally, it will cover the impact of institutional mimicry on poverty alleviation. Lastly, it will cover an assessment of the microfinance literature focusing specifically on neo-liberal development models, debt cycles, self-sufficiency, the economically active poor, gender targeting, local political practices, and social capital creation. Chapter three will cover the theoretical argument including the hypotheses. It will lay out the economic explanations and the socio-cultural explanations that impact the effectiveness of microfinance institutions. Chapter four will lay out the research design in detail. It explains how the structured focused will be done, the case study methodology, as well as the cases selected. Chapter five will present the empirical analysis. It will look at each of the cases and highlight how each adheres to or diverges from the best practices methodology, as well as, the impact that the lending practices and social programs by these institutions have on their clients. This will highlight how the best practices method of microfinance impacts clients. 
As argued in the dissertation's final chapter, its contribution to the debate on microfinance and poverty alleviation will be discussed by looking specifically at the impact that best practices has on institutional formation and therefore limits their outreach capabilities. When the World Bank looked into this in 2008, they concluded that poverty alleviation was nothing more than the use of credit to positively impact household welfare. ${ }^{27}$ Poverty alleviation by MFIs is defined by three key indicators: establishing permanent institutions that can withstand economic shocks; engaging in practices that help the poor by reducing interest rates, by not focusing solely on repayment, by providing needed financial services, and by benefiting the women that they make loans to through social welfare programs; and finally, poverty alleviation should provide additional programs by which clients can maintain food, shelter, health and family planning services, employment, and education. This is what poverty alleviation should look like. However, this project argues that because of institutional mimicry and the adherence to the best practices model, microfinance does not focus enough on poverty alleviation programs but instead focuses too narrowly on economic outcomes and loan repayment.

Microfinance in the new millennium should focus on finding alternative funding sources from internal structures such as existing banks, as well as working with aid agencies like NGOs to determine the best target population. The reformulated institutions can then work toward reducing corruption and making stronger portfolios among their clients. Interestingly, with funding that is not dependent entirely on government, microfinance programs would therefore be able to work in post-conflict societies, or societies that are in the midst of rebuilding government structures. This approach would bring about a new understanding of the way development

\footnotetext{
${ }^{27}$ Vivienne Walt “Does Microfinance Really Work? A New Book Says No” Time (Jan 2012), http://content.time.com/time/world/article/0,8599,2103831,00.html
} 
politics and sustainability projects operate focusing on the local market structure as a step up program into the global economy. 


\section{Chapter Two}

\section{Literature Review: Origins and Critical Assessments of MFIs}

The literature review for this dissertation is divided into two general sections. The first section introduces the reader to topic of microfinancing by overviewing the origins and evolution of this phenomenon. Considered in this discussion are questions such as: what microfinance is and how it differs from microcredit, what best practices include, how poverty alleviation and elimination are measured, and what institutional mimicry is and how it takes shape in the microfinance industry? The second section of the literature review covers the critiques and assessments of microfinancing, including economic critiques, socio-cultural critiques, and political critiques. As such, it has three subsections. The first of these examines economic critiques focusing on access to capital and market forces, including, the impacts that debt cycles, self-sufficiency, and economically active poor have on poverty alleviation. The second subsection deals with socio-cultural critiques focusing on the impacts of traditional social structures including, issues of gender targeting, and the disregard for local social conditions. The third subsection will highlight the political critiques of microfinance; including, local political practices that hinder microfinance and the role of international influence in microfinance. Finally, this chapter will conclude with a summary of themes and arguments, highlighting the overall argument of this dissertation that best fit models of microfinance are more successful in creating poverty alleviation than best practices.

\section{The Origins and Evolution of Microfinancing}

Because this dissertation aims to explore the underlying structural differences in microfinance models, it is of importance to note how the different models came to be and what microfinance is today. Microfinance was developed out of the micro-credit schemes and was 
looked at as a positive step forward in creating sustainable financial assistance to the poor. Microfinance is therefore, is a fully encompassing financial service that involves not just giving out low collateral loans but also in fostering savings and providing financial training to recipients. Microfinance was seen as a step up from the loan only micro-credit schemes because it was to provide recipients with not only the financial training to use the loans appropriately but also a savings mechanism so they could deal with economic shocks. The transition to the full microfinance model came after the collapse of several micro-credit schemes after funding for those programs stopped or fell through because it was predominately from governmental subsides or international aid programs and NGOs. The following section is divided in two parts to further address how microfinance transpired, including not only what best practices are but also how they came to dominate the microfinance field. The first will illustrate what microfinance is by looking at its origins and how microcredit became a more encompassing model of microfinance known as best practices. Best practices encompass financial services to the poor, not just loans. The second section addresses how microfinance became the development policy of choice in Latin America. It will specifically highlight how microfinance has diffused throughout Latin America through institutional mimicry. All of these things taken together make-up how microfinance institutions design themselves in order to maintain support from the World Bank, and as such have become the only model for microfinance that is supported.

\section{From Yunus's Microcredit to Commercialized Microfinance}

Microcredit began in 1976, when Muhammad Yunus piloted a research project to study how to design a credit program to bring credit to rural farmers in Bengali, Bangladesh. This method of fostering development hinged on the use of small loans to the rural poor, and the loans 
would be used to create sustainable farming methods to raise the living standard. "Microcredit" programs began to gain a foothold as an economic development policy in the 1980 s when the World Bank began to focus on microcredit for poverty reduction. However, micro-loans were viewed as incomplete programs that often failed to recognize the financial sustainability that they attempted to foster. Programs for the new millennium appropriately focused on microfinance programs that aimed to foster development through lending and developing financial skills, manage growth and generate sustainable systems that deliver quality financial services.

Microfinance is simply a range of financial services, including loans, as well as insurance programs and savings opportunities. ${ }^{28}$ There are three fundamental differences between microcredit and microfinance. The first being the role of profit motive, whereby micro-credit programs run by NGOs and non-profits are most concerned with poverty alleviation and as such are not concerned with profit. Microfinance on the other hand is a "for-profit venture." 29 The second fundamental difference concerns the way the programs are financed. Micro-credit organizations rely on subsidies and depend on external finance, where microfinance programs are expected to become self-sustaining. ${ }^{30}$ The third and biggest difference between the micro-credit model and the new microfinance models involves the actual lending methods. Traditional programs would use group lending, while the new programs have revolutionized the group lending method to include "group-lending contracts" and loans to individuals. ${ }^{31}$

\footnotetext{
${ }^{28}$ Heloise Weber, “The 'New Economy' and Social Risk: Banking on the Poor?” Review of International Political Economy 11, no. 2 (2004), 363.

${ }^{29}$ Khandakar Q. Elahi and M.L. Rahman, "Microcredit and Microfinance: Functional and Conceptual Differences" Development in Practice 16, no. 5 (2006), 479.

${ }^{30} \mathrm{Id}$.

${ }^{31}$ Marquerite Robinson, The Microfinance Revolution: Sustainable Finance for the Poor (World Bank and Open Society Institute: 2001), 285. The idea of group lending contracts have started a revolutionized approach to the field and many economic theorists have been extremely interested in this method.
} 
Elahi and Rahman (2006) address the links between microcredit and microfinance. ${ }^{32}$ They address how microcredit has become the foundation of microfinance and leading to a second revolution in microfinance. The first revolution being the introduction of microcredit, which focused mainly on loan distribution and recovery; while the second revolution of microfinance focused on providing a full range of financial services. This is the main difference between microcredit and microfinance. Woller (2002) further highlights this move by looking at the possibility to provide financial services to the poor. Woller separates himself from other scholars on this point by arguing the microfinance needs a second revolution in order to fulfill the promises it makes. Woller's main contribution here is to argue that operational policies of microfinance institutions focus too heavily on the credit portion and therefore create vulnerability and prevent the very poor population from participating. By not participating these segments no longer have any access to financial services, including savings.

The case of Compartamos in Mexico is important in explaining how microfinance's best practices developed. This MFI has drastically changed the landscape of microfinance by becoming a publicly traded organization that laid the foundation for a model of not only a sustainable institution, but also more importantly it proved that the microfinance industry could be profitable for investors. In 2007, Compartamos was put up for Initial Public Offering (IPO) entering the stock market. ${ }^{33}$ When Compartamos entered the public market, it saw its investors and managers make millions of dollars while their clients were charged up to $195 \%$ interest rates on their microloans. ${ }^{34}$ The commercialization of microfinance has ultimately changed the face of

\footnotetext{
${ }^{32}$ Khandakar Quadrat-I Elahi and M. Lutfor Rahman, "Micro-Credit and Micro-Finance: Functional and Conceptual Differences" Development in Practice 16, no. 5 (August 2006): 476-482.

${ }^{33}$ Milford Bateman., "The Age of Microfinance: Destroying Latin American Economies from the Bottom Up” OFSE Working Project 39 (May 2013): 5.

${ }^{34}$ Id.
} 
the microfinance mission. The MFIs were no longer focused on social missions but instead were concerned with financial sustainability and growth. The IPO offering of Compartamos saw high profile MFIs begin to follow the Compartamos model, which includes microcredit, savings, and insurance policies, all while maintaining self-sufficiency through high interest rates.

Compartamos's operating model is a for-profit model that is the epitome of best practices in the microfinance industry. In sum, the Compartamos case is important to look at because it started the trend of commercializing microfinance. In addition, it changed the focus of microfinance from its social mission to one of economic sustainability, and therefore contributed to the overall restructuring of microfinance institutions around the world.

\section{The Diffusion of Microfinance in Latin America}

Microfinance in Latin America started relatively early, around the same time as the Grameen Bank in Bangladesh. In the 1970s, informal organizations were lending small amounts to low income individuals. These early loans were not in the same vain as the microfinance in Bangladesh in that the loans were given to men who already had small business and therefore had some collateral base to repay the loan. ${ }^{35}$ These early lending programs were developed in the vain of Raul Prebisch, the Chief Economist at the UN Economic Commission for Latin America, and were to focus on replacing imports with local produced manufactured goods. ${ }^{36}$ In 1975 , the UN Women's Conference identified access to credit as a major obstacle to escaping poverty, after acknowledging Yunus' work. Coinciding with the UN World Conference of the International Women's Year the conference defined a plan of action for the implementation of a

\footnotetext{
35 Tricia Olsen., "New Actors in Microfinance Lending: The Role of Regulation and Competition in Latin America” Prospectives on Global Development and Technology 9 (2010), 503.

${ }^{36}$ Bateman (2013), 9.
} 
set of guidelines for the advancement of women, of which microfinance was a major plan component.

Microcredit quickly assumed as much importance in Bolivia as in Bangladesh thanks to pioneering institutions like PRODEM, established to provide microloans in the city of La Paz. Most of the MFIs established in the immediate wake of the Grameen Bank were deliberately structured to operate as NGOs with non-profit status. In addition, governments or international funding initially funded the majority. The prevailing logic at the time was that since the Grameen Bank had shown high repayment rates a possibility, little ongoing funding would be needed to maintain an MFI. Since a key feature of Yunus' microcredit was low interest rates, to give the poor financial space to benefit and reinvest the loan, it began to become clear that it was not possible to keep interest rates low and maintain a self-sufficient MFI. Morduch (1999), Seibel (2005), and Jackelen (1989) among others noted that the Grameen Bank model would not be self-sufficient and that repayment rates were actually lower than claimed which meant that extensive donor funds and subsides would be needed to maintain this model of microfinance. With the shifting economic theories to neoliberalism, financial self-sustainability of all institutions that operate in the economy became an imperative resulting in the shift to the commercialized microfinance model in Latin America.

The first major breakthrough came in Bolivia when the World Bank and USAID began to look at restructuring the Bolivian economy to fall more in line with neoliberal policies by recasting the subsidy driven Grameen Bank style microfinance model to a commercially driven one. This was done by transforming the NGO PRODEM to Banco Sol. Advising on the Banco Sol transformation was the US based ACCION that was also working on many microfinance programs in South and Central America under contract to USAID. Rhyne (2001) highlighted 
how the transformation to Banco Sol was the effective way for commercialize microfinance to expand around the globe. Bateman (2013), Lora and Marquez (1998), and Helwege and Birch (2007) show how microfinance defused through Latin America through various programs developed by FINCA, USAID, and IDB in Brazil, Bolivia, Columbia and Mexico, all stemming from the idea that the expansion of the informal sector would be best way for the continent to reach development goals. Bateman (2013) argues that the microfinance model was thoroughly embedded in Latin America's economy and financial system by the 1990s as significant resources began to shift to microfinance. Additionally, Bateman (2013) highlights the importance of the US and then World Bank funding for developing the microfinance sector in Latin America. ${ }^{37}$ Christen (2000) estimated that the size of the Bolivian microfinance market in 1999 as having disbursed nearly 380,000 microloans with a market penetration rate of $163 \% .{ }^{38}$ This massive growth of the microfinance industry in Bolivia led to further dispersion of microfinance through International Finance and World Bank funding and support into Peru, Columbia, Mexico and throughout the region. Microfinance began to be seen as a successful development model that supported neoliberal commitments, further pushing it into the economies of Latin America.

\section{Growing Issues in MFIs: Questions of Best Practices and Institutional Mimicry}

The literature has addressed many critiques of microfinance in order to better understand how microfinance has grown out of Yunus' model. It is important to look at what best practices are and how institutional mimicry has perpetuated a new model of microfinance. Mimicry in microfinance grew out of Compartamos' move to an IPO. This resulted in a multitude of

\footnotetext{
${ }^{37}$ Bateman (2013), 11-13.

${ }^{38}$ Robert Peck Christen (2000)., "Commercialization and Mission Drift: The Transformation of Microfinance in Latin America” CGAP Occasional Paper no. 5 Washington DC (January), 24.
} 
commercialized microfinance institutions charging high interest rates, and the British government then funded a systematic review to look at the impact of microfinance. While they were hoping to find support for microfinance, they instead found that despite thirty years of operation, there was little if any evidence to support the positive claims of MFIs that they created poverty reduction. ${ }^{39}$ The research team found that positive conclusions were only found through inappropriate methodologies and faulty impact evaluations; they further concluded that the microfinance model was "under existential threat." 40 The review concluded that there was no evidence to support poverty reduction claims that have been a driving force behind microfinance for the past thirty years. The study found that there were fundamental flaws within the microfinance model itself that made it an "anti-development intervention." ${ }^{41}$ This is important because the vast majority of microfinance models are built upon the best practices model. This study highlights that the mimicry of this model is what hinders the effectiveness of microfinance institutions. The following section will discuss best practices and institutional mimicry in more detail, as well as how poverty alleviation is defined and related to the best practices model of microfinance.

Best Practices. MFIs have established a set of best practices for instituting and running such projects. Although this began with the Mohamad Yunus microcredit model in Bangladesh, the major differences between Yunus' microcredit model and the best practices microfinance model focused on lending practices. The new microfinance model began looking at these institutions to "seek to establish permanent institutions and sustainable systems that deliver quality financial services for clients (not beneficiaries)" and in doing so began to create a best

\footnotetext{
${ }^{39}$ Bateman (2013), 6.

${ }^{40} \mathrm{Id}$.

${ }^{41}$ Bateman (2013), 6.
} 
practices model for microfinance. ${ }^{42}$ The best practices model also encouraged the growth of savings before loans to help spur capital that is necessary for financial stability (Wright, G., 2000; Yousif, et al., 2013; Arora, 2012; Bateman, 2013, 2012, 2010; Morduch, 2000). Bateman (2010) showed that the best practices model of microfinance became the international communities' poverty reduction policy of choice." 43

As noted, the best practices model stems from the microcredit model founded by the Grameen Bank in Bangladesh in 1983 (Yunus, 2011, 2003). Their model had five key features: lends only to the very poor, deals with creditors in groups, requires creditors to deposit savings in the bank, uses peer pressure of the group to ensure loan repayment, and requires good credit standing to secure subsequent loans. ${ }^{44}$ The program was structured by instituting daily repayment programs of small amounts and using group lending. ${ }^{45}$ This traditional microcredit model made the Bangladesh loan program successful.

Today microfinance stems from the World Bank's move into the microfinance field by creating the Consultative Group to Assist the Poor (CGAP). CGAP produced the 'Pink Book' to explain the core principles around which all microfinance programs now had to be built. ${ }^{46}$ This new wave microfinance model established the best practices for microfinance (Aggarwall, 2013; Ahlin, Lin, and Maio, 2011; Aitken, 2013, 2010; Bhatt and Tang, 2001; CGAP, 2006; Dacin, 1997; Dunford, 2000; Gine, et al., 2010; Rahman, et al. 2012; Sinclair, 2012). CGAP and the World Bank set out the best practices model basing it on eleven core principles: access to

\footnotetext{
${ }^{42}$ Graham Wright, Microfinance Systems: Designing Quality Financial Services for the Poor (Zed Books: 2000), 129.

${ }^{43}$ Milford Bateman, Why Doesn't Microfinance Work?: The Destructive Rise of Local Neoliberalism (Zed Books: 2010), 19.

${ }^{44}$ Douglas Snow, and Terry Buss., "Development and the Role of Microcredit" Policy Studies Journal 29, no2 (2001), 3 .

${ }^{45}$ Muhammad Yunus., Banker to the Poor (Public Affairs Books, 2003), 4.

${ }^{46}$ Milford Bateman., Why Doesn't Microfinance Work?: The Destructive Rise of Local Neoliberalism (Zed Books, 2010), 30
} 
financial services; assets building; integration in the mainstream financial system; selfsustaining; building permanent local financial institutions; other kinds of support for the destitute; not capping interest rates; the government should enable financial services; capacity building; and microfinance should measure its performance (based on loan repayment and cost recovery, and number and poverty level of clients being served) ${ }^{47}$ Bateman (2010) showed that developed governments, bilateral development agencies, and international NGOs shifted their microfinance support policy and programs towards the World Bank approach. ${ }^{48}$ Existing literature on microfinance has consistently shown that the most prevalent model of microfinance is the best practices model; however, this literature does not question best practices in an institutional design, whereas this dissertation hopes to fill this gap by looking at how the institutional design of microfinance impacts poverty alleviation outcomes. ${ }^{49}$

There is literature that has shown that when using the best practices model problems arise, but it does not propose an alternative whereas this dissertation proposes a best fit model. The literature focuses on four main themes in critiquing microfinance; over indebtedness; outreach and client targeting; gender empowerment; and the role of the government (Hilton 2012; Woller, 2007; Johnson; 2005; De La Torre, Gine, and Vishwanath, 2011). Ditcher (2007) argued that the evidence for the alleviation of poverty within the best practices model of microfinance was "largely a mirage." ${ }^{50}$ Bateman (2010) argued that the best practices model at the heart of microfinance "thoroughly disempowered individuals." ${ }^{51}$ Ellerman (2007) additionally argued that the best practices model sustained "programmes that [had] little if any

${ }^{47}$ CGAP Pink Book., 2006., i.

${ }^{48}$ Bateman (2010), 30.

${ }^{49}$ Augsburg and Fouillet, 2010; Bateman, 2013, 2012; Bayulgen, 2008; Bedecarrates, et al., 2012; Lotzenkirchen and Welstrofer, 2012; Malamut, 2006; Ramani, 2007; Sinclair, 2012

${ }^{50}$ Bateman (2010), 42.

${ }^{51}$ Bateman (2010), 46. 
development effectiveness." 52 In 2009, the World Bank even concluded in the PREM Moving out of Poverty study that microfinance will only "help the poor subsist from day to day" and that the poor felt that they lacked the "linkages [that] are crucial in helping them escape poverty." 53

Institutional Mimicry. The implication of best practices is that it creates a situation where microfinance is adopted into a multitude of locations without regard to the local political and social conditions. This is mimicry. Institutional mimicry stems from the policy sciences that looked at policy transfer. Policy transfer occurs when countries come up against a policy need and therefore look to other countries that have had the same set of circumstances. One of the most pervasive policy problems has to do with poverty alleviation. Policy communities are an important dynamic in the policy transfer of microfinance. They include organizations such as the MicroCredit Summit Preparatory Committee, the Grameen Trust/CASHPOR, and the Foundation for Development Co-operation (FDC), along with CGAP. The increasing number of organizations like these allows for quick start up of tested models and systems, however, these models often require substantial modification to make them suitable for local conditions. Organizations such as those found within the policy communities do not possess the necessary knowledge to modify the microfinance policies adequately. Replication of this kind is dangerous because these policy communities are consultants, lenders, or donors who design and recommend systems that they themselves do not fully understand resulting in incomplete or blurred blueprints that center the focus on credit, which makes clients reliant on permanent access to these services. This means that the policies focus too narrowly on the access to credit

\footnotetext{
${ }^{52}$ David Ellerman, "Microfinance: Some Conceptual and Methodological Problems" in Thomas Dichter and Malcolm Harper, eds., What's Wrong with Microfinance? (London: Practical Action Publishers: 2007 ), 155.

${ }^{53}$ News Release no. 2009/240/PREM, World Bank, 11 March 2009.
} 
portion of the policy and neglect the services that should go with them like educational, business, and savings portions of the programs.

What is most important here is the aspect of copying. When it comes to policy copying, this is replication, or isomorphic mimicry. Isomorphic mimicry is not a new concept and has roots in biology as the animal kingdom has many instances of camouflage that mimics other animals for survival. Then political scientists began to look at structural isomorphism of states in the global system. ${ }^{54}$ Organizational policy sciences then picked up the mimicry idea and focused on how isomorphic institutions were set up around the world to look like successful organizations. ${ }^{55}$ From these foundations, I have defined institutional mimicry as a form of policy copying where institutions mimic successful institutions by actually copying their structures. In the case of microfinance, this refers to the persistent copying of best practices modeling of microfinance. This mimicry provides "less scope for learning" and results in a "one-size-fits-all approach" to policy reform, which are best practices.

The most important literature on institutional mimicry is DiMaggio and Powell's The Iron Cage Revisited: Institutional Isomorphism and Collective Rationality in Organizational Fields. DiMaggio and Powell (1983) argued that capitalist enterprises are models of bureaucratic organizations, and that this bureaucratization forms out of structuration. ${ }^{56}$ Additionally, they highlight the fact that organizations compete for resources and customers as well as, political power and institutional legitimacy. DiMaggio and Powell further argue that mimetic institutional

\footnotetext{
54 John Meyer et al., 1997.

${ }^{55}$ Matt Andrews., Lant Pritchett, and Michael Woolcock., Building State Capability: Evidence, Analysis, Action (Oxford University Press, 2017), 31.

${ }^{56}$ DiMaggio and Powell, 147.
} 
isomorphism is created when the environment creates uncertainty, and therefore organizations may model themselves on other organizations. ${ }^{57}$

DiMaggio and Powell highlight how other organizational modeling structures do not account for mimicry arguing that organizations tend to "model themselves after similar organizations...that they perceive to be more legitimate or successful." 58 They argue that certain kinds of structural arrangements can more likely be attributed to mimicry processes rather than other models. They argue that organizations with disputed or ambiguous goals tend to model themselves after organizations they perceive as successful. These organizations do this because they are reliant on other organizations for legitimacy. Such organizations would find it to their advantage to meet expectations of important constituencies about how they should be designed and run. ${ }^{59}$ Additionally, the discount innovation through modeling by showing that innovations are often adopted to enhance their legitimacy. ${ }^{60}$ Importantly DiMaggio and Powell argue that mimicry is the effect of several characteristics of organizational fields. They argue that the best indicator of isomorphic mimicry is a decrease in variation and diversity. ${ }^{61}$ The microfinance industry operates on the assumption that microfinance can reduce poverty and therefore the goal must be to extend microfinance to as many people as possible. ${ }^{62}$ The commercialized microfinance industry has resulted from international capital being drawn toward profitable MFIs like Compartamos. ${ }^{63}$ As international capital is drawn toward one model type of microfinance mimicry among other microfinance institutions is bound to occur.

\footnotetext{
${ }^{57}$ Ibid., 151.

${ }^{58}$ Dimaggio and Powell., 152.

59 Ibid., 155.

${ }^{60}$ Ibid., 152.

${ }^{61}$ Ibid., 155.

62 Bateman, Confronting Microfinance., 52.

${ }^{63}$ Ibid., 57.
} 
Through the experimentation with micro-credit and micro-finance, MFIs have established a set of best practices for instituting and running such projects. This began with the Mohamad Yunus microcredit model in Bangladesh. The major differences between Yunus' microcredit model and today's microfinance model lies within the lending practices. Microcredit focuses on loans given through small group formation or rotating member repayment groups; however, microfinance focuses on single individual lending (although they do group lending as well, formulated within the joint liability framework); additionally, microfinance focuses on the savings and full range financial services as well as lending). The new microfinance model began looking at these institutions to "seek to establish permanent institutions and sustainable systems that deliver quality financial services for clients (not beneficiaries)" and in doing so began to create a best practices model for microfinance.${ }^{64}$ The best practices model also encouraged the growth of savings before loans to help spur capital that is necessary for financial stability (Wright, 2000; Yousif, et al., 2013; Arora, 2012; Bateman, 2013, 2012, 2010; Morduch, 2000). Bateman (2010) showed that the "microfinance model became the international development community's poverty reduction policy and programme of choice. ${ }^{" 65} \mathrm{He}$ argues that this model of microfinance became a "behemoth" that was based upon on a "flawed understanding of basic economic principles" and that the new model of microfinance diverted so much from the Yunus Bangladesh model that it "abandoned almost all of the core principles upon which [Yunus] had established the original Grameen Bank model."

Poverty Alleviation. A major theme in the microfinance literature is its ability to reduce poverty. There are two approaches in the literature on microfinance. One is considered an

\footnotetext{
${ }^{64}$ Wright., 129.

${ }^{65}$ Bateman., 2010., 19.

${ }^{66}$ Bateman, 2010, 19.
} 
“institutionalist perspective" that highlights microfinances commitment to the "neoliberal/globalization agenda" and focuses on financial self-sufficiency, while the other approach is a "welfarist" approach that focuses on the sectors ability to realize its mission of poverty reduction. ${ }^{67}$ There is a major debate in the literature between the two approaches but ultimately the depth of outreach and support practices that allow MFIs to serve the very poor and alleviate poverty are widely cited as the original and main goal of microfinance. As such, this project will look at microfinance from the welfarist approach because the issue of whether or not microfinance really does alleviate poverty is at the core of all arguments in the literature on microfinance and as such casts my dependent variable in this light.

An important thing about the literature on poverty alleviation is that the different studies address the different ways in which poverty alleviation can be assessed. Poverty alleviation is the dependent variable because it is the key indicator of the effectiveness of MFIs. Poverty alleviation is defined in the literature by three key indicators: MFIs should establish permanent institutions that can withstand economic shocks; MFIs should engage in practices that help the poor by loaning money at reasonable interest rates, by not pressuring clients for repayment, by providing financial services, and by benefiting the women that they make loans to; and finally, poverty alleviation should improve the quality of life of clients by providing means by which they can maintain food, shelter, health and family planning services, employment, and education. ${ }^{68}$ This is what poverty alleviation should look like and it is what MFIs should strive to accomplish. However, this project argues that because of institutional mimicry the adherence to the best practices model does not result in alleviating poverty but instead it results in

${ }^{67}$ Bison, Dalton, and Wilson., 2012. "The Social Construction of the Microfinance Industry: A Comparison of Donor and Recipient Perspectives" Cosmopolitan Civil Societies Journal 4, no. 2, 62-63.

${ }^{68}$ Robinson., 2001. 
overindebtedness, baring the very poor from the financial services that they need through client targeting practices, creates more problems for women as they are the ones responsible for the debt of the microfinance loan, and spurs corruption and soaring interest rates as the domestic political systems frame the interactions between the MFIs and the state.

By 2009 , the best practices model began to be criticized for not creating any positive gains in poverty alleviation (Bateman 2010). This was due in part because of the first two randomized control trials in the microfinance sector, which found a lack of positive gains in poverty levels for clients. Banarjee, et al. (2009), Karlan, and Zinman (2009) both raised doubts about the "causal link between microfinance participation and poverty reduction." 69 Karlan and Zinman (2009) actually found that access to microfinance actually resulted in a decline in "subjective well-being" highlighting the argument that microfinance does not have a significant impact on poverty alleviation. ${ }^{70}$ Bateman and Chang (2012) argue that the microfinance model perpetuate by best practices was a barrier to "sustainable economic and social development, and also to poverty reduction." ${ }^{, 71}$ Sinclair (2012) argues that there tends to be a gap between theory and the practice of microfinance. Furthermore, he argues that no substantial reduction in poverty can be "reasonably attributed" to microfinance. ${ }^{72}$ The literature on microfinance and poverty alleviation continually indicates MFIs have problems with reducing poverty (Arunachalam 2011; Karim 2011; Klas 2011; Khandker, 2005; Duvendack and Palmer-Jones 2011; Thrikawala, Locke, and Reddy, 2013; Vijaya and Veerendrakumar, 2013).

\footnotetext{
${ }^{69}$ Duvendack and Palmer Jones, 2011, "High Noon for Microfinance Impact Evaluations: Re-Investigating the Evidence from Bangladesh.” Munich Personal RePEc Working Paper no 27902 (January), 5.

${ }^{70}$ Karlan and Zinman., 2009, 16.

${ }^{71}$ Bateman and Chang., 2012, "Microfinance and the Illusion of Development: From Hubris to Nemesis in Thirty Years" World Economic Review 1, 13.

${ }^{72}$ Sinclair., 2012, Microfinance Heretic, 220.
} 
Batman (2012) highlighted the idea that microfinance was popular because it was the "political serviceability of the microfinance concept that catapulted it into becoming the international development agencies single most important policy." ${ }^{.73}$ Additionally, the World Bank (2008) looked at microfinance and poverty reduction concluding that more research is needed; importantly they defined poverty alleviation in relation to microfinance as the use of credit to impact household welfare positively. Walt (2012) found that that impact of microfinance on poverty of clients was zero. ${ }^{74}$

Karlan (2001) found that assessments of microfinance institutions often omitted former clients creating a survivorship bias that overstates the program's success. ${ }^{75}$ Armendariz and Morduch (2010) showed that evidence on statistical impacts has been mixed at best, and that there is no robust study that shows strong impacts, instead most of them show the possibility of positive impacts. ${ }^{76}$ Coleman (1999) found that in the average microfinance program in Thailand, the impact was not significantly different from zero after controlling for member selection and program placement. ${ }^{77}$ Snodgrass and Sebstad (2002) found that in Peru, Zimbabwe, and India there were no measurable increases in average incomes of participants. Additionally, they found that in Peru there were actually negative impacts in the ability to cope with shocks. Nghiem, Coelli, and Rao (2012) looked at the impact of microfinance in Vietnam. They used quasiexperimental survey structure in Vietnam and found no significant effect of participation on

\footnotetext{
${ }^{73}$ Bateman., 2012, 594-595.

${ }^{74}$ Vivienne Walt "Does Microfinance Really Work? A New Book Says No" Time (Jan 2012), http://content.time.com/time/world/article/0,8599,2103831,00.html

${ }^{75}$ Dean Karlan., 'Microfinance Impact Assessments: The Perils of Using New Members as a Control Group" Journal of Microfinance 3 (2001): 75-85.

${ }^{76}$ Beatriz Armendariz and Jonathan Morduch, The Economics of Microfinance (Cambridge Publishing, 2010): 247.

${ }^{77}$ Brett Coleman., "The Impact of Group Lending in Northeast Thailand" Journal of Development Economics 60 (1999): 105.
} 
household welfare. ${ }^{78}$ Having discussed how microfinance addresses the issue of poverty alleviation, the next section discusses how institutional mimicry impacts microfinances ability to achieve income growth that would alleviate poverty.

\section{Critiques of Microfinance: Economic, Socio-Cultural, and Political Perspectives}

A substantial literature has emerged that critiques the effectiveness of microfinance programs. The field of microfinance when attempting to measure how well a program works focuses mostly on impact assessments, which tend to be donor driven and used to justifying funding. This leads to profitability and sustainability standards through which success is ultimately measured and defined. Measuring success in this manner allowed practitioners, who received funding from outside sources (not from loan repayment but from NGO/IGO/or Governments) to "manipulate numerous (legitimate) accounting procedures to ensure that published [repayment] rates remained high.” Herms and Lensink (2007) highlight the problems with measuring the impact of microfinance in this manner. They argue that without measuring education and health and infrastructure it is "unclear whether microfinance contributes to a reduction in poverty." Kaboski and Townsend (2005) add to our understanding of how MFIs typically are measuring impact by looking at village-level MFIs in Thailand. They found that "failed" institutions appeared in their data making the argument for needed exogenous variation, which they do not cover, but instead argue that it is a "peculiarity of the Thai political environment."79 They do not address this issue further, and therefore like many MFI impact assessments they tend to focus too narrowly on impact measurements and do not flush out what they mean by impact nor do they provide a definition for what failure means. By measuring the

\footnotetext{
${ }^{78}$ Son Nghiem, Time Coelli, and Prasada Roa, “Assessing the Welfare Effects of Microfinance in Vietnam: Empirical Results from a Quasi-Experimental Survey” The Journal of Development Studies 48, no. 5 (2012): 624

${ }^{79}$ Joseph Kaboski, and Robet Townsend., "Policies and Impact: An Analysis of Village-Level Microfinance Institutions" Journal of European Economic Association 3, no. 1 (March, 2005), 4.
} 
impact of MFIs in this manner studies tend to completely overlook failed MFIs and focus narrowly on successful ones, and therefore perpetuate a culture of mimicry in the microfinance field.

This chapter seeks to bring together the literature by focusing on economic, sociocultural, and political factors all together to highlight a deeper understanding of microfinance overall impact in reducing poverty. At issue therefore, is the question of whether or not the best practices model based on the Bangladesh experience is effective for the wider variety of developing country settings to which is has been applied. The widespread application of this standard model in diverse setting is what I label "institutional mimicry." This chapter will consider three sets of factors that might distort or otherwise undercut the effective implementation of otherwise well-intentioned development aid. The first set of factors include economic critiques that focus on MFIs commitment to neoliberal development practices. The second set of factors include socio-cultural critiques that focus on the commitments to lending to women only through gender targeting practices, and the influence that social capital creation has on the perpetuation of no collateral lending to the poor. Finally, the third set of critiques focuses on political factors that include how local political practices can lead to misuse of loans, and how the influence of international organizations perpetuates only a single "best practices" model of microfinance.

\section{Economic Critiques of Microfinance}

As such, this section covers the economic logic of microfinance and best practices as MFIs structures are tied to market oriented ideologies with a focus on an ability to compete in the market place as a development strategy. The economic factors addressed cover issues of 
neoliberal market orientation that MFIs follow issues of debt cycles, self-sufficiency, as well as the impact of the economically active poor clients.

Commitment to Neo-Liberal Development Models. Neoliberalism as a theory focuses on “deregulation, privatization, and a withdrawal of the state from many areas of social provision." 80 Harvey (2005) and Ong (2006) argue that when it comes to microfinance and neoliberalist economic policies, the models of microfinance based on best practices "subjects citizens to act in accordance with the market principle of discipline, efficiency, and competitiveness." ${ }^{\prime 1}$ When coupled with conditional funding from the World Bank and other international organizations, microfinance reinforces neoliberal development models instead of adopting new models for development and poverty alleviation. ${ }^{82}$ Hardy, Holden, and Prokopenko (2003) find that the form of donor funding support (either startup or continuous funding) for the MFI significantly affects the performance of the institutions and the value that it has to society. They argue that ongoing support is needed but the support should be designed to limit aiddependency traps. ${ }^{83}$ Aid-dependency weakens incentives for sustainability while suppressing competition for commercially driven development programs. Hardy, Holden, Prokopenki (2003) further argue that support for MFIs should be given as a start-up grant and not continuously. This would allow for a variety of experiments on how to start microfinance programs while recognizing that a portion of such experiments would fail. The authors balance that failure by arguing that such innovation would allow several institutions to operate within an area so that failure of one MFI does not leave the poor without services. ${ }^{84}$ Meehan (2005) points out that

\footnotetext{
${ }^{80}$ Mohammad Jasim Uddin., Microcredit, Gender and Neoliberal Development in Bangladesh (Helsinki: Publications of the Department of Social Research: 2013), 7

${ }^{81}$ Ibid., 8.

${ }^{82} \mathrm{Id}$.

${ }^{83}$ Daniel Hardy, Paul Holden, and Vassili Prokopenko, "Microfinance Institutions and Public Policy" Policy Reform 6, no. 3 (September 2003): 158.

${ }^{84}$ Ibid., 153.
} 
with the current trends in the microfinance industry international donors would be unable to provide the funds to accommodate the rapid scaling up of the industry. ${ }^{85}$

Cunningham and Stamer (2005) showed that microfinance's ability to create sustainable growth is also dependent upon its interaction with local economic development schemes. These schemes follow the basic premise that "public businesses and non-governmental sector partners should work together to foster better conditions for economic growth." ${ }^{\prime 86}$ Newby (1999) however showed that these types of programs have often been discredited for their focus on the local level of economic development because they are often constrained by national and international policies that stem from tax regimes, resource allocation, and trade agreements ${ }^{87}$ The problem however is that global economic policies tend to be single minded in that they focus exclusively on "global trade and attracting inward investment" and tend to ignore those local level political and socio-economic factors that can lead to a program's success or failure ${ }^{88}$ As such, microfinance programs tend to fail when they mimic the political economy of other countries, and are not tailored to the nation in which the MFI is to operate. Cunningham and Stamer (2005) show that interaction with the local economy is essential when setting up a development project, but MFIs tend to mimic already established successful programs and therefore set themselves up for failure.

Ahmad (2003) additionally showed the problems with NGO fostered microfinance schemes in Bangladesh. He found that such programs suffered from non-accessibility to the poorest, low return, misuse and an overemphasis on repayment. He showed that microfinance

\footnotetext{
${ }^{85}$ J. Meehan, “Tapping Financial Markets for Microfinance" Grameen Foundation USA Publication Series (2005).

${ }^{86}$ Shawn Cunningham, and Jorg Meyer-Stamer, "Planning or Doing Local Economic Development? Problems with the Orthodox Approach to LED" Africa Insight 35, no. 4 (December 2005), 5.

${ }^{87}$ Les Newby, "Sustainable Local Economic Development: A New Agenda for Action?" Local Environment 4, no. 1 (1999), 68.

${ }^{88}$ Newby (1999), 67.
} 
should be given with services like education and healthcare awareness. Ahmad and many other scholars have found that the overemphasis of microcredit in microfinance has been to its own detriment. ${ }^{89}$ Ahmad therefore looks at why NGO fostered programs may fail. While he does show that these programs are prone to failure, he does not really cover why. This project theorizes that the resulting NGO fostered failure is actually a function of mimicry among the NGO's who set up microfinance programs.

Creation of Debt Cycles. According to the literature, over indebtedness has become an issue for microfinance (Woolcock, 1999; Yaron, 1994; Ahmed, 2003; Rhyne, 2001; Armendariz, Beatriz, and Morduch, 2010; Bateman, 2010). Over indebtedness is simply the creation of more debt in order to pay off existing debt, a debt cycle. This is fostered by MFIs repayment rules that encourage repayment of loans but do not discourage that repayment from another loan. Over indebtedness is created by the proliferation of microfinance institutions. The proliferation of MFIs has resulted in a multitude of institutions for clients to join..$^{90}$ Clients took advantage of the credit from so many institutions and began maintain two or more loans as outstanding at a time. ${ }^{91}$ Clients began to take on more than they could handle and in turn began using one loan to pay off another creating debt cycles that began a quick route to financial disaster for many. Over indebtedness occurs when clients take out an additional loan to pay back the initial loan, and then repeat this process creating a cycle of debt from which the client cannot escape.

One of the major studies in the microfinance literature that looks at the impact of over indebtedness is the Banana Skins survey ${ }^{92}$ The 2008 survey "Microfinance Banana Skins Risks

\footnotetext{
${ }^{89}$ Mokbul Morshed Ahmad, "Distant Voices: The Views of the Field Workers of NGO in Bangladesh on Microcredit" The Geographical Journal 169, no. 1 (March 2003): 65-74.

${ }^{90}$ Elisabeth Rhyne, "Commercialization and Crisis in Bolivian Microfinance" Microenterprise Best Practices (PCE-C-00-96-900040-00: November 2001), 11.

${ }^{91} \mathrm{Id}$.

${ }^{92}$ The Banana Skins Survey was first done in 2008 and aimed to identify the risks affecting the growth and viability of commercial microfinance institutions. They surveyed 305 industry participants from 74 countries with
} 
in a Booming Industry" argues that microfinance's move toward commercialization has resulted in mission drift where the desire for profits has resulted in a shift toward higher interest rates over the desire to help the poor. ${ }^{93}$ Additionally, the study argues that the biggest problems with microfinance are competition among MFIs for clients, and the role of government regulation. ${ }^{94}$ Hilton (2012) showed in the "Banana Skins" survey that the problem of over indebtedness in microfinance was still an issue (Hilton, 2012, 2008). ${ }^{95}$ Other literature on over indebtedness in microfinance has also shown that key themes are over lending, taking out loans to repay loans and overconfidence in the joint guarantee. (Bateman, 2011; Copestake, et al. 2005; Copestake, 2007; Cull, Kunt, and Morduch, 2008, 2007; Dorfleitner, Leidl, and Priberny, 2013; Rhyne, 2003, 2001; Taylor, 2011, 2012).

Sriram (2010) argued that after a phase of intense competition in Bolivia led to "reckless lending [and] over indebtedness of the client that eventually caused cracks" in the system. ${ }^{96}$ Additionally, she highlighted that the "overzealous suppliers of credit meant that the client...had begun to resort to adverse usage of credit." ${ }^{, 97}$ Weber (2004) showed that loans were typically used for consumption and that repayment is often over-lapping resulting in vicious cycles of debt and over-indebtedness. ${ }^{98}$

29\% being from North America, 24\% from Europe, and 19\% from Latin America. They found that competition, political interference, and mission drift were in the top seven for fasts rising among risks for the MFI industry. The largest the main risk was too much funding rather than too little highlighting the fact that with a rise in mission drift microfinance could "fall out of fashion."

${ }^{93}$ Bananaskins 2008., 1.

${ }^{94} \mathrm{Id}$.

${ }^{95}$ The sponsor of the Banana Skins surveys argued that the new shift toward commercialized microfinance was a factor in client over indebtedness but that clients needed access to a full range of financial services and that the trend toward debt was actually one of success not failure.

${ }^{96}$ Sriram., "Microfinance: A Fairy Tale Turns into a Nightmare" 2010., 12.

${ }^{97} \mathrm{Id}$.

${ }^{98}$ Heloise Weber, “The 'new economy' and social risk: banking on the poor?" Review of International Political Economy 11, no. 2 (May 2004), 365. 
Rhyne (2001) looks at the microfinance crisis in Bolivia highlighting one way that MFIs become ineffective. She showed that many clients in Bolivia actually belong to more than one MFIs, many clients had loans at Pro Mujer and at Banco Sol, and this created massive overindebtedness among clients. ${ }^{99}$ The over-indebtedness of the clients resulted in delinquency problems as well as loan cycling problems. Rhyne argues that when the financial crisis hit Brazil resulting in currency devaluation, the already over-indebted clients were hit harder because demand for their wares decreased and they were unable to export their products because of Bolivia's crackdown on informal importing and exporting. ${ }^{100}$ The surrounding financial climate of Bolivia created a problem for microfinance because they shifted from trying to help clients to spending all their time extracting collections from customers. In response, the clients formed a borrowers union to fight back what had become predatory microfinance institutions. Protests were staged at Acceso, CrediAgil, and Caja los Andes, and Banco Sol, and they demanded full debt forgiveness. The extra attention highlighted how these banks were illegally collecting debts through harassments, using collected debts to make new loans, and mishandling membership dues. As a result, Asofin and Superintendency of Banks collapsed, only to resurface later with different leaders. ${ }^{101}$ Rhyne's study is important because it showed not only how a financial crisis sparked the downfall of MFIs but shows some insight into how MFIs could be mismanaged. This section explained how over-indebtedness is problematic for microfinance's ability to generate poverty alleviation.

Commitment to Self-Sufficiency. The effect of subsidies has long been debated in the microcredit and microfinance literature. The core focus of many microfinance scholars is to

${ }^{99}$ Elisabeth Rhyne., "Commercialization and Crisis in Bolivian Microfinance" Microenterprise Best Practices (2001): 11-12.

${ }^{100}$ Ibid., 12.

${ }^{101}$ Ibid., 12-13. 
address the issue of how to make microfinance sustainable. Morduch (2000) shows this conundrum by highlighting the fact that the Grameen Bank model, upon which most modern microfinance likes to take its cues, is not sustainable. He showed that interest rates on their loans would need to be doubled in order for the bank to break even. ${ }^{102}$ Rosenberg (1998) additionally showed that only one percent of programs are financially sustainable and perhaps only five percent would ever become so. The remaining $95 \%$ will fold or continue with the use of subsides. Nancy Barry (1995) also argues that subsides programs are bound to fail. Buckley (1997) highlights that sustainability in microcredit organizations is rare by looking at Kenya, Malawi, and Ghana. By highlighting the issues in Kenya specifically, Buckley showed that those who did receive credit from microcredit organizations did not move toward self-sufficiency or graduate away from the credit program despite being in a fourth loan cycle. He showed that profitability of these organizations was negligible. Buckley in essence showed how high repayment rates could exist while the microcredit organizations continue to need to be subsidized to exist. ${ }^{103}$

Furthermore, Morduch (1999) showed that subsidies originated from many funding sources, primarily from donor agencies (NGO’s), regional banks that are rationed at a lower interest rate, government bonds (also rationed at low interest of 4-5\%), the International Fund for Agricultural Development, and governments like Norway, Sweden and the Netherlands who provide subsidies. ${ }^{104}$ Nieto (2005) showed that private institutional investors that channel funds from donors, private lenders, investors, as well as, the World Bank and other multilateral

\footnotetext{
102 Jonathan Morduch, “The Microfinance Schism” World Development 28, no. 4 (2000): 617-629.

${ }^{103}$ Graeme Buckley, "Microfinance in Africa: Is it Either the Problem or the Solution?" World Development 25, no. 7 (1997): 1088 .

104 Jonathan Morduch, "The Role of Subsidies in Microfinance: Evidence from the Grameen Bank" Journal of Development Economics 60 (April 1999): 240.
} 
agencies often finance microcredit programs. ${ }^{105}$ Microfinance has no way to differentiate between successful and unsuccessful businesses, which in turn can create debt cycles, as those within the programs use future loans to repay current loans and therefore are making no profit or economic growth. In order for microfinance to be successful it would need to set up permanent "institutions and systems that provide financial services during the loan period as well as the long term" that would make the programs sustainable. ${ }^{106}$

The Importance of the Economically Active Poor. The literature shows that the clients of microfinance are typically not the very poor, but instead tend to be the economically active poor. Who actually gets the loans is a major point of study in the literature on microfinance. The literature shows that many MFIs choose clientele based on their ability to pay back even a fraction of the loan, and that while they claim to lend to the poorest of the poor they actually lend to a groups that are economically active poor. Microfinance claims to help the poorest of the poor and many NGOs and donors support these programs under that guise. The literature shows that microfinance claims to help the poorest of the poor, because it looks good to say so and that the distinction between extremely poor and economically active poor is an important distinction for microfinance's ability to reduce poverty.

Woller (2002) highlights this move by looking at the possibility to provide financial services to the poor. His main contribution here is to argue that operational policies of microfinance institutions focus too heavily on the credit portion and therefore create vulnerability and prevent the very poor population from participating (Woller 2007, 2002). Hartarska and Mersland (2012) looked at the mechanisms for effectively reaching poor clients

\footnotetext{
${ }^{105}$ Begona Gutierre Nieto, "Private Funding of Microcredit Schemes: Much Ado about Nothing" Development in Practice 15, no. 3\&4 (June 2005): 490.

${ }^{106}$ Mokbul Morshed Ahmad, "Distant Voices: The Views of the Field Workers of NGO in Bangladesh on Microcredit” The Geographical Journal 169, no. 1 (March 2003): 18.
} 
and found that competition does not improve efficiency and that MFIs can only serve poor customers if they remain financially sustainable. ${ }^{107}$ They show that while the literature on microfinance is concerned with poverty outreach its main concern is with financial sustainability and that MFIs often do not target the poorest of the poor. Bison, Dalton, and Wilson (2012) also argued that the microfinance literature is shifting its definition of "success" away from the helping the poor out of poverty and instead focusing on financial self-sufficiency. ${ }^{108}$ Furthermore, they argue that MFIs shift to giving larger loans to a more secure client base is creating a shift away from poverty reduction and a shift away from helping the poorest of the poor. ${ }^{109}$ Simanowitz (2002), among other scholars, have additionally argued that this shift has deliberately excluded the poorest sectors from microfinance programs (Ahlin, 2003; Azzam, et al., 2012; Elahi and Rahman, 2006; Hermes and Lensink, 2011; Jain, 2009).

Robinson (2001) argues, "savings facilities are often more in demand among the poor than credit services." ${ }^{110}$ She argues that it is important to make a distinction between the extremely poor and the economically active poor. Furthermore, she argues that the "poverty line is not directly relevant for microfinance." 111 As such, she highlights one of the key issues with microfinance in that "when loans are provided to the very poor, the borrowers may not be able to use the loans effectively." 112 Microfinance loans, despite claims otherwise, do not reach the poorest of the poor because "the demand from poor people is not for the products and services

${ }^{107}$ Hararska and Mersland., 2012. "Which Governance Mechanisms Promote Efficiency in Reaching Poor Clients?" European Financial Management 18, no 2, 219.

${ }^{108}$ Arjun Bisen, Bronwen Dalton, and Rachel Wilson., 2012, "The Social Construction of the Microfinance Industry: A Comparison of Donor and Recipient Perspectives" Cosmopolitan Civil Societies Journal 4, no. 2, 62.

${ }^{109}$ Ibid., 67.

${ }^{110}$ Robinson., 2001., 72.

${ }^{111} \mathrm{Id}$.

${ }^{112}$ Robinson, 2001, 73. 
that the microfinance industry has emphasized." ${ }^{113}$ Measuring outreach is difficult as Khandker (2005) and Dunford (2006) both argue that the problem occurs between measuring the core poor and the moderately poor. ${ }^{114}$ Hulme and Mosely (1996) and Copesake et al. (2005) mirror similar arguments showing that it is often the better off poor who gain the most from microfinance. ${ }^{115}$ This section discussed how poverty outreach is a prevalent issue with the mimicked program of microfinance.

\section{Socio-Cultural Critiques of Microfinancing}

The literature on microfinance and socio-cultural issues has grown substantially. As such, this section addresses the socio-cultural issues that impact microfinance's effectiveness. It focuses on the societies where microfinance programs are designed to operate and how issues of social norms and traditional culture can impact the ability of programs to operate under the local and regional conditions. The socio-cultural factors that impact effectiveness of microfinance that are covered include issues of gender targeting and social capital creation. The last part of the literature review section addresses these socio-cultural factors.

Gender Targeting. In addition to the previously discussed economic factors that impact MFIs effectiveness, there are also socio-cultural factors, including issues of gender targeting, local political practices, and social capital. Gender and microfinance has been a major focus in research. A key issue in the literature is whether MFI loans ultimately improve the lives or economic condition of women who receive the loans. The revolution that has become microfinance over the last twenty years has not only focused on the importance of development

${ }^{113}$ Joanna Ledgerwood, ed., The New Microfinance Handbook: A Financial Market System Perspective (International Bank for Reconstruction/World Bank Publishing: 2013), 67.

${ }^{114}$ Niels Hermes and Robert Lensink, "Impact of Microfinance: A Critical Survey" Economic and Political Weekly 42, no. 6 (February 2007), 464.

${ }^{115} \mathrm{Id}$. 
for the poor, but also on many programs that have specifically targeted women in hopes of empowering them, and thereby creating equality. The microfinance industry has spawned an important political connection between women's empowerment and loans which has created a social cause for donors and Microfinance Institutions (MFIs) to get behind and continue to fund microfinance programs (Dobra, 2011; Johnson, 2005, 2000; Jupp, Ali and Barahona, 2010; Kabeer, 2001; Rankin, 2001; Weber, 2004; Yusuff, 2010; Uddin, 2013).

Mel, McKenzi, and Woodruff (2009) investigate the differences in profitability and growth of enterprises run by females. They suggest that most female-owned enterprises grow slower and generate lower profit levels than male owned enterprises. ${ }^{116}$ The question then follows why microfinance continues to focus on loans to women. Rahman (2001), Karim (2008), and Moodie (2013) argue that the issue with gender and microfinance stems from the Grameen Bank model, where Yunus noticed that women were more reliable to repay their loans. ${ }^{117}$ Additionally, they argue that this high repayment rate actually stems from a "patriarchal economy of shame" where by microfinance assumes that self-employed women would use the loans, but in fact it is men that do so justified by "deeply entrenched systems of gender inequality and kinship obligations." ${ }^{118}$ Furthermore, Moodie argues that the activities undertaken through microfinance loans are domestic in nature and that these informal sector jobs are always "constrained by domestic responsibilities." 119

${ }^{116}$ Suresh de Mel, David McKenzie, and Christopher Woodruff., “Are Women More Credit Constrained? Experimental Evidence on Gender and Microenterprise Returns" American Economic Journal: Applied Economics 1, no. 3 (July 2009), 2-3.

117 Aminur Rahman., Women and Microcredit in Rural Bangladesh: An Anthropological Study of Grameen Bank Lending. (Westview Press, 2001); Megan Moodie., "Microfinance and the Gender Risk: The Case of Kiva.org" Signs 38, no. 2 (Winter 2013); 289

${ }^{118}$ Megan Moodie., "Microfinance and the Gender Risk: The Case of Kiva.org" Signs 38, no. 2 (Winter 2013), ${ }^{119} \mathrm{Id}$. 
When it comes to microfinance and gender in Latin America, the theme of the feminization of poverty has arisen (Baden, 1999; Cagatay, 1998; Chant, 1997, 2003, 2008; Davids and van Driel, 2005; Medeiros and Costa, 2006; Moghadam, 2005; and Wennerholm, 2002). ${ }^{120}$ Atal, Nopo, and Winder (2009) further this argument by looking at gender and wage gaps in Latin America. They found that part of the wage gap stemmed from the difference in types of jobs men and women get. Furthermore, they show that women's presence in the region's informal sector is a contributing factor to the gender wage gaps. Haase (2007) furthermore argues that women throughout Latin America lacked management skills and the ability to transform human capital-education, experience, and skills - into revenue. ${ }^{121}$ Haas argues that part of the problem is that the trend of gender segregation has resulted in women who are unrepresented in the skilled labor market. The restrictions on where they work and what kind of work they do are also important problems for female entrepreneurs in the region that microfinance programs do not address. ${ }^{122}$

Additional literature on gender and Latin America culture highlights issues of Latin culture and empowering women through microfinance. Silverberg (2014) argues that problems with the way that microfinance employs group lending tends to cause problems in households, which challenge societal norms. ${ }^{123}$ Silverberg and Hossain (2002) additionally argue that while microfinance is promoting a benefit to empower women, and that MFIs target women with this belief. Furthermore, they argue that women in particular in machismo societies, like Latin America, are more intimidated by male organizations workers and therefore less likely to

\footnotetext{
${ }^{120}$ Sylvia Chant., "The 'feminisation of poverty' and the 'feminisation' of anti-poverty programmes: Room for revision?." The Journal of Development Studies 44, no. 2 (2008): 165-197; T. Davids and F. Van Driel., The Gender Question in Globalization: Changing Perspectives and Practice. (Ashgate, Aldershot Publishing, 2005).

${ }^{121}$ Dwight Haas., "Closing the Gender Gap" ESR (Fall 2007), 6.

122 Ibid., 7.

${ }^{123}$ Sarah Silverberg., "One Size Does Not Fit All: A Study of Microfinance Practices in Peru” Undercurrent Journal 10, no 2 (Fall/Winter 2014), 49.
} 
challenge the organization. ${ }^{124}$ The literature also highlights the domestic violence issues surrounding microfinance as women are "reprimanded for being distracted from household activities" (Hossain, 2002; Schuler, 1998; Pait, 2009; Silverberg 2014). ${ }^{125}$ Silverberg additionally argues that women's empowerment and independence could lead to more violence, as men in the machismo Latin American society see microfinance as instigating problems as women become more independent. Perhaps more importantly Silverberg argues that microfinances practices need to be revised as women move into more active roles in the economy and contribute more as heads of households. ${ }^{126}$

Johnson (2005) addressed the issues of gender targeting in microfinance programs by looking at MFIs in Malawi. She found that MFI programs have done little to understand gender relations in which their women clients are embedded and therefore their programs are not tailored to have the greatest impact. ${ }^{127}$ Van Staveren (2001) also had found that by not including indicators of market access microfinance loans would promote women's labor but not market accessibility. Additionally, she found that targeting of women often creates gender distortions, as women are not given access to information about financial services. Wright (2000) discovered that in Bangladesh for the Grameen Bank 63\% of women had no control over the loan use and that women are forced to take on loan repayment when the men misuse the loans. ${ }^{128}$

Claims for the benefits of gender targeting in microfinance have become an industry standard. However, Johnson (2005) argued that MFIs had done little to understand the gender

${ }^{124} \mathrm{Id}$.

${ }^{125}$ Silverbert., (2014), 49.

${ }^{126}$ Ibid.

${ }^{127}$ Susan Johnson, "Gender Relations, Empowerment and Microcredit: Moving on from a Lost Decade" The European Journal of Development Research 17, no. 2 (June 2005), 225.

${ }^{128}$ Graham A.N. Wright, Microfinance Systems: Designing Quality Financial Services for the Poor (Zed Books: London, 2000), 23. The ideal of an increased bargaining position of women stems from a 1960s hypothesis of Blood and Wolfe, family sociologists that found that "the power balance within marriage is determined by comparative valued resources of spouses" (Wright, 24). 
relations of their clients so their programs. ${ }^{129}$ Allen (2006) stated, "male exclusion can lead to negative consequences for women" because their participation is seen as threatening and such resistance can lead to their loans being "hijacked." ${ }^{130}$ Armendariz and Roome (2008) showed that "excluding husbands can be counterproductive because of informational asymmetries."131 Suresh, McKenzie, and Woodruff (2009) found that women do not obtain a permanent increase in income following the loan. ${ }^{132}$ Menon-Sen (2012) further argued the point that gender mainstreaming and the thought of microfinance as a "magic bullet that can cure both poverty and women's subordinations, has further constrained the space for promoting women's rights."133

Gender and Best Practices. When discussing gender empowerment and microfinance in Latin America, it is also important to look at the impact of domestic violence has in Latin America. Violence against women frequently has the impact of restricting civil, political, social, cultural, and economic rights. Ingoldsby (1991) argues that the cultural context in Latin America of a machismo male makes aggressiveness and hyper-sexuality acceptable. ${ }^{134}$ Furthermore, Wells (1968) argues that traditionally Latin American culture has focused on male dominance and machismo as typified in the political and military strongman caudillos. ${ }^{135}$ After the wars of Independence in Latin America, the caudillo would take up rule by force establishing a caudillaje political system that was characterized by armed patron-client sets and the use of violence.

${ }^{129}$ Susan Johnson, "Gender Relations, Empowerment and Microcredit: Moving on from a Lost Decade" The European Journal of Development Research 17, no. 2 (June 2005), 225.

${ }^{130}$ Armendariz and Roome, "Gender Empowerment in Microfinance” MPRA Paper No. 31040 (May 2008 ), 9.

${ }^{131}$ Armendariz and Roome., 2008, 20.

132 Suresh de Mel, David McKenzie and Christopher Woodroof, "Are Women More Credit Constrained? Experimental Evidence on Gender and Microenterprise Returns" American Economic Journal: Applied Economics 1, no. 3 (July 2009), 31.

${ }^{133}$ Kalyani Monon-Sen, "Fraying at the Edges? Discordant Notes from the Margins of India Shining" in Johnson and Wadi, eds, Review of Women's Studies 7 (Institute of Women's Studies Birzeit University: 2012 ), 81.

${ }^{134}$ B.B. Ingoldsby, "The Latin American Family: Familism vs. Machismo" Journal of Comparative Family Studies 22, no. 1 (1991), 57-62.

135 H. Wells., The Modernization of Puerto Rico: A political study of changing values and institutions. Harvard University Press (Cambridge, 1968), 68. 
Kinzer (1973) follows that tradition that caudillos and machismo were part of the $19^{\text {th }}$ century power structure and that current references to machismo are stereotypes. ${ }^{136}$ However, Chant and Craske (2003), Pena (2006), Mayo and Resnick (1996), and Wilson (2014) contend that the traditional value system that has emerged out of caudillo rule has resulted in continued forms of gendered oppression alongside political oppression, highlighting the populist and dictatorial regimes of Peron of Argentina, Castro in Cuba, and Chavez in Venezuela. ${ }^{137}$ Certainly political violence is Latin America is just as prevalent as it was in the $19^{\text {th }}$ and $20^{\text {th }}$ century. From that, the acceptable use of force as a social construct has emerged. This has resulted in a sociopolitical legacy of caudillos and machismo has creates asymmetric power configurations within households. Adopting a similar definition as the UN, that gender based violence is any form of discrimination leading to inequality, and using power in a sociopolitical context as embodied in machismo, violence against women is still an issue in Latin America and machismo very much is a modern concept contrary to Kinzer's argument. Macias-Gonzalez and Rubenstein (2012) follow support this argument as well, stating that gender is influenced by the norms and behavioral codes of society. ${ }^{138}$ If the code is accepting of violence against women, violence will ensue.

The intersection of violence and economics is an important factor to consider. Ellsberg, Penna, Herrera, Liljestrand and Winkvist (1999) argue that asymmetry between partners creates

${ }^{136}$ N.S. Kinzer., "Priests, Machos and Babies: of, Latin American Women and the Manichaean Heresy" Journal of Marriage and Family 35 (1973), 300-311.

${ }^{137}$ Sylvia Chant and Nikki Craske., Gender in Latin America. London (Latin America Bureau Press, 2003); Yolanda Quinones Mayo and Rosa Perla Resnick., "The Impact of Machismo on Hispanic Women" Affilia 11, no 3 (Fall 1996), 257-277; G Pena "A new Mexican Nationalism? Indigenous Rights, Constitutional Reform and the Conflicting Meanings of Multiculturalism" Nations and Nationalism 12, no 2 (2006), 279; Tamar Diana Wilson "Violence Against Women in Latin America" Latin American Perspectives 41, no 1 (Jan. 2014), 3-18.

${ }^{138}$ Victor Macias-Gonzales and Anne Rubenstein., Masculinity and Sexuality in Modern Mexico. Albuquerque (University of New Mexico Press, 2012) 
interpersonal violence. ${ }^{139}$ Heise (1998) additionally finds that asymmetry can be created by socioeconomic violence. A structural change in the family dynamic relationship creates asymmetry and increases the risk of gendered violence. ${ }^{140}$ When microfinance loans are given to women without regard to the historical and social contexts that exist, they inherently create power asymmetries and gendered violence.

Duvendack and Palmer-Jones (2011) argue that impact assessments that measure empowerment actually measure MFI participation by gender on indicators such as "labor supply, school enrollment, expenditure per capita, and non-land asset ownership." ${ }^{\text {"41 }}$ They highlight the fact that impact assessments are "very sensitive to unobservables." ${ }^{142}$ Kaboski and Townsend (2005) additionally add to our understanding of how MFIs typically are measuring impact by looking at village-level MFIs. They measure impacts by looking at membership level, savings mobilization, and lending ability to make the claim that MFIs have an impact on households. They show that institutions that follow policies that promote these things have a 5\% higher annual growth in assets to villagers. ${ }^{143}$ Mayoux (2008) defines empowerment as a "process through which those who are currently disadvantaged achieve equal rights, resources, and power." ${ }^{144}$ The issue with empowerment is that everyone has a different definition of what it is; therefore, MFIs typically do not measure any component of empowerment.

Social Capital. When it comes to microfinances' impact, the major concern with the literature is its ability to create social capital. Kim (2007) argues that microfinance can create

${ }^{139}$ MC Ellsberg, R Pena, A Herrera, J Liljestrand, and A Winkvist., "Wife abuse among women of childbearing age in Nicaragua" American Journal of Public Health 89, no. 2 (February 1999), 241-244.

${ }^{140}$ Lori Heise., "Violence Against Women" Violence against Women 4, no 3 (June 1998), 262-290.

${ }^{141}$ Maren Duendack and Richard Palmer-Jones "High Noon for Microfinance Impact Evaluations"ReInvestigating the Evidence from Bangladesh" DEV Working Paper 27 (2011), 9.

${ }^{142} \mathrm{Id}$.

${ }^{143}$ Joseph Kaboski and Robert Townsend., "Policies and Impact: An Analysis of Village-Level Microfinance Institutions" Journal of the European Economic Association 3, no. 1 (March 2005), 3.

${ }^{144}$ Ibid., 29. 
social capital through knowledge, skills, and financial resources, which allow participants to affect positively the outcomes of their own lives. Through social power, social capital is created as defined as a network of relationships that builds links between communities and groups of actors. It is in this social capital idea that micro-loan and microfinance programs promise the greatest movement for empowerment. ${ }^{145}$ However, the research on the impact of social capital and microfinance is mixed. Armendariz and Morduch (2005) actually highlight the fact that the social cohesion that microfinance claims to create through their group lending structures is actually detrimental to repayment rates. ${ }^{146}$ Wydick (1999) concluded similarly that in Guatemala, social ties had little impact on repayment rates and in fact, that friends did not make reliable group members. ${ }^{147}$ Ahlin and Townsend (2003) again found that proxies for social ties were associated with weak repayment performance in Thailand. ${ }^{148}$ However, Karlan (2003) and Wenner (1995) found that in Peru and Costa Rica social capital was a positive force. ${ }^{149}$ Adams and Mayoux (2001) argue that the idea of social capital imbedded in microloans is "grossly overstated" and that while microfinance may in fact give access to credit it does not mean the same thing as open access. ${ }^{150}$

One of the main problems with the contradictory research on microfinance and social capital focuses on the multitude of definitions used for social capital. Healey, et al. (1999)

145 Julia C Kim, "Understanding the Impact of a Microfinance-Based Intervention on Women's Empowerment and the Reduction of Intimate Partner Violence in South Africa" American Journal of Public Health 97, no. 10 (October 2007), 1796.

${ }^{146}$ Beatriz Armendariz de Aghion and Jonathan Morduch, The Economics of Microfinance (Cambridge MIT Press, 2005): 103.

${ }^{147}$ Bruce Wydick, "Can social cohesion be harnessed to repair market failures? Evidence from group lending in Guatemala." The Economic Journal 109 (1999), 463.

${ }^{148}$ Christian Ahlin, and Robert Townsend, "Using repayment data to test across models of joint liability lending." Working project, Department of Economics, University of Chicago (2003), 5-7.

${ }^{149}$ Mark Wenner, "Group credit. A means to improve information transfer and loan repayment performance." Journal of Development Studies 32 (1995): 263-281.

${ }^{150}$ Adams, Dale, and Linda Mayoux. 2001. “Crossfire.” Small Enterprise Development 12(1): 4-6. 
explains that social capital is typically thought of as a network of relationships plus norms by which actors have to conform. ${ }^{151}$ Rydin and Holman (2004) show that social capital is often distinguished by two separate definitions, those being, networks within the community or group and links between communities or groups of actors. ${ }^{152}$ Moses Acquaah (2008) looks at social capital creation through social networking relationships in Ghana and found that social capital was responsible for developing social relationships with politicians that can therefore provide access to resources and information for business activities. ${ }^{153}$ However, Acquaah points out that social capital from social ties with government officials can be costly because it can hide the business's ability to pursue new opportunities and therefore hinder its growth. ${ }^{154}$ Woodworth (2008) additionally looks at social capital and microcredit. He shows that studies concerning social capital are varied because they are often centered on different concepts of what constitutes social capital. Woodworth therefore argues that when discussing social capital in the context of microfinance it should be defined the way Yunus has defined it several criteria, including it should help poor families overcome poverty, target poor women, and should be based on trust not collateral, and such credit should be used to create self-employment not consumption. ${ }^{155}$ Kah, Olds, and Kah (2005) further illustrate this point by looking at the creation of social capital among microfinance institutions in Senegal. They define social capital as social relationships "within and between microcredit institutions and financing NGOs, donors, and governments."156

\footnotetext{
${ }^{151}$ Healey, et al. "Institutional capacity-building, urban planning and urban regeneration projects" Futura 18, no. 3 (1999): 117-137.

152 Yvonne Rydin and Nancy Holman, "Re-evaluating the Contribution of Social Capital in Achieving Sustainable Development" Local Environment 9, no. 2 (April 2004): 117-133.

${ }^{153}$ Moses Acquaah, "Social Capital: The Benefits, Potential Costs, and Prospects" ESR Review 10, no. 2 (Fall 2008): 13-14.

154 Ibid., 16.

${ }^{155}$ Warner Woodworth, "Reciprocal Dynamics: Social Capital and Microcredit” ESR Review 10, no. 2 (Fall 2008): 36 .

156 Jainaba Kah, Dana Olds, and Muhammadou Kah, "Microcredit, Social Capital, and Politics: The Case of a Small Rural Town - Gossas, Senegal” Journal of Microfinance 7, no. 1 (Summer 2005): 119.
} 
Essentially, they define social capital on a broader spectrum bringing in the impact of international organizations. ${ }^{157}$ This highlights the obvious problem with social capital in the microfinance literature and why one study is positive while another is negative, without a standardized definition of what social capital, it is difficult to measure and therefore determine its impact on microfinance. What Kah, Olds, and Kah do point out is that there is a move in the microfinance literature to look at the role of international organizations. This literature highlights the importance of measuring social capital and its impact, because if the MFI is able to create social capital it would be successful, however, if it did not create social capital it could fail not only socially but also economically.

\section{Political Critiques of Microfinance}

The literature on microfinance and political issues is still a new approach. The literature shows that microfinance can interact with the political, but it does not get at the core issue of how that interaction can hinder poverty alleviation efforts. These studies have focused exclusively on the financial side of microfinances' interaction with the government, and therefore, have little insight into the deeper political processes that are occurring. This dissertation argues that because of institutional mimicry and the adherence to a best practices model, loans do not result in poverty alleviation but instead it results in overindebtedness, baring the very poor from the financial services that they need, and spurring corruption and soaring interest rates as the domestic political systems frame the interactions between the MFIs and the state. The political factors that impact effectiveness of microfinance that are covered include issues of local political practices that lead to corruption and the influence of international organization on perpetuating the best practices model of microfinance.

\footnotetext{
${ }^{157}$ Id.
} 
Local Political Practices. A growing theme in the literature has been the issue of the role of the domestic government in microfinance. The literature in microfinance has become interested in the impact of the domestic environment in which microfinance institutions operate. Much of the literature concerns itself over what role the government plays. The arguments in the literature center on the implementation of a governmental regulatory model for microfinance to ensure client protection like any other bank would. In focusing on the domestic political system in which microfinance operates, the literature also highlights how government involvement can create corruption and therefore, argues the government should not be involved in microfinance at all. Microfinance's interaction with the domestic environment is often discussed in the literature in terms of its institutional capacity to regulate the banking capacity of the MFIs themselves.

Another issue the literature highlights is how the domestic environment can undermine the microfinance institutions ability to reduce poverty through corruption or weak state structures. De la Torre, Gine, and Vishwanath (2011) look at the role of the government in microfinance institutions in India. They found that the frequent interference by the government could actually undermine the culture of repayment as borrowers take advantage of lax enforcement of credit contracts. ${ }^{158}$ Olu (2009) shows how in Nigeria lax government enforcement over black markets creates unfair competition or micro-businesses. ${ }^{159}$ Therefore, their argument is that the role of the government should not be that of replacing private agents, such as NGO's and private funders, but the government needs to be a regulatory body that supports the funding in the market. Shylendra (2006) showed that in India weak state structures

${ }^{158}$ Jordi de la Torre, Xavier Gine, and Tara Vishwanath., "After the Microfinance Crisis: Assessing the Role of Government-Led Microcredit Alternatives" Policy Research Working Project The World Bank WPS5808 (September 2011).

${ }^{159}$ Ojo Olu., "Impact of Microfinance on Entrepreneurial Development: The Case of Nigeria" The International Conference on Administration and Business (Bucharest, November 2009): 539. 
resulted in subsidies that leaked the benefits to non-poor, high failure rate of self-employment projects, and loan repayment problems. ${ }^{160}$ Much of the literature on the role of the government in microfinance therefore has to do with the government's role as a regulatory body for the MFI to ensure not only protection for the client in case of bank failure but for the growth of the MFI market to ensure repayments. The microfinance and regulation question became a concern when the institutions as NGO's began to function as semi-banks but not under the same rules or regulations of banks. The most important issue is the transparency of interest rates, where the rates are sometimes not disclosed and involve upfront fees or balance basis calculation. ${ }^{161}$

The literature also shows how government interaction with MFIs would create corruption among political elites by making repayment dependent upon votes for candidates. The larger phenomenon shown here was that when the political elites controlled too much of the MFI they would use promises of lax repayment or increase in loans to secure votes. Cole (2009) found that government owned banks did significantly capture more loans during election cycles. ${ }^{162}$

Sapienza (2004) found that Italian banks charged lower interest rates during election cycles, and Khwaja and Mian (2005) found that in Pakistan government owned banks would forgive defaulting loans during the election cycle. ${ }^{163}$ Dinc (2005) examined the lending of government owned banks during the election cycle as well showing an increase of about $11 \%$ relative to

${ }^{160}$ H.S. Shylendra, "Mainstreaming Microfinance for Poverty Alleviation: Need for a Proactive Policy and Regulatory Framework" in YSP Thorat, ed. Towards a Sustainable Microfinance Outreach in India: Experiences and Perspectives (Microcredit Innovations Department Thoughtscape design studio, May 2006): 178.

${ }^{161}$ Savita Shankar and Mukul Asher., "Regulating Microfinance: A Suggested Framework" Economic \& Political Weekly 45, no. 1 (January 2010), 16-17. Other scholars have also looked at the regulatory framework for MFs, including Ahmed, Brown, and Williams, 2013; Barry, 2012; Basher, 2012; Bloom, et al., 2013; Cull, 2009; Haque and Fatema, 2012; Jobim, 2012; Madae, 2011, 2013; Marr and Tubaro, 2011

${ }^{162}$ Shawn Cole., "Fixing Market Failures or Fixing Elections? Agricultural Credit in India" American Economic Journal: Applied Economies 1, no 1 (January 2009), 219.

${ }^{163}$ Ibid., 220. Paola Sapienza., "The Effects of Government Ownership on Bank Lending" Journal of Financial Economics 72, no. 2 (2004): 357-384. Asim Ijaz Khwaja and Atif Milan., "Do Lenders Favor Politically Connected Firms? Rent Provision in an Emerging Financial Market" Quarterly Journal of Economics 120, no. 4 (2005): 13711411. 
private banks. ${ }^{164}$ These studies show that loans were politically motivated and given to certain members aligned with the majority coalition. Torre, Gine, and Vishwanath (2011) showed that the "culture of subsides and frequent government relief undermined the culture of repayment" as borrowers would take advantage of the lax enforcement during election cycles. ${ }^{165}$

There has yet to be a consensus on which is the best regulatory system for microfinance. Schmidt (2000) argues that a "one size fits all approach" will have "adverse effects" because capital adequacy ratios tend to be country specific as does loan provisioning. ${ }^{166}$ Instead he argues for microfinance legislation and regulations that are absent in developing countries. Bates (2007) argues that the government should support the microfinance industry in Latin America. In January 2007, the state-owned Banco Industrial made plans to purchase Prodem, a prominent microfinance institution in Bolivia. In April, of the same year, President Hugo Chavez proposed a US\$1billion bond to fund businesses in Ecuador, Nicaragua, and Haiti. Then in May, the Bolivian government headed by Evo Morales established Banco del Desarrollo Productivo for low-interest microloans. President Alvaro Uribe of Colombia has similarly followed suit launching his own program to promote microcredit. ${ }^{167}$

The growing interest in microfinance in Latin America is seen less as an altruistic reason and more as a way to provide financial services to the poor as quickly as possible. Microfinance is no longer being considered as a blanket policy plan to solve poverty but as more comprehensive financial development plan. Despite this, Ernesto Aguirre, World Bank

\footnotetext{
${ }^{164}$ Serdar Dinc., "Politicians and Banks: Political Influences on Government-Owned Banks in Emerging Markets" Journal of Financial Economics 77 (2005), 453.

165 Jordi de la Torre, Xavier Gine, and Tara Vishwanath., “After the Microfinance Crisis: Assessing the Role of Government-Led Microcredit Alternatives" Policy Research Working Project The World Bank WPS5808 (September 2011), 6-7.

${ }^{166}$ Kirkpatrick and Maimbo., (2002), 299.

${ }^{167}$ Peter Bate., "Governments in Microfinance: Threat or Opportunity?” Microenterprise Americas Magazine,
} (Fall 2007), 1. 
consultant and former banking superintendent from Colombia, suggests that the government's involvement in microfinance as misguided pointing to the agricultural plans of the 1970s and 1980s that used subsides that turned out to be "unsustainable and generated a culture of nonpayment among borrowers." ${ }^{168}$ Bates argues that while Bolivia has had a successful MFI industry, the high interest rates were politically unsustainable because of a lack of regulation. ${ }^{169}$ Bates hints at the idea that MFIs that are tailored after the Compartamos model are unlikely to succeed because they are set up in countries that lack the ability to regulate or control the MFI. This means the MFI is less likely to create poverty alleviation while following the best practices because it does not take into account the local regulatory and governmental environment in which the MFI is operating.

The role of the government in microfinance has been greatly debated in the literature. This starts with the influence that government banks have in channeling funds. Rajan and Zingales (2003) showed that the political elite control the financial resources. Caprio and Peria (2000) showed that government ownership of banks was associated with a greater likelihood of banking crises. La Porta et al. (2002) documented that government owned banks allow politicians to use the banks to further their own political goals. This literature has shown that government owned banks is associates with lower economic growth. ${ }^{170}$ Hubka and Zaidi (2005) argue that the government should exit the microfinance sector because they create unfair competition and create corruption among local elites. ${ }^{171}$

\footnotetext{
${ }^{168} \mathrm{Id}$.

${ }^{169} \mathrm{Id}$.

${ }^{170}$ Serdar Dinc, "Politicians and Banks: Political Influences on Government-Owned Banks in Emerging Markets" Journal of Financial Economics 77 (2005): 454

${ }^{171}$ Ashley Hubka and Rida Zaidi, "Impact of Government Regulation on Microfinance" World Development Report 2005 Improving the Investment Climate for Growth and Poverty Reduction (2005): 1.
} 
Some microfinance literature attempts to propose new regulatory models to deal with this mimicry of best practices. This mainly includes licensing legislation for microfinance institutions. However, as Kirkpatrick and Maimbo (2002) note where licensing legislation is present it is rarely detailed, unlike banking laws where regulation is clear with regard to minimum capital requirements, and financial conditions. ${ }^{172}$ Christian and Rosenberg (2000) suggest that the reason that licensing legislation is so ambiguous may be because governments may look toward this licensing and regulation as a means of "clamping down on troublesome foreign-funded NGO's or other groups that they would like to control more tightly." ${ }^{" 173}$ Greuning, Gallardo, and Randhawa (1998), however, suggest that licensing is uneven because of the inconsistent application regulatory principles. They point to Bolivia, Indonesia, Philippines, Bangladesh, and Sri Lanka as countries that have licensed specialized and regular commercial banks that provide financial services to MFIs. ${ }^{174}$ Swain and Liljiorst (2005) showed that some governments have repressive financial systems and inappropriate regulation that do not allow microfinance institutions to cover costs and risks and earn a profit. Their study hints at the idea that the MFIs do not adequately take into account the local political structures when setting up their programs. Therefore, these programs tend to be mimicked programs of other successful programs and as such, they follow best practices that hinder their poverty alleviation capabilities. ${ }^{175}$

The Role of International Influences. Cull, Demiguc-Kunt, and Morduch (2008) highlights the importance of funding microfinance institutions in a different way by looking at

\footnotetext{
${ }^{172}$ Kirkpatrick and Maimbo., (2002), 296.

${ }^{173}$ Ibid., 297.

${ }^{174}$ Hennie van Gruening, Joselito Gallardo and Bikki Randhawa., “ A Framework for Regulating Microfinance Institutions" Financial Sector Development Department, The World Bank (Dec 1998), 1.

${ }^{175}$ Ranjula Bali Swain and Emilia Lilijefrost, eds. The Democratization of Finance-Future Directions for Microfinance (Uppsala Publishing, 2005): 8.
} 
Banco Compartamos in Mexico. The showed that Compartamos' public offering allowed it to free itself form donor-supported initiatives and grow from 60,000 to 800,000 customers between 2000 and 2007. They argue that micro-lenders should and can compete with mainstream commercial banks. ${ }^{176}$ This version of microfinance is different from the NGO driven MFIs in that they charge increased interest rates, for which Compartamos may see backlash.

Compartamos focused on serving hundreds of thousands poor customers whom they believe would have been worse off financially. Compartamos greatly differs from the NGO's versions of microfinance in that NGO's tend to be run like "social businesses driven by social missions," whereas Compartamos is focused on reducing poverty by self-help rather than income redistribution. ${ }^{177}$ Compartamos is important because it highlights for the first time a significant shift in the microfinance paradigm. It has shown that microfinance institutions are directly linked to the private capital markets. ${ }^{178}$ Since the global financial crisis of 2008 , capital markets as a source of corporate governance have risen, and microfinance is part of this new interaction. ${ }^{179}$ What the changing global economic system and the growth of Compartamos have shown is that commercialized providers of microfinance are the fastest growing dimension of the sector. ${ }^{180}$ This explosive growth shows that microfinance's ability to create profit for its investors has resulted in mimicked programs throughout the developing world.

The field of microfinance is a complex one; there are many types of microfinance and many different ways to do microfinance. In the past thirty years, it has grown in tremendous popularity as the connection between financial development and economic growth has become

\footnotetext{
${ }^{176}$ Robert Cull, Asli Demirguc-Kent, and Jonathan Morduch., "Microfinance Meets the Market” Policy Research Working Project 4630 The World Bank (May 2008): 1-2

177 Ibid., 1-3

${ }^{178}$ Rob Aitken., “Ambiguous Incorporations: Microfinance and Global Governmentality” Global Networks 10, no. 2 (2010), 224.

179 Ibid., 230.

${ }^{180}$ Ibid., 231.
} 
inexorably linked. The shift in development theories has resulted in a new understanding in the way financial markets develop and stimulate the growth of the economy. As a result, the finance in poverty reduction has moved to the forefront of development practices and the prominent vehicle is microfinance. As microfinance has become the go to practice for economic development in underdeveloped countries, microfinance itself has changed. Microfinance today tends to focus more on the international level rather than the local level, resulting in new problems because they are often constrained by policies that stem from tax regimes, resource allocation, and trade agreements. ${ }^{181}$ The problem is that global economic policies tend to be single-minded in that they focus exclusively on "global trade and attracting inward investment" and tend to ignore those local level political and socio-economic factors that create poverty. ${ }^{182}$

\section{Summary and Conclusion}

The emergence of the global market has fundamentally changed the way economic development and financial developments are understood. Neoliberalism has brought to the forefront the problems of underdeveloped and third world countries to grow their local economies and sustain basic standards of living. As the problems created by globalization become more prevalent scholars and development theorists have searched for solutions to the sustainable development impasse. Microfinance has become a new piece to the puzzle by introducing economic methods from the bottom up, with the theory that fostering local economic development will result in macro-economic development and foster integration into the global market. With the emphasis on microfinance's ability to result in macro-economic changes, many development organizations were eager to perpetuate and grow microfinance in the developing

\footnotetext{
${ }^{181}$ Id. Discredited by Les Newby "Sustainable Local Economic Development: A New Agenda for Action?" Local Environment 4, no. 1 (1999), 67.

${ }^{182}$ Les Newby, "Sustainable Local Economic Development: A New Agenda for Action?" Local Environment 4, no. 1 (1999), 67-69.
} 
world. This was done through instituting the best practices model of microfinance, which created institutional mimicry throughout the industry and, as this dissertation argues, actually hinders the MFIs ability to reduce poverty.

Programs of sustainable development, like microfinance, morphed into basic programs to reduce poverty. This view may not be the best way to attain sustainable development or poverty reduction. First off, this is because poverty reduction is not the same as economic development. The two terms while linked are not necessarily mutually exclusive. Poverty reduction that comes in the form of subsidies or foreign aid does not mean that the local economy is growing or creating business and job opportunities that can be sustained. Economic development on the other hand would involve an increase in GDI, as well as GDP and GNP. In order for economic development to be sustainable, it has to involve sustainable financial structures while giving credence to poverty alleviation.

The central question of this dissertation is does best practices adherence hinder poverty alleviation efforts of MFIs? This is the main question that this dissertation asked in a multitude of ways. The literature reviewed here has highlighted the different economic, socio-cultural, and political critiques the surround the adoption of the best practices model of microfinance. It has argued that economic factors like neoliberalism, debt cycles, and self-sufficiency seen though high interest rates and lending to the economically active poor and not the impoverished have resulted in microfinances' inability to attain poverty alleviation. Additionally, this literature review has highlighted how socio-cultural aspects of gender targeting and social capital creation are overemphasized and do not reflect the realities of social construction and identity in many of the countries that adopt best practices microfinance. 
Furthermore, it is highlighted how breaking from the best practices model means that institutions can adopt wider ranges of social programs that include education and support against domestic violence actually improving the ability of clients to use loans appropriately and have a wider community impact on poverty. Finally, this literature review has highlighted the political factors of local practices and international conditions. Influence has perpetuated the best practices model of microfinance creating corruption and misuse of loans. This has shown that the local political conditions are important in ultimately reducing poverty, and the mimicry of programs does not allow for adaptation to local environments. As such, many countries have sought to adopt best practices, which they deem successful microfinance policies, and therefore, are often faced with problems when implementing those policies. As such, this dissertation argues that microfinance policy can be done successfully; however, it must be done so in accordance with a best fit model of microfinance that accounts for local economic, sociocultural, and political experiences that exist with the developing world. 


\section{CHAPTER THREE}

\section{Theoretical Argument: MFIs and Poverty Alleviation}

One of the most pervasive policy problems in economic development studies has to do with poverty alleviation. While microfinance started as a poverty alleviation plan that can "inspire social and economic revolutions," it has become a device that brings banks, financial intermediation organizations, and governments together to solve underdevelopment and poverty. ${ }^{183}$ With the potential for economic and social growth being so great from microfinance, many countries have sought to adopt similar microfinance policies. This chapter argues that the adoption of best practices across the microfinance field prevents institutions from adopting the best fit approach to development and once again makes it susceptible to the development problems that have been around for decades. The main questions to keep in mind focus on how did the best practices model become the predominate form of microfinance, and how does adherence to this model impact poverty alleviation?

This chapter will be divided into six main sections covering the economic development theories prevalent in Latin America, several questions on the fit of MFIs and development, the core theoretical arguments, a theoretical model, and hypotheses. First the theories that have shaped economic development policy in the region for decades is important in ultimately understanding why Latin America and the cases understudy specifically would adopt a best practices model microfinance. This will cover the theories used to help create social and economic development in the region, focusing on dependency, world systems, and finally neoliberal development of which microfinance is a leading development program. The next section will cover the core theoretical arguments focusing on how following neoliberal

\footnotetext{
${ }^{183}$ Khandakar Elahi and Consantine Danopoulos., "Microfinance and Third World Development: A Critical Analysis" Journal of Political and Military Sociology 32, no. 1 (Summer 2004), 63.
} 
development policies of best practices in microfinance hinder it from creating poverty alleviation as it forces MFIs to adopt policies and programs that are not tailored to their local communities. The third section will specify the variables (independent, interdependent, and dependent) in the theoretical model placing showing how the construction of microfinance institutions with best practices impacts poverty alleviation. The fourth section lays out the theoretical model. The core argument of this dissertation is that the "institutional mimicry" in which MFIs rely on the "best practices" experience simply does not fit the wider variety of realties in developing countries. The fifth section covers the hypotheses generated from the theoretical foundation. As result, it is theorized that these MFIs are less effective in alleviating poverty in their target regions. Finally, this chapter will end with a summarization of discussions presented in this chapter highlighting.

\section{Theoretical Foundations in the Broader Development Literature}

The core theoretical argument made in this dissertation is that breaking from the best practices model can result in greater poverty alleviation. The history of the international economic system has seen the transformation of liberal economic theory, as well as, propelled society into a neoliberal construction that diminishes the value of the social welfare state of the early 20th century, replacing it with a profit driven social structure that prides itself on exploiting the worker to reduce production costs. So, what has propelled this change in economic structure, labor, and societal construction? The answer lies in how the development of economic theory has related to adopted policies in many developing countries. This section will cover the three main economic development theories, including dependency, world systems theory, and neoliberalism. These theories are important to understanding how microfinance has perpetuated the best practices model and how that model became the overriding standard for poverty alleviation. 


\section{Dependency Theory}

Raul Prebisch, under the Peron regime in Argentina, began to rework the Keynesian analysis of economic development to come to terms with the experience of Latin America. Dependency theory was the first economic theory that was developed specifically for Latin America. He based his theory on what he and his colleagues at the UN Economic Commission for Latin America saw in the disparate growth between advanced industrial countries and growth in poorer countries. Dependency theory revolutionized state and market relationships, placed a greater importance on the state's ability to take over strategic sectors of the economy rationalizing import barriers, and closed economies that were in practice the realization of import substitution industrialization (ISI). ${ }^{184}$

Prebisch's theory was simplistic in its origin and described the relationships between developed and developing countries in the world economy. He argues that poor countries exported primary commodities to rich countries who would manufacture products and sell them back to the poor country. It was seen that value added by manufacturing would prevent poorer countries from earning enough from their exports to pay for their imports. ${ }^{185}$ This would make the poor developing countries in Latin America dependent on the developed economies of the first world. Prebisch would argue for import substitution policies in an effort to reduce value added problems, but in later decades would argue that it was still the inability of smaller economies to compete and develop economies of scale that prevented them from developing and therefore still left them in the position of dependency on the developed first world. Prebisch's theory suggested that the world economy was divided into an industrial center (US, Western

\footnotetext{
${ }^{184}$ Vincent Ferraro, "Dependency Theory: An Introduction," in The Development Economics Reader, ed. Giorgio Secondi (London: Routledge, 2008), pp. 58-64.

$185 \mathrm{Id}$.
} 
Europe) and a commodity-producing periphery, such as Latin America. He argued that the "terms of trade would always work against the periphery" and that international trade was not a method for development but instead was a method for exploitation. ${ }^{186}$

\section{World Systems Theory}

Economic development in Latin America is a theoretically rich area of study. All the theories aim at explaining the economic conditions and reality of development in Latin America. One theory that expands itself outside the box is the world systems theory (WST). At the core of WST is the idea that it is not enough to look at development as a relationships between certain regions but needs to take into account an entire world system. Much of dependency theory gets its core from WST. In fact, WST argues that states are bound together by exploitative relationships that are weighted in favor of nations that are more powerful. ${ }^{187} \mathrm{WST}$ attempted to explain the failure of many countries to develop and in fact make a critical argument that the world is actually divided into three regions of periphery, semi-periphery, and the core. The core is developed countries, semi-periphery is semi-industrialized countries, and periphery is poor dependent underdeveloped nations.

WST argues that the capitalist global economic system is unfair, the periphery will always be exploited, and that the idea that international organizations and governments can create a fair system is unrealistic. They argue that the inability of global governance to create a fair system means that the world system needs to be changed. WST argues that a way out of the development/poverty trap is indeed avoiding exploitative economic relations and foreign investment, while developing advanced industries locally. What WST then supports is a system

\footnotetext{
${ }^{186}$ Daniel Yergin and Joseph Stanislaw, Commanding Heights: The Battle for the World Economy (Touchstone Publishing, 2002) pp. 235.

${ }^{187}$ Christopher McAuley, "Oliver Cox and the Roots of World Systems Theory" American Capitalism: Social Thought and Political Economy in the Twentieth Century (University of Pennsylvania Press, 2006), 180
} 
of ISI. Interestingly, microfinance has the ability to escape the problems of ISI while still delivering local industrialization and growth when we take into account that Latin America is not a homogenous social or economic structure and each state is allowed to implement policy that fully takes advantage of their local industrial capabilities.

\section{Neoliberal Economic Development Theory}

The neoliberal market orientation was founded on the belief in the "positive role of markets and the ability of the market to lead to prosperity." ${ }^{188}$ Neoliberal policies follow trends that support free trade and interdependence. ${ }^{189}$ Neoliberal policies after the 1980 s markedly changed the way the market oriented with the state, and more importantly it changed the way developed and developing countries interacted. Neoliberal policies of structural adjustment replaced older policies of poverty alleviation, these policies led to developing countries shifting to a more "export-oriented industrialization." 190 This economic system created valued decentralized open markets, un-concentrated fluid capital markets and a strong antitrust tradition. ${ }^{191}$ As such, the neoliberal system tended to devalue the state allowing market forces to regulate society.

The World Trade Organization (WTO), since the General Agreement on Tariffs and Trade (GATT), has espoused policies of liberal free market and comparative advantage, while simultaneously preventing these policies from being completely successful. The continuance of trade barriers, both tariff and non-tariff kinds, has only made integration into the international trade system thorny for developing countries. There is no doubt that inequalities exist, and the

\footnotetext{
${ }^{188}$ Robert O’Brien, and Marc Williams. 2007. Global Political Economy: Evolutions and Dynamics $2^{\text {nd }}$ ed. (Palgrave McMillian Publishing), 19.

${ }^{189}$ O'Brien and Williams., 24.

${ }^{190}$ O'Brien and Williams., 312. This shift in policy is a direct effect of the 1980 debt crisis and the Washington Consensus.

${ }^{191}$ Peter Dicken., Global Shift: Mapping the Changing Contours of the World Economy. New York: Guilford Press, 2007., 178
} 
only way for such inequalities to be changed is to address them at the level of policy implementation at the WTO. Developing countries need to use "trade reform and capacitybuilding as tools of growth and poverty reduction." ${ }^{\prime 192}$ It is no longer rational to push policies of trade liberalization without taking into account the different levels of development that each country endures. Open trade is no longer the single component to development strategies. While the history of the modern international economy has linked free trade with economic growth, for developing countries the shocks of integration into the open international economy has not provided them with the political support to maintain this free trade system. ${ }^{193}$ While barriers hinder integration, the question arises that if these barriers were cut, would developing economies experience economic growth.

The neoliberal surge in contemporary Latin American economic policies reinforces the institutionalists focus and issues of path dependency. What makes Latin America different in the context of economic development is that while there has theoretically been an overall decline in neoliberalist driven policy, Latin America seems to continue to structure its policies in this manner despite the uneven economic results of neoliberalism. As the World Bank and IMF picked up microfinance programs and started to push that as the way forward, their desire for replicability and establishing best practices meant that they were creating the same problems that structural adjustment polices had created in that they were still not taking into account local political, social, or cultural realities into account. The failure to consider local conditions is the core theoretical argument of this dissertation, and is highlighted in the next section that addresses all theoretical questions.

\footnotetext{
${ }^{192}$ Mike Moore., A World Without Walls: Freedom, Development, Free Trade and Global Governance. (Cambridge: University Press, 2003), 167.

${ }^{193}$ Paul Hirst, “The Global Economy-Myths and Realities" International Affairs 73, no. 3 (July 1997), 425.
} 


\section{The Fit of MFIs in Development Models: Four Questions}

At the core of the theoretical questions asked in this dissertation, there is a focus on why microfinance has become the popular economic development policy of choice. In this regard it is a comparative political economy project that looks at how microfinance challenges state sovereignty and impacts overall economic growth in its quest to be the leading poverty alleviation policy in the world development paradigm. In order to answer this main question, this section will pose a sequence of four questions regarding economic policies and the adoption of microfinance in Latin America: why did statist programs not work, why did IOs (World Bank and IMF) become involved; why did MFIs emerge as an alternative type of development agency; and how did the IMF and World Bank "best practices" then constrain the MFIs?

\section{Why did earlier "statist" development programs and "import substitution" not work?}

Import substitution industrialization (ISI) as an economic theory played a huge role in Latin American economic development history. ISI is a statist policy that favors state owned enterprises and protection of domestic manufacturing by not allowing exports. You only produce what you use and reduce trading, theoretically this would mean the country was self-sufficient and did not rely on others. ISI at its core an economic theory about development by which developing countries reduce their dependence on developed countries through protecting domestic industries to make them competitive with imported goods. In theory, this would make the local economy and subsequently the state self-sufficient. ISI was profound in Latin America precisely because of their history with military populist dictators. Mexico and Brazil specifically adopted ISI policies that were based on the reconstruction models of Europe; import substitution 
was a huge part of that. ${ }^{194}$ The military regimes therefore viewed statist policies of economic development that focused on state-owned enterprises. At the same time as shifts to neoliberalism were occurring, a shift to democracy was occurring in Latin America. Consequently, ISI and statist economic policies was seen as authoritarian and had to change.

ISI was eventually seen as a poor policy for economic development because it had proven itself to create more debt for countries that followed those policies. It did not spur the growth they thought it would. This, plus globalization and the adoption of the Washington Consensus as the epitome of neoliberal economic reform that promoted market-led development strategies, drove Latin American scholars like Raul Prebisch to decry the problems of ISI in favor of neoliberal development policies. Specifically, he thought excessive government control meant an economy that could not react to economic shocks quickly enough. Additionally, in many countries ISI had actually reduced the tax base and prevented the country from providing social services, further leading to the overall increase in poverty. Then under ISI, countries were relying on inflation to bridge the gaps between government expenditure and revenue. This is overall detrimental to economic development because it reduces the wealth of the nation and indebts them to larger organizations like the WTO and IMF, as well as other countries. Lastly, ISI failed because it simply discouraged exports, which are necessary for economic growth and stability. Prebisch would argue that it was still the inability of smaller economies to compete and develop economies of scale that prevented them from developing and therefore still left them in the position of dependency on the developed first world. Prebisch's theory suggested that the world economy was divided into an industrial center (US, Western Europe) and a commodity-

\footnotetext{
${ }^{194}$ Anil Hira., "Did ISI fail and is neoliberalism the answer for Latin America? Re-assessing common wisdom regarding economic policies in the region." Brazilian Journal of Political Economy 27, no. 3 (2007): $345-$ 356.
} 
producing periphery (Latin America). In addition, this division would mean trade would always work against Latin America.

When the debt crisis hit Latin American in the 1980s, the weakness and failures of ISI became glaring and many countries began to look for a way out. The crisis was sparked by the increase in oil prices in the 1970s. Latin America was industrializing at the time and had borrowed huge amounts of money from multinational banks. The obvious solution was to appeal to the IMF for loans to rescue their failing economies. However, those loans were conditional and meant that the countries had to drop ISI in favor of neoliberal policies. The shift to neoliberalism was because ISI failed and because in order to get out of debt the IMF and World Bank implemented structural adjustment reforms that did away with statist economic policy in favor of neoliberal free trade policy. This had a resounding impact on Latin America as the debt crisis and subsequent economic restructuring meant income inequality increased, unemployment increased because of the sale of state run enterprises, and removal of subsides on goods meant prices increased into unaffordable. Neoliberal reforms are directly linked with increased inequality, poverty, and lack of access to social support via programs sponsored by the state.

\section{Why did international organizations become involved - and, at the expense of state sovereignty?}

When addressing the ability of developing economies to integrate into the international trading system, the work of the WTO is vital. It is through this organization that countries derive their trading rules. The position of developing countries in the trade system was addressed in the WTO in three different rounds of discussions the Uruguay Round (1986-1993), the Millennium Round (2000-2001), and the Doha Round (2002-Present). The WTO in these three rounds began to address the issues of trade liberalization and focused on issues of services, agricultural trade, tariffs, subsidies, competition, environmental issues, anti-dumping, as well as other barriers to 
trade. These issues were addressed in the light of the principle of comparative advantage as a way to enhance global welfare.

International organizations began to enter into Latin America development simply because they asked for help. After the debt crisis, many countries were dangerously close to bankruptcy, the international organizations thought renegotiating loans that the countries already had was better than complete default. As such, they restructured the Latin American economies shifting them to neoliberal economic reform in an effort to prevent complete collapse. Latin America had let them in and therefore their sovereignty was not necessarily violated. The impact of such a decision would be felt for decades and the Latin American economies began to be stuck in modes of dependency unable to escape because of the exact terms of their agreements during the debt crisis.

After microfinance had seem some success in Bangladesh, many Latin American countries viewed this new form of economic development as a way to get out of dependency. The adoption of microfinance in Latin America was swift, and desperate. Again, the political structures of these countries were fighting against instability in democratic process and economic collapse. Microfinance came along and promised not only development but also social capital that would further ensure democratic strength. Hindsight is $20 / 20$, when it comes to microfinance. In order to reap the benefits many Latin American countries accepted the best practices model that was exported from Bangladesh by NGOs without understanding that this would result in incomplete development and a deepening of dependency.

International organizations move to create poverty alleviation in the developing world is problematic in the sense that they do not tailor their reforms to local conditions. A prime example of this is the shift that these organizations created to neoliberal economic practices in 
Mexico. Since the 1930s land in Mexico had been held under state owned collectives, these institutions came in the 1990s with microfinance, and shifted to neoliberal reform polices where land was held by corporations and to a lesser extent individuals. This land reform created political problems in Mexico because local elites were in charge of the redistribution and often gave land to those who supported them. This patronage, coupled with land now being mostly owned by corporations meant many families were left with nothing breaking down the historical cultural and social connections that had previously existed. All this because neoliberal reform says ownership must shift from the state and collectives to the private sphere. Only the reality did not fit the local political conditions of Mexico at the time, or many other Latin American countries for that matter. As such, these neoliberal reforms left people more impoverished which has resulted in an authoritarian backlash and a further weakening of democracy in Latin America.

\section{Why did MFIs emerge, as opposed to the World Bank?}

Microfinance emerged in Latin America as a hope to break from the dependency policies that were being forced on them from the World Bank, and the IMF. The shift was precisely an effort to get away from that type of lending. However, as the microfinance industry shifted itself to neoliberalism, many Latin American countries were caught in the never-ending cycle of debt and poverty. This was created because as microfinance became unstable itself due to its own reliance on subsides and the industry was looking for a new way to protect clients from bank collapse. In order to that, they turned to the World Bank and IMF away from the less regulated NGO marketplace to create institutional self-sufficiency that would protect against economic shock. This turn in the industry coincided with the IMF and World Bank's own shifts in development policy. 
Countries in Latin America began to assist multinational companies and allowed these companies to create enclave economies. This type of economy is prevalent in Latin America and is essentially nothing more than a region that is economically different from its surroundings. However, this also means enclave economies do not create macroeconomic gains and that the benefit for the larger economy is null. These types of policies created poverty by privatizing, which resulted in pay cuts, and layoffs, cuts in government spending that reduced the social safety net, and developed new "user fees" which are essentially taxes on common goods. This meant there was a denial of services that are necessary like healthcare and clean water, high interest rates that increase unemployment, and trade liberalization that eliminated protectionism resulting in collapse of domestic economies as they shift to cheaper areas. Microfinance has the ability to combat these conditions by growing local economies that increase jobs, increase employment, decrease taxes or make people actually ably to pay them, decrease interest rates which could spur economic growth further, while providing a stream of revenue to the government to reestablish social safety nets, and in some cases microfinance can be that safety net until the government can step in. However, this is conditional on the ability of microfinance to adapt to local conditions through best fit modeling over best practices. What this would look like is a microfinance model that allowed collectivization to spur cultural and social cohesion, providing separate accounts for paying "user fees" specifically, reducing their own interest rates so only one loan is needed to create a business. This would allow local groups to use the funds properly actually creating local economies that would stream into the larger macroeconomic economy, strengthening the state sufficiently to resist dependence loans from larger organization like the IMF or World Bank. 


\section{Why did World Bank and IMF “best practices" undercut MFI performance?}

This best practices model of microfinance became embedded in Latin America as the World Bank, IMF, and USAID all recast the subsidy driven model into a commercially driven best practices model. This was seen as a way to commercialize microfinance and essentially profit off poverty alleviation programs. The basic logic behind this was that the neoliberal best practices model of microfinance was the only way to reach development goals. The core issue of why MFIs adopted best practices was the funding stream. Previous examples of subsidy driven microfinance had proven itself unstable and when debt hit these countries, many of the banks closed resulting in depression era ramifications as families lost all their life savings. The shift to best practices was a step by international organizations to prevent this from happening. However, they only knew of one way of doing this instead of subsidies and non-profit donations running MFIs they would be funded by the World Bank and the IMF. This resulted in the microfinance industry actually replicating the structural adjustment programs that these international organizations had already undertaken in the region, and had already been denounced as poverty inducing rather than poverty alleviating. MFIs could be more effective if they did not have to conform to specific neoliberal economic policies and could adjust what they do for the circumstances they operate in, following more of a best fit design than a best practices model. The hindrance here is the international organizations community reliance on neoliberal economic reform and the demand that all those who get support from them must follow these reforms. So, for microfinance institutions to not collapse they need steady funding from IOs, which in turn restrict what they can actually do and really prevent the best solutions for poverty alleviation in the region. The next section addresses this through the explanation of the core theoretical 
argument that a best fit model of microfinance would decrease poverty more than the best practices model.

\section{The Theoretical Argument: Why Neoliberal "Best Practices" Undercut the Effectiveness of MFIs}

The central theoretical argument of this project is that MFIs are more effective if they break from the best practices model as defined by the World Bank and others. This is true in two respects. The first is that MFIs are more effective if they depart from the profit driven ideology prescribed by the best practices model. The second is that if they are able to develop programs that work within their local social and cultural situations. The logic of the first is economic; the logic of the second is socio-cultural. The theoretical arguments are outlined in this section by first discussing the role of funding in the microfinance industry and how collapse of MFIs lead to the adoption of best practices. Next, this section deals with what happens when MFIs fail to recognize local political realities, and how that failure can hinder poverty alleviation. Next, this section will address issues of gender empowerment. Then this chapter will cover issues of gender and best practices. Finally, this section addresses how mimicry of microfinance stems from policy learning and lesson-drawing and how this perpetuates the best practices model of microfinance as the only acceptable model.

\section{Issues in Funding}

There is no greater issue than that of poverty. Development politics has continued to look at different ways by which states can provide for their citizens while continuing to make strides in development standards. One of the most prevalent ways is to look toward international organizations like microfinance institutions to provide the necessary capital to citizens so that they make engage in their local markets with the idea being that they would contribute to their state market and therefore build the economy from the bottom up. While microfinance 
institutions have become prevalent for this type of poverty alleviation programs, these institutions are often hindered themselves by structural and financial concerns that are placed upon them from the funding organizations. What this means is that as the IMF, World Bank, and international donors fund microfinance institutions they have expectations of seeing a return on their investments. The way that this is done is to set up these programs in a specific way as to maximize profits; this is called their best practices. The best practices dictate exactly how the institutions, regardless of country or region or even village location, must be set up and run with an emphasis on certain factors like repayment and interest on loans. The reality of the matter is that often times these institutions are unable to meet the local domestic political and social realities of the very people they are trying to help. There is a move toward more encompassing programs, however those tend to be directed by non-governmental organizations that do not have the same funding structures. Although that means they do not have the same constraints, it does mean that they do have other problems of self-sufficiency where funding could be lost and the entire program could collapse.

One of the major problems with microfinance institutions being funded with subsidies is that there are no protections for their clients in the event of collapse. MFIs that are not classified as banks do not have protection from the government, yet due to best practices, many of the MFIs have compulsory savings programs. While only banks are able to take deposits the nonbanking financial institutions, (NBFI) and NGOs still have savings programs that the clients of the institutions have to participate in so as to be approved for the loans. The savings programs can vary based on the type of institutions. When it comes to the unregulated institutions, there is no protection for clients when the institution is no longer able to support their funding or the compulsory savings programs. This is problematic because the resulting fallout from an 
institutional collapse leaves a greater burden on the local government and local officials. This is because when disasters occur, of any kind, people look toward their governments to reassure them that the bad times are not going to last and that they will be taken care of.

\section{Failures to Recognize Local Political Realities}

The failure of microfinance institutions to recognize local political realities mean that they are not able to appreciate the impact that public pressure on the government can have and how that impacts states political stability. This is even more important in unstable political regions where microfinance often operates. MFIs tend to operate in regions where political structures are weaker, there are issues of corruption and instability, and internal conflict that is breaching on collapse. This means that when MFIs that have followed the best practice of creating savings either through deposits or more likely though savings programs where a small portion of the loan is withheld to ensure that there will be a repayment of some sort. Of course the problems arise when the MFIs funding changes either through loss of subsides or a decrease of funds from the World Bank or IMF. This funding change can cause banks to collapse, like Trust Chiapas in Mexico or SKS in India. This microfinance industry was marked by expansion, coercive, and deceptive practices that were developed through best practices, all of which would eventually return the poor to a "condition of financial apartheid." 195 This occurred because the best practices methodology did not take into account the local political realities.

The previous section discussed the issues that MFIs have when funding agencies reduce funding, but an important part of the argument is how international funding organizations impact state sovereignty. When it comes to microfinance loans states have to agree to certain terms in order to gain the funds that are necessary. States often look toward international funding

\footnotetext{
${ }^{195}$ Marcus Taylor., "Freedom from Poverty is Not for Free: Rural Development and the Microfinance Crisis in Andhra Pradesh, India" Journal of Agrarian Change 11, no. 4 (October 2011), 491.
} 
organizations when they lack the internal funding and support to generate development programs that the citizens want and expect. When states are faced with issues like poverty, they often look toward other states to see what their solutions have been. This form of policy learning is how policies of replication like microfinance become so prevalent. Policy transfer occurs when countries come up against a policy need and therefore look to other countries that have had the same set of circumstances.

\section{Mimicry of Microfinance from Lesson-Drawing}

Lesson-drawing is a "political process" where there is "no assurance that a lesson drawn will be both desirable and practical." ${ }^{196}$ Policymakers can sometimes adopt policies out of haste and do not adequately tailor those programs to their countries economic, social, and political conditions. What makes policymakers do this is pressure from not only the public but from political actors that arises out of dissatisfaction over a current problem or inadequate policy. Policymakers, therefore to quell the pressure, accept the "costs of uncertainty," and adopt policies that are not adequate or appropriate. ${ }^{197}$ Uncertainty can arise from crises, political conflict, and absence of consensus, lack of information, new problems, or policy disasters. ${ }^{198}$ As such, policymakers "look to experiments" like microfinance to deal with their uncertainties.

The core of the issue with solving problems with a policy of replication is that the state is willing to overlook their own local conditions. They accept the terms of the best practices methodology of funding for microfinance because simply they have to in order to receive not only funding from the MFIs but if they want to receive funding from the World Bank or the IMF. Essentially, when states look to these international organizations to help them with their poverty

\footnotetext{
${ }^{196} \mathrm{Id}$.

197 Rose., "What is Lesson-Drawing?," 5.

198 Diane Stone., "Learning Lessons and Transferring Policy across Time, Space and Disciplines" Politics 19, no. 1 (1999), 54.
} 
problems those organizations are only supporting best practices microfinance policies, which leads to a state accepting international involvement in the functioning of the state so that they can have the conditional funding from these international organizations. Now, it is understandable to look at these international organizations and argue that conditional funding is necessary to make sure that the funds are used for poverty alleviation projects and no other corrupting functions. My central argument looks specifically at how these organizations, pushing one model of microfinance is detrimental to the core missions of microfinance, which is to help the poor out of poverty. There is a lot that goes into the poverty puzzle and it should not be solved by such a narrowed concept of development policy, instead international organizations should tailor microfinance programs to take into account local political, cultural, and social realities in which they are working.

Theoretically, it is important to highlight how autonomy shifts from the state to international organizations, and how that shift affects development. Starting in the 1930s structuralism in Latin America was began to be critiqued as a subordination to the industrialized economics of the United States and Western Europe. In the post-WWII era, policy makers fully embraced the structuralist policies of national industrialization that was thought of as a development path in Latin America that would make its nations parallel to that of the United States. At this same time as structuralism rose, the decline of export-led growth saw the failure of structuralist economic policies in the region. What occurred at this time was that import substitution industrialization produced problems with hyperinflation, debt, social unrest, rebellion, and military repression of the 1960s and 1970s. This lead to the discrediting of structuralism and lead to the growth of neoliberal economic policies. 
One of the things to be considered and which plays an important part theoretically, is that development in Latin America is constrained by certain social and political realities. The major argument of this dissertation is the development policies like microfinance need to take into account these realities so that they can effectively help the people that they are setting out to help. One of the issues deals with the local political culture and the role that elites play in their society. The way that microfinance works in Latin America is important to understand why it does not work effectively. Historically speaking institutions were set up by nonprofit NGOs that were typically modeled after the Grameen Banks. Briefly, this meant they were set up as a group lending organizations by which participants would pool the loan money and all receive a portion be collectively be responsible for paying it back. This was supposed to work by using group pressure for repayment as the collateral. These types of loans were traditionally seen by the banking industry as too high a risk. However, the group lending coupled with small loan amounts was to negate these risks. The Grameen Bank originally showed that high repayment was possible with this type of loan and this resulted in a proliferation of this lending type in the area. The idea spread to other nations as NGOs began to look for ways to improve the economic lives of impoverished nations.

\section{Defining Empowerment}

Gender has become an important aspect for the microfinance field. It has its roots in the original replication of microfinance out of Bangladesh. The World Bank, when they created the consultative group for the poor (CGAP), made loans to women a mainstay for the microfinance industry. To determine if this works to benefit women, therefore, it is important to define what is really meant by gender empowerment. It is simply not enough to espouse that microfinance 
programs create gender empowerment by providing access to credit. It is necessary to focus on what that empowerment means, and how that translates into the lives of women.

Gender empowerment can be a contested term in itself. When it comes to measuring empowerment that microfinance loans give women, it is often defined in terms of empowerment through mobility, economic security, ability to make small purchases, ability to make larger purchases, and ability to repay the loans. Hashemi, Schuler, and Riley (1996), Van Staveren (2001), Weber (2004), Montgomery (1996), Hulme (2000), Duvendack (2011), Bateman (2010), and Taylor (2012), and countless others measure empowerment in this way. Defining gender empowerment in such a limited way hides any real impact that microfinance programs could have and instead focus on the typical measures for microfinance success, that being strictly the ability to repay the loan. It is an oversimplification of empowerment that prevents it from being a useful construct.

Instead, a broader more sociologically founded definition of empowerment should be used to assess these programs. Following Charmes and Wieringa (2003), and Scott (1989), a more useful definition of empowerment would include what they term gender regimes. These regimes move beyond the binary constructs of gender and incorporate not only physical differences, but also incorporate a full range of concerns that women are faced with including socio-cultural, religious, legal and political. They argue that gender regimes create a hierarchy where "divisions are suppressed and homogenized" that in turn create embedded power formations. ${ }^{199}$ Wright (2000) hints at this failed definition of empowerment by arguing that loans to women did not necessarily increase their ability to make household decisions because often

${ }^{199}$ Jacques Charmes and Saskia Wierings, "Measuring Women's Empowerment: and assessment of the Gender-related development index and the gender empowerment measure" Journal of Human Development 4, no 3 (2003), 420. 
male members of the family control the loans. ${ }^{200}$ A more encompassing definition of empowerment should be used. Empowerment therefore should not just include the basic measures of access or participation, but instead should encompass a broader definition that incorporates women's ability to move beyond the gender regime binary and achieve equal status through equal treatment by all in society.

One of the most important measurements in women's empowerment is their ability to participate in government or political processes. Empowerment can be constructively defined as an increased participation not only at the individual level, but also at the community and state level that takes constructive action. As such, through these actions they gain power. ${ }^{201}$ Gaining such power is not easy, especially when structural barriers exist. Stevens and Morris (2001) found that in Kabwe, Zambia that the government used parasitic taxation processes to disempower women. They found that women lacked the political power to demand a shift from the tax burden for the loan programs. ${ }^{202}$ Leach and Sitaram (2002) found by looking at India that microfinance programs failed to create any meaningful political participation because men would sabotage the projects preventing women from being successful and thereby take on increased roles in decision making. They found that women in India participating in silk weaving ventures were subjected to escalating domestic violence when the business venture would fail. Montgomery (1996), Hulme (2000), Duvendack (2011), Bateman (2010), and Taylor (2012) have all had similar findings that microfinance has had modest to negligible impact on welfare

${ }^{200}$ Graham A.N. Wright, Microfinance Systems: Designing Quality Financial Services for the Poor (Zed Books: London, 2000), 23.

${ }^{201}$ Kris Stevens and John Morris, "Struggling Toward Sustainability: Considering Grassroots Development" Sustainable Development 9 (2001), 152. The definition of power itself is a contested term in politics, what is meant here by power is the ability to actively participate in the governmental structure, ie. voting, protesting, seeking political office, and the ability to challenge the status quo to legal protect civil liberties.

202 Ibid. 
and women's empowerment. ${ }^{203}$ Taylor (2012) specifically found that in India "universalized pretensions" tended to "obscure the location-specific social relations and institutional processes that produce...inequality." ${ }^{, 204}$ It is assumed that microfinance schemes and micro-loans will be able to overcome social barriers, give women control over their income, create access to markets that would give women the ability to make production related decisions, and lead to an "enhanced role in decision making in the household and community;" however, these “assumptions were not justified." 205

\section{Gender and Best Practices}

One of the core arguments of this dissertation is that best practices do not allow individual microfinance institutions to incorporate a wider array of social programs tailored to fit the realities of the societies in which they operate. Best practices is simply defined as replication of program standards that focus on repayment and transparency and a requirement of giving loans to women. The consultative groups, such as the World Bank, circulate best practices. ${ }^{206}$ The sole purpose is to provide financial services to the poor. ${ }^{207}$ The best practices that the World Bank follows are set out in the CGAP pink book and dictates the standards and programs that individual microfinance institutions have to follow in order to retain funding from the World Bank other international financial institutions like the IMF. By following best practices,

203 David Hulme.(2000), "Microdebt good for poor people? A note on the dark side of microfinance" Small Enterprise Development Studies 11, no 1, 26. R Montgomery (1996), "Disciplining or protecting the poor: Avoiding the Social Costs of Peer Pressure in Microcredit Schemes" Journal of International Development 8, no 2, $289-305$. Duvendack, M., R. Palmer-Jones, J. Copestake, L. Hooper,Y. Loke and N. Rao, 2011. What is the Evidence of the Impact of Microfinance in the Well-Being of Poor People? Social Science Research Unit EPPI-Centre, University of London. Bateman, M., 2010. Why Doesn't Microfinance Work: The Destructive Rise of Local Neoliberalism.

London: Zed Books.

${ }^{204}$ Marcus Taylor, "The Antinomies of Financial Inclusion: Debt, Distress and the Workings of Indian Microfinance" Journal of Agrarian Change 12, no. 4 (October 2012): 602.

${ }^{205}$ Fiona Leach and Shashikala Sitaram, "Microfinance and women's empowerment: a lesson from India" Development in Practice 12, no. 5 (November 2002): 578.

206 Morduch., 617-618.

${ }^{207}$ Christopher Dunford., "In Search of 'Sound Practices' for Microfinance” Journal of Microfinance ESR Review 2, no. 1 (2000): 6. 
microfinance institutions are not able to tailor their programs to local conditions and therefore limit their ability to have greater positive impacts for loan recipients. Cunningham and Stamer (2005) showed that microfinance's ability to create sustainable growth is also dependent upon its interaction with local economic development schemes. These schemes follow the basic premise that "public businesses and non-governmental sector partners should work together to foster better conditions for economic growth." ${ }^{208}$ Newby (1999) however showed that these types of programs have often been discredited for their focus on the local level of economic development because they are often constrained by national and international policies that stem from tax regimes, resource allocation, and trade agreements. ${ }^{209}$ The problem however is that global economic policies tend to be single minded in that they focus exclusively on "global trade and attracting inward investment" and tend to ignore those local level political and socio-economic factors that can lead to a program's success or failure. ${ }^{210}$

\section{The Perpetuation of the Best Practices Model}

The best practices methodology that microfinance institutions use tends to have them focus on loan repayment rather than on making successful business models with supportive programing for their clients. Part of a successful model would allow institutions to take into account the social and political realities of the regions where they are working. This would mean that institutions would be able to break from the best practices structure and adopt plans and programs that really help their clients. The previous discussion laid out how microfinance institutions lack a focus on the domestic political and social structures within which they operate

\footnotetext{
${ }^{208}$ Shawn Cunningham, and Jorg Meyer-Stamer, "Planning or Doing Local Economic Development? Problems with the Orthodox Approach to LED” Africa Insight 35, no. 4 (December 2005), 5.

${ }^{209}$ Les Newby, "Sustainable Local Economic Development: A New Agenda for Action?" Local Environment 4, no. 1 (1999), 68.

${ }^{210}$ Les Newby, "Sustainable Local Economic Development: A New Agenda for Action?” Local Environment 4, no. 1 (1999), 67.
} 
and how that can have negative consequences for the loan recipients they are intending to help. This lead to the discussion on what exactly best practices is and how they influence the institutions and the loans they give.

As previously stated microfinance started as a microcredit program in Bangladesh with the main goal of helping a few farmers pool resources and share responsibility for loans that would be used buy seeds, and improved farming equipment. The idea was to help them become self-sufficient farmers, while also giving them the capital they would need to resist economic shocks. The first loans were just that small loans and nothing more. This program, which saw some benefits for the original participants, also started a revolution in the economic development field. But why is that? How does the idea of small loans to a few farmers turn into the billion dollar industry it is today, while still professing to help clients out of poverty. Why has microfinance become popular as an economic development policy? The answer is at the very core of the central arguments presented here. It has been established that microfinance institutions do not tailor their programs to the political or social realities of the regions that they work in. The main answer lies at the heart of the international economic and development system. As more international organizations began to find legitimacy in the international realm, their way of doing things started to become standard practice. This meant that states began to lose their ability to do what was in the best interests of their people and their own economic survival.

When it comes to economic development policies there always seems to be problems. One of the most cited reasons why microfinance is the best path forward as opposed to state centered policies has to do with problems with structural adjustment programs that began in the 1950s as an ideal way for economic development. Structural Adjustment Programs (SAPs) were 
focused heavily on access to credit as the way forward. These programs were built upon the idea that development was based upon factors of economic growth and equality. These programs were designed not to take into account social or cultural issues. As such, many SAP programs saw corruption by state officials. What was obvious from these programs was the social and cultural determinates needed to be taken into account in order for development to occur. Ironically, as the World Bank and IMF picked up microfinance programs and started to push that as the way forward, their desire for replicability and establishing best practices meant that they were creating the same problems that SAPs created. They were still not taking into account local political, social, or cultural realities into account, but instead were just claiming to consider these social issues. New definitions of development need to come into existence that account for social and cultural aspects; such as, employment, health care, life expectancy, education, poverty levels, and a decent standard of living. Only by defining development by the social and cultural factors as well as the economic ones, it is possible to create a new index of development that makes poverty alleviation a possibility.

\section{Theoretical Model}

In order to gain a further understanding of how best practices hinders poverty alleviation, this section specifies the precise theoretical model employed in this dissertation. This is presented in Figure 3.1. The "independent variable" that drives the model is MFI adherence-or "institutional mimicry — to neoliberal "best practices" as required by the World Bank and the IMF. The dependent variable is impact of the MFI with respect to enhancing the livelihood of the recipients of its loans—namely, poverty alleviation. The ability to do this is affected by the set of intervening variables. These variables are factors that are affected—i.e., distorted—by the adherence to best practice imposed by the World Bank and IMF. These variables are listed in 
Figure 3.1. Box 3.2 then summarizes the how distortions that occur because of "best practices" for each of these intervening variables. The remainder of the section explains each of these as they related to poverty alleviation. These dynamics provide the logic for the general hypotheses linking best practices to poverty alleviation. These are presented at the close of this section.

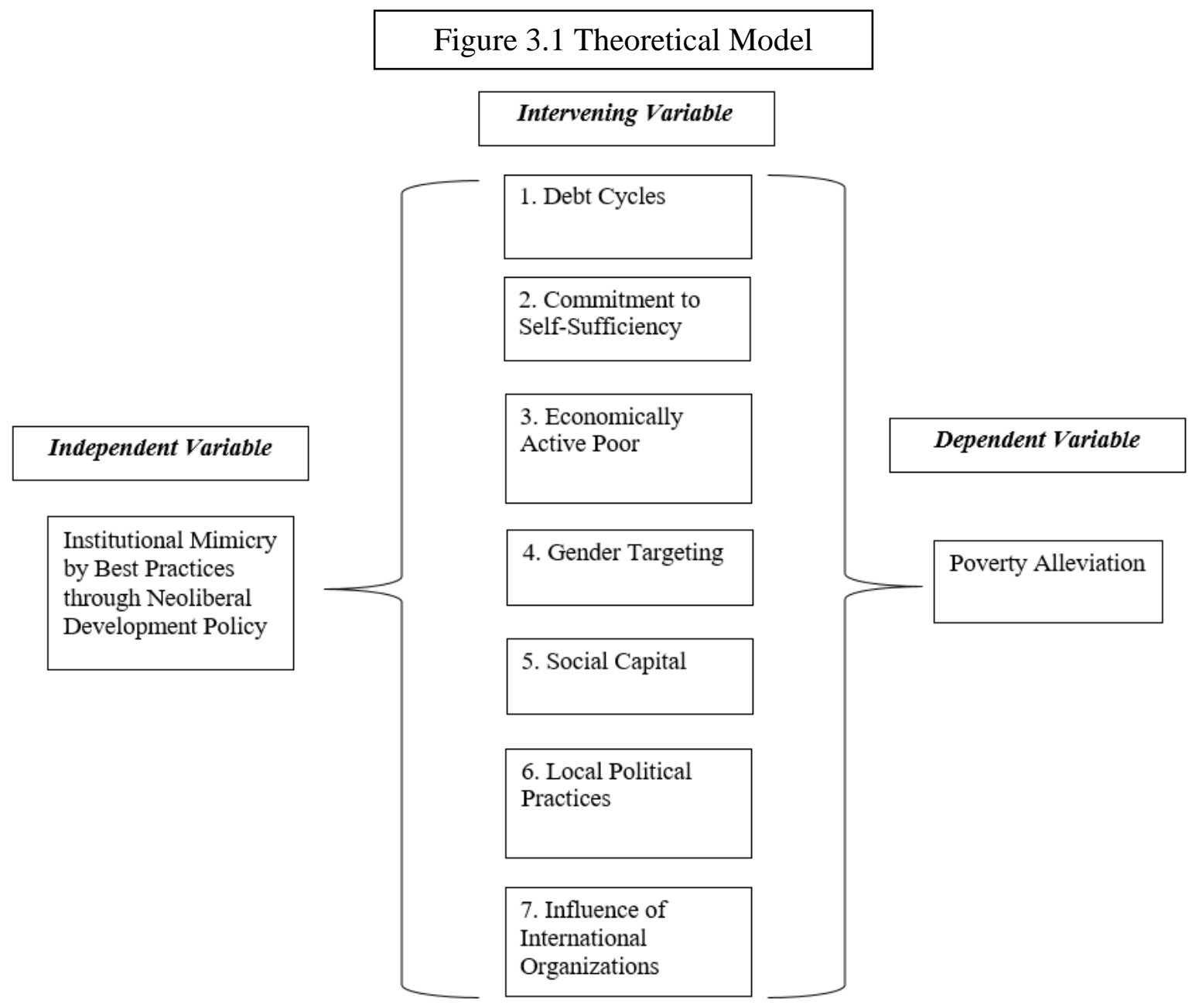


Box 3.2 Distortions that occur as a result of "best practices"

1. Debt Cycles - Access to more credit causes more debt. In addition the NGO based subsidies results in an overemphasis on loan repayment

2. Commitment to Self-Sufficiency - Cause MFIs to institute high interest rates that only make it more difficult for clients to repay loans and therefore hinders economic growth

3. Economically Active Poor - Poor v. Very Poor (By not allowing very poor to participate they do not have access to credit or savings program)

4. Gender Targeting-By focusing on women, loan programs do not take into account cultural gendered barriers to market access issues.

5. Social Capital - Commitments to group lending means that loans are not always used appropriately and therefore poverty reduction is hindered

6. Local Political Practices - Domestic regulation controls the tax scheme and therefore can create lax enforcement on repayment and also spur corruption.

7. Influence of International Organizations - Funding from IOs perpetuate the best practices model as the only way microfinance can work, but really it is focusing on failures of policy transfer that hinder poverty alleviation

The core question this dissertation proposes is how the best practices model of microfinance hinders poverty alleviation. Several components are essential to answering this question. First, best practices is the institutional model that microfinance designs itself on and consists of various components. These include the loan approval process, a variety of financial services, if they use a tool to fight poverty, if the operationally self-sufficient, if they accept deposits, if they cap the interest rate, if they limit government regulation, if they use subsides, if they have strong institutions, and if they have a performance measurement tool in place. Second, poverty alleviation is comprised of measuring schooling and education, health improvements program, gender equality, water and sanitation, housing and poverty reduction program goals, women's empowerment services, offers education services including financial, offers health services, offers gender issues training, and if the MFI offers legal services for victims of violence. This dissertation focuses on the institutional structure of MFIs, and how they can 
achieve poverty alleviation by adopting best fit policies that would allow them to tailor their programs to the local political and socio-cultural realities of the regions in which it is adopted. This is essential to the core argument that a best fit model would lead to better poverty outcomes for clients. In order to determine the institutional structures that are at play and the ability of microfinance to generate economic and social development, several intervening variables highlight how the structure of microfinance hinders development and therefore prevents poverty alleviation. The variables are creation of debt cycles, commitments to self-sufficiency, the role of the economically active poor, social capital creation, local political practices, and the influence of international organizations. All of these components of institutional design hinder microfinance from reducing poverty.

\section{Independent Variable: Institutional Mimicry through Best Practices}

The independent variable is the institutional mimicry perpetuated by best practices through neoliberal economic development policies. The commitment to neoliberal economic reforms means that microfinance institutions have to adopt the best practices model that supports neoliberal ideals of economic development. This meant that developing economies were forced to pursue neoliberal welfare policies that would foster their growth for international competition. The state would therefore switch from supporting programs of full employment to targeting programs that fostered "employability" (which microfinance is a program of employability) which were designed to reduce the welfare state and resulted in cuts to social services as well as labor, environmental, and consumer safety standards they have initiated a "race to the bottom." Neoliberal policies of structural adjustment replaced older policies of poverty alleviation. These policies led to developing countries shifting to a more export led economic model that benefited developed countries. As such, the neoliberal system tended to devalue the state allowing market 
forces to regulate society. By removing the state, the neoliberal policies followed by microfinance have ignored local political realities and only served to create more poverty as social programs were cut. A best fit model could be of a benefit because it would allow them to create the social safety net from which the state has stepped away. However, this could only occur if they rely less on neoliberal reform and more on doing what is best for the people they are trying to help.

\section{Intervening Variables: Economic, Social, Cultural and Gender Factors}

There are seven intervening variables that concern the ways in which adherence to neoliberal best practices leads to negative development outcomes. The first one looks at the current model of microfinance and how it created debt cycles that only encourage more poverty. Since microfinance's best practices model is focused on having high loan repayment, they do not stop participants from taking out multiple loans at multiple banks. The focus on repayment puts pressure on the recipient to repay the loan or face the sham of defaulting on a community level. An important part of the story here is that these zero-collateral loans use peer pressure and group formation to ensure repayment. The social communal makeup of these countries greatly favors social cohesion and communitive relationships so when faced with the inability to repay loans recipients rather take out a second loan to repay the first, instead of facing community harassment. This aspect of microfinance has often gone unnoticed expect for a few stories. However, what ends up happening in instances of failure to repay is that community harassment leads clients to suicide rather than facing the shame of default. In order to avoid this the microfinance industry through their own practices of not preventing multiple loans, allows clients to have two, three, four or sometimes more loans as each subsequent loan is used to repay the previous. They boast high repayment rates and the client gets more poverty. If microfinance, 
was to follow a best fit model then they would monitor for multiple loans and ensure that clients used the loans appropriately and had the ability to repay loans taken out.

The second intervening variable focuses on self-sufficiency. Since microfinance does focus so much on loan repayment, they also focus on operational self-sufficiency (OSS). Microfinance self-sufficiency as dictated by best practices focuses on the ability of the institution to grow by giving more loans. Typically, this is measured by the institutions ability to handle economic shock. Best practices dictate that interest rates should not be capped. High interest rates are important because that means that even if a fraction of a loan is repaid then the institution is profitable. It is not about making loans easier to repay but in fact about being able to make money off the higher interest rate loan. High interest rates are a mask for selfsufficiency. If microfinance followed a best fit model then they would cap interest rates keeping costs low for their clients. This capping would focus on poverty reduction and not being profitable.

The third intervening variable focuses on the impacts of loaning to the economically active poor over the extremely poor population. The commitment to poverty reduction is problematic when the institution is not actually focusing on the poor. Instead, the loan programs followed target the actively economic poor. The distinguishing factor here is the difference between the extremely poor and the economically active poor. Microfinance claims to help the poorest of the poor, instead they target the economically active poor, whom are able to deal with shocks when they arise because they have some resources for doing so. This distinction is important because both poor and extremely poor populations need access to financial services, however, because microfinance does not technically target the extremely poor population they do not have access to financial services they would need to protect against the economic shocks 
they would face. If microfinance was to follow a best fit model, they would support programs that focus on the poorest of the poor who exist below the minimum subsistence level, those who live in regions deprived of resources, and those who because of environment, ethnic identity, politics, and gender have little or no employment opportunities. By focusing on a best fit model of microfinance, they could have greater poverty reduction.

The fourth intervening variable concerns gender targeting and how it has become the industry standard for microfinance. Best practices dictates that microfinance loans go to women because they are often the ones who are systematically excluded from the system. However, microfinance best practices do not deal with why women are excluded from local political, economic, and social structurers. Instead, it follows the belief that all that is need for women to break the chains of bondage is a loan. This best practices approach does not focus on the sociocultural conditions that have firmly established patriarchal structures in the region instead it focuses narrowly on a perceived path out. A best fit model would address the conditions and look at why women are excluded from the marketplace. Adjust and fix the reasons for why the exclusion occurs first then help them compete economically. This would provide for greater poverty reduction because without addressing the reasons why women are excluded it ensures loans will not have the full potential for economic development. Giving someone a loan for a business does not ensure that that person could sell his or her goods in the local marketplace. This dissertation argues that adjusting to a best fit model could help women overcome those barriers.

The fifth intervening variable, social capital creation has become the backbone of microfinance. Best practices of microfinance focuses on social capital creation through their loan process. Social capital is the ideal that group lending not only ensures repayment but also 
creates trust between members. The makeup of the groups can differ and can likewise contribute to the program's success or failure. In a culture that is familial based, loan groups that are made up of random members do not have the same element of obligation. However, groups that are made up of family members can have their downfall, as these groups do not have the same element of community shame if the group goes into default. While cultural differences might not necessarily solely explain the failure of micro-credit organizations, they can create significant constraints to poverty reduction. Additionally, there is debate in the field over the ability of microfinance to create social capital. Most of this is in relation to what social capital actually is, seeing as there are many definitions. Therefore, my definition of social capital is one that would create an ideal of power from within meaning that individuals would act together. This social power would be created through "elements of production" such as knowledge, skills, and resources to increase the quality of life. Through social power, social capital is created and defined as a network of relationships that builds links between communities and groups of actors. It is in this social capital definition that I argue that a best fit model that takes into account group formation cultural aspect of society that it could create and strengthened social networking and cohesion that would lead to empowerment.

The sixth intervening variable highlights the role of local political practices. When it comes to microfinance and best practices there is no commitment to dealing with local political practices. Instead, lack of domestic regulation creates corruption, as elites are free to use lax repayment polices in order to garner more votes. This system of patronage not only hinders poverty alleviation as it only encourages more loans being flooded into the region, but it actively promotes a faulty economic system. This is seen through the mismanagement of loans where by loans are not used for business creation or economic development, but instead the loans are used 
as bribes. The lack of knowledge of local political structures hinders microfinance ability to lower poverty, because it shifts the focus away from economic development to giving out credit that it sees as profitably to the institution. It is argued that if microfinance followed a best fit model they would recognize that local regulation schemes and corruption are huge problems and would adjust their lending to only those with sound business plans and prevent the misuse of loans. Furthermore, when it comes to local political practices, best practices fail to recognize the ability of the state to create social welfare programs. Best practices assume neoliberal economic development where the state is out of social welfare, however, in severally impoverished regions social safety net are essential for poverty reduction. This dissertation argues that the best fit model would allow microfinance to step into the social safety net gap by providing funding through not only small business loans but also remittances that would allow client to improve living conditions boosting them out of poverty.

Lastly, the final intervening variable looks at the role of international organizations in microfinance as an important aspect to understanding why the best practices model is mimicked throughout Latin America in the first place. Funding from international organizations focuses solely on repayment and operational self-sufficiency and do not really focus on poverty reduction. This is the backbone of the core argument of this dissertation, international organization perpetuate the best practices model of microfinance not because it is the best model for poverty reduction but because it is the most profitable model. A best fit model of microfinance would follow a more NGO based institutional structure allowing the institution to change the programs and policies it needed to in order to best serve their clients and reduce poverty. This model does not focus on being profitable but instead goes back to the roots of microfinance and focuses on reducing poverty in the developing world. 


\section{Dependent Variable: Poverty Alleviation}

Poverty alleviation as the dependent variable includes looking at if MFIs generate programs that have social benefits, including healthcare, water and sanitation improvement, education, and educational improvement programs. All of these elements taken together (the commitments to neoliberal economic reform, creation of debt cycles, commitments to selfsufficiency, the role of the economically active poor, social capital creation, local political practices, and the influence of international organizations) highlights how microfinance has pursed the best practices model and neglected many elements that would make the institutions more successful in alleviating poverty. They form the core of this dissertations arguments that the best fit model of microfinance would be more successful in alleviating poverty than the best practices model because best practices ignores the local economic, socio-cultural, and political realities that exist in Latin America and were laid out in the previous chapter. All of these elements fit together to highlight how not only best practices hinders poverty alleviation but how the reliance on best practices generates institutional mimicry that only serves to further prevent what could be a more successful best fit model of microfinance from being adopted.

If states only adopt policies that are tailored to their specific economic, political and social conditions then why when it comes to microfinance policy states often overlook such things and follow best practices policies that are not suited to their specific state situation? In order for developing countries to adopt microfinance policies they need funding from which they have to adhere to what those funders would be considered best practices, and as such perpetuating deficient policy prescriptions for poverty alleviation. The next section highlights the hypotheses generated from this dissertations theoretical argument. 
The aim of this dissertation is to explain why and how mimicry in microfinance leads to the best practices model being adopted in developing countries without regard to their local social and political realities. This previous sections of this chapter have outlined several reasons why the perpetuation of microfinance occurs because this is a key component to understanding microfinance's failure to create poverty alleviation.

\section{Hypotheses}

Two hypotheses are generated in this section about how the best practices model of microfinance is less effective than a best fit model of microfinance would be at poverty alleviation. The institutional design of microfinance institutions has impact on two main dimensions, economic and socio-cultural. The hypotheses are generated from the impact that institutional design has on the outcomes for clients including poverty alleviation and sociocultural benefits. This also encompasses how MFIs generate empowerment for women allowing them greater autonomy in their communities, households, and the economic marketplace. Hypothesis 1: Microfinance clients are more likely to have a greater amount of economic wellbeing if the MFI does not adhere to best practices.

The more MFIs adhere to best practices the less likely they are to improve the economic wellbeing of the individual because they would be better able to address the direct needs of their clients through special programming. Individual well-being here is meant as a measure of the level of indebtedness the client has, including whether they hold multiple loans, ability to generate income to repay loans, and the ability to have access to educational and health programs.

Hypothesis 2: MFIs are more likely to address issues of patriarchy and domestic violence if they do not adhere to best practices. 
MFIs would be generally more effective if they were able to tailor their programs to local political situations addressing issues of patriarchy and corruption in a pragmatic manner. MFIs would be generally more effective if they we able to tailor programs to the communities needs addressing issues of poverty, gender, patriarchy, and violence. This is because best practices focuses narrowly on the credit access portion of microfinance programs and not on the educational and community portions of the program. A more broadly conceived program would allow for additional programs that would benefit the community and have a positive impact on poverty. This section explained the hypotheses that were generated from the core argument that best practices in microfinance hinder poverty alleviation.

\section{Summary and Conclusion}

The previous chapter has highlighted the many theoretical arguments presented in this dissertation. The core argument is that adherence to best practices results in less poverty alleviation than if the countries had used a best fit model that addressed their local economic, social, and political conditions. This chapter has reviewed the major arguments for how policy adoption and theory interact by looking at the development of import substitution and dependency, world theory systems, and most importantly neoliberal economic development theory. All of these theories lend something to the story for how we got to the best practices model of microfinance being the only model that is accepted. Next, this chapter has laid out the core theoretical arguments. While there are many to be made, this dissertation focuses on the institutional structure of microfinance as being the ultimate cause of microfinances failure to generate poverty alleviation.

The next section of this chapter showed the theoretical modeling to highlight how the intervening variables impact microfinance's ability to alleviate poverty. Finally, this chapter has 
addressed how the hypotheses have stemmed from the theoretical arguments that microfinance's best practices model is insufficient to generate poverty alleviation because it does not take into account local political issues like corrupting practices. Additionally, it ignores social conditions such as gender relations resulting from a history of patriarchy in Latin America, and how economic factors within the best practices model of lending actual prevents loans from being used appropriately and therefore creates more debt not poverty alleviation. The following chapter will highlight how these hypotheses fit into the larger methodological picture and address issues of how microfinances poverty alleviation ability is hindered through best practices.

The relationship between domestic and international politics consists of entanglements between international forces and domestic politics not only from the outside in but also from the inside out. ${ }^{211}$ When it comes to considering the interplay between economic development and state development in underdeveloped nations it is important to look at the rule by which they have to play. International organizations while they have the best intentions often fail to recognize the domestic factors by which states often find themselves constrained. Whether those factors are social, like patriarchal governing structures, or political, like corruption depends a whole lot on how the state actually is able to achieve the goals it sets out to. Additionally, there are real concerns in underdeveloped economies when it comes to helping their citizenry; namely lack of financial and actual resources. The lack of resources often times has the state looking outside itself to solve problems when its citizens put pressure on the governing structures to solve issues. There is no greater issue that that of poverty and this dissertation addresses the issues of poverty alleviation and microfinance's adherence to best practices.

\footnotetext{
${ }^{211}$ Etel Solingen., "The Global Context of Comparative Politics" in Lichback and Zucerman Comparative Politics Rationality, Culture, and Structure (Cambridge, 2009), 220.
} 


\section{Chapter Four}

\section{METHODOLOGY}

Having laid out the theoretical argument of this dissertation, I now turn to an explanation of the research design underlying the proposed empirical assessment of the best practices design of microfinance institutions. This dissertation will use a qualitative design. Qualitative analyses will center on cases studies of MFIs in Latin America. Structured focused comparison will be used to look within cases for observable implications of alternative explanations and to develop evidence to elevate one explanation over others for differences in microfinance institutional design. ${ }^{212}$ This section will explain the methodologies and the cases selected. Key here is how they vary with respect to five different aspects of best practices: type of lending institution, government regulation standards, lending type, percentage of loans to women, and poverty level of clients target for loans. Although this dissertation is concerned with the larger question of poverty elimination, the research design presented here will focus on (1) the financial status of MFI clients (e.g., indebtedness) and (2) the range of social programs, particularly for women, offered by each MFI.

This chapter is separated into three main sections. First, I will discuss the methodology this is divided into two subsections including the case study methodology and the structured focused comparison methodology. The second section lays out the institutional best practices design. The third section lays out the factors that best practices does not consider and therefore are considered part of the best fit design. This is divided into three sub-sections discussing development goals, empowerment and socio-cultural development, and the programs MFIs adopt to try to reduce poverty. The fourth main section discusses the case selection and has two main

\footnotetext{
${ }^{212}$ Sinclair., 460.
} 
sub-sections, the first discussing each of the cases briefly and the second discussing the differences between the cases. The last section includes a conclusion and summary of the methodology. The next section discusses the methodology used in this dissertation.

\section{Case Study Research Design}

This dissertation uses a case study methodology for looking at the impact of microfinance on poverty alleviation. This was done to examine closely each case and then to compare them to each other in order to evaluate the best practices/best fit approaches. This dissertation employs a case study design in order to examine the detailed institutional structure as well as the resulting policies and programs that each of the MFIs understudy adopt. By examining a handful of MFIs across Latin America, I am able to observe the effect of institutional design for clients. The core argument of this dissertation is that MFIs that depart from best practices, and adopt a wider range of programs, will have a greater impact on community economic and social development.

\section{Employing Case Study Methodology}

Case studies can hold explanatory power. Prezworski and Teune (1970) argue that generality can be achieved with the use of "system-specific indicators that serve to operationalize the same concept in distinct ways in different contexts." 213 Therefore, despite the unique effects that can be seen in individual cases, by using system specific indicators the same concept can be used to explain that effect in other cases. They argue that the field needs to have definitions of common and identical indicators to make equivalent measurements. ${ }^{214}$ This is done in this dissertation by using the categories of economic and socio-cultural development aspects,

\footnotetext{
${ }^{213}$ David Collier., "The Comparative Method" in Finifter (ed) Political Science: The State of the Discipline II (1993): 110. Also Adam Przeworski and Henry Teune., The Logic of Comparative Social Inquiry (Florida: Krieger Publishing Company, 1970), 124-130.

${ }^{214}$ Adam Przeworski and Henry Teuitne., The Logic of Comparative Social Inquiry (Florida: Krieger Publishing Company, 1970), 119.
} 
including financial services provided by each MFI and if they adopt additional program aimed at improving living standards and social development. As such, the case studies about each bank will comprise three sections that cover the following: (1) the history of the institution, (2) its adherence best practices, and (3) the ways in which the bank pursued "best fit" by deviating from best practices.

The use of in-depth case analysis is the best approach for this dissertation because it allows for the examination of why states would adopt microfinance programs designed by the World Bank. The different cases used will be three commercialized banks (Banco Sol, Compartamos, and Banco Economico), and two NGOs (IDEPRO and Pro Mujer). There are marked differences between these types of organizations. However, there are also similarities. Discussing the differences first, the most important distinction between all of them is the role of the government. In NGOs, the state government holds no regulatory body over the organization, whereas commercialized banks are subjected to regulation. The next difference is concerned with funding structures. While all MFIs have funding from international organizations like the IMF or the World Bank, NGOs additionally have funding from private companies. All institutions who receive funding, of any kind, from the World Bank or IMF must adhere to the best practices. Those institutions that also receive funding from other private or corporate sources (like NGOs) have the ability to be a bit more flexible in the programs they offer. While only banks are able to take deposits NGOs still have savings programs.

By using case study analysis, this dissertation will be able to highlight not only that following best practices is in line with the World Bank and IMF's idea of economic and social development but also that deviating from it is beneficial. There are other factors to consider when looking at the failure of microfinance to achieve positive outcomes for clients. The in- 
depth analysis will highlight the areas where microfinance institutions deviate from the international community's ideal best practices and adopt more of a best fit model to microfinance by highlighting the different policies and programs that they are able to adopt. This difference is the important part because it not only can show where different development models can be successful but it also highlights the areas why neoliberal economic development models perpetuated by the international community fail by not considering the local economic, and socio-cultural conditions in which MFIs operate. The case study methodology is the best approach to studying the institutional deign that can determine success in not only economic and social development but also poverty alleviation programs.

\section{Employing Structured Focused Comparison}

In order to understand the underlying relationship between best practices and the institutional design, I use structured focused comparison looking at the institutions policies and procedures over the course of ten years to see which policies are adopted, when and why. Structured focused comparison provides the arrangement to create causal inference from a small number of cases for the overall outcomes in the study. A structured focused comparison methodology will be used to show how the best practices model impacts microfinance institutions.

Structured focused comparison is best understood as a type of comparative methodology where focus is on the identifying the problem and then studying the variables of interest for that problem. The method is focused in that it deals with only the aspects of the cases examined that lead to being able to answer the main question asked. George and Bennett (2005), Van Evera (1997), and King, Keohane, and Verba (1994) all highlight that usefulness of structured comparison because it can clarify the impact of variables while using small-n studies. Here the 
relatively small number of cases studies can become an advantage, allowing for exactly the sorts of detailed examinations of processes needed to evaluate claims about causal mechanisms. ${ }^{215}$

For the structured focused comparison, I ask a common set of questions concerning the economic and socio-cultural impacts and more importantly if the institution follows best practices or deviates to a best fit design. The questions asked are divided into economic and socio-cultural factors. The economic questions concern levels of debt for clients, poverty levels, overindebtedness, savings mechanism, and level of operational self-sufficiency. The sociocultural questions focus on gender issues training, education, domestic violence services, access to healthcare, and available development programs. This structured comparison will ask this of all cases to get at the underlying degree to which each institution adheres to forced best practices model. In order to understand the underlying relationship between best practices and the institution program design, I will do a structured focused comparison looking at the institutions policies and procedures over the course of fifteen years to see which policies are adopted.

\section{Identifying Institutional Best Practices}

This section specifies the specific elements in the best practices model of microfinance encompass. This is important because the core argument of this dissertation is that the best practices model is less effective than a best fit model. The central independent variable in this study is the degree to which MFIs adhere to the best practices model. Best practices concerns itself with fostering the "financial sustainability of institutions that provide financial services" to the poor. ${ }^{216}$ Best practices guidelines used are set out in the World Bank's CGAP pink book. The World Bank's suggestions for best practices include, variety of financial services, client poverty

\footnotetext{
215 Alexander L. George, and Andrew Bennett. Case Studies and Theory Development in the Social Sciences. MIT Press, (2005), 67-73.

${ }^{216}$ Christopher Dunford., "In Search of 'Sound Practices' for Microfinance" Journal of Microfinance ESR Review 2, no. 1 (2000): 6.
} 
levels considered, operationally self-sufficient, use of fixed interest rate, use of subsides, measures the financial and social performance of clients, and finally loaning to women. The following highlights what the best practices are more specifically:

- Offers a Variety of Financial Services - This would include if the MFI offers, savings, mandatory savings, and insurance products, loans for household repair or educational attainment, and ATM services.

- Measures Client Poverty - If the MFI measures client poverty is part of assessing who is appropriate for gaining access to microloans. Client poverty measures are used to see what level of repayment and collateral would be necessary to reduce the risk of the loan. Therefore, MFIs' use a client poverty measure to determine who is very poor or who is economically active poor and ensure that they loan to the latter group, as they would be less risky.

- Operationally Self-Sufficient - OSS is a way to determine if the MFI is able to remain operational if subsidies or funding would be pulled. After the near collapse of the industry in the 1980s in Latin America and India, this became an important factor for institution design. The MFIs are to be able to operate off the loan repayments.

- Takes Deposits - Since MFIs have to self-sufficient, like any bank taking deposits becomes an important factor in financial solubility. This practice is encouraged so that the banks can maintain self-sufficiency. Taking deposits is also important for clients because it provides a savings mechanism for them.

- Does not Cap Interest Rates - The best practice is to not cap interest rates. This is based off neoliberal economic policies that believe the market should dictate what interest rates are. Therefore, it is in the MFIs' best interest not to cap the interest rate. 
- No Government Regulation - Government regulation is important for MFI design because best practices wants to reduce instances of corruption. However, MFIs that are full banks still have to adhere to the local regulations and tax regimes in order to take deposits. This is set up to protect the client. However, the best practice is that no regulation should be necessary.

- Does not Use Subsidies - The best practices is that the MFI should not use government or private subsidies to fund their operations or loans. The idea behind not allowing subsidies is that if those funding streams end so does the MFI and their clients could be hurt by losing their life savings. Additionally, this is used as a tool to protect the commercial MFI market and reduce competition from NGO based MFIs, which can use subsides to lower costs for clients.

- Measures Financial Outcomes - It is a best practice to measure financial outcomes of the MFI. This is part of the commitment to transparency in the field. Measuring financial outcomes allows the institutions to track their own financial stability. It does not necessarily mean tracking the financial outcomes for clients, although some institutions also have client level measures.

- Measures Social Performance - One of the best practices is to measure social performance. However, there is no direct definition of what that means; instead, the industry has taken this commitment to mean measuring the amount of loans to women, as well as the number of women on institutional decision making boards. Some MFIs go beyond that and track other development program outcomes.

- Loans to Women - This is commitment of microfinance. Therefore, as a best practices all institutions measure the amount of clients that are women. 
When microfinance institutions follow best practices they are operating within the existing global development structures, however, because some banks do in fact deviate from best practices means that it is possible for MFIs to adopt other institutional structures that may have a greater impact on economic and socio-cultural development. This section has discussed what best practices are and how the different MFIs follow or do not follow the best practices model. The next section will discuss how the MFIs fare when it comes to other socio-cultural development.

\section{Identifying Best Fit Practices}

Case study methodology will examine the impact of institutional mimicry through the forced best practices model. Additionally, it will also highlight areas where each case deviates from the best practices model and adopts a best fit design. There are three main areas where MFIs could deviate from the best practices design and accept best fit. These include (a) development goals, (b) empowerment and socio-cultural development, and (c) programs designed to reduce poverty.

\section{Determining Development Goals}

In order to study the level of poverty alleviation that microfinance institutions are able to produce a development goals are studied. The different indicators used to study if MFIs have achieved development goals include a variety of educational programs, as well as, programs to improve living conditions. The first aspect includes if the MFI had an adult education program, which would include not only financial and bookkeeping education but also includes general education programs. The second aspect of youth opportunities includes adapting services to youth clients, but also includes IT training and trauma counseling. The third second aspect is childhood schooling and education, and these included whether there was support for educational 
attainment for children that included paying of school fees. The fourth aspect of health services includes offering health insurance but also includes if they offer additional primary care services to clients. The fifth aspect of gender equality includes if they have gender issues training, if they have leadership training and if they provide services in the instances of domestic violence. The sixth aspect of water and sanitation includes if they provide funds or loans for improving household sanitation, like putting in indoor plumbing. The seventh aspect includes if they offer services for home loans that would include not only new homes but also repairs to homes. The last aspect of poverty reduction indicates whether the MFI uses a poverty reduction tool to determine the poverty level of their clients.

To determine if the different programs are effective they are compared across the cases with economic factors that could highlight that existence of the programs also results in better economic outcomes. This will also be combined with a few vignettes to highlight the programs designed to of the programs on an individual level. This will highlight how those who use the programs explain their benefits. This section has highlighted how development is addressed; the next section will discuss how empowerment is focused on by each MFI.

\section{Determining Empowerment and Socio-Cultural Development}

This section highlights how empowerment and poverty alleviation are addressed together. This is important because microfinance claims to generate empowerment for women by providing them with loans. This in turn would provide them with autonomy to make not only their own decisions but also to make more decisions in the household. However, the core argument of this dissertation is that by ignoring local social and cultural realties this empowerment is incomplete. Therefore, this section importantly lays out how this will be discussed. Empowerment is considered among several dimensions including, if the MFI offers 
women's empowerment services, offers gender issues training, and if the MFI offers legal services for victims of violence. Empowerment services would include not only gender issues training aimed at improving relationships between men and women with the goal of women having more autonomy over their decision-making. It would also include if leadership training so that women have the skills to take control of their business.

The socio-cultural program adoption aspect is important to look at because it includes additional equality and social development programs. This will allow for comparison with the best practices to see how well microfinance is achieving development goals outside of economic indicators. This also allows for the studying of wider social benefits that microfinance programs can have.

\section{Determining programs designed to Reduce Poverty}

This dissertation will study the institutional design of MFI programs in several ways. This includes looking at the economic wellbeing of individuals, as well as, socio-cultural benefits. Taken together they represent the ability of microfinance to generate poverty alleviation. First, it will look at the MFIs ability to improve the economic wellbeing of the individual. This will be done through the case studies looking at the levels of debt of each client. This will include not only poverty levels of clients, if poverty is measured by the MFI and if they track overindebtedness of clients. This will also be determined by looking at the average debt of clients and outstanding loan balances. Next development will be looked at by determining if the MFI offered a variety of financial services, as well as development driven programs that focus on public goods such as improvements to water and sanitation systems. 


\section{Case Selection and Comparisons}

This section covers the case selection process. The benefit of qualitative analysis is that it can look at not only that a policy change has occurred but also highlight the underlying functions of policymaking institutions. This allows for the study of how change occurs and impacts individuals, not just that the change occurred. This is why this study will employ qualitative methods to look at how changes in the policies of microfinance institutions came about, and what those changes had on clients. The level of analysis that this dissertation employs is on the institutional level, therefore each case selected is an existing microfinance institution.

The cases selected are from Latin America because this is where microfinance has seen a rapid growth because the World Bank and the IMF targeted after the debt crisis of the 1980s. The debt crisis exploded when Mexico announced in 1982 that it could not repay international loans and were going bankrupt. ${ }^{217}$ As a response, USAID as well as the international community through its trade policies began supporting microfinance programs in Latin America.

Microfinance defused through Latin America through various programs developed by FINCA, USAID, and IDB in Brazil, Bolivia, Columbia and Mexico all stemmed from the idea that the expansion of the informal sector would be best way for the continent to reach development goals. Bateman (2013) argues that the microfinance model was thoroughly embedded in Latin America's economy and financial system by the 1990s as significant resources began to shift to microfinance. Additionally, Bateman (2013) highlights the importance of the US and then World Bank funding for developing the microfinance sector in Latin America. ${ }^{218}$ It is for these reasons that Latin America is chosen for the case studies.

\footnotetext{
${ }^{217}$ Jean Grugel, Pia Riggirozzi, and Ben Thirkell-White. "Beyond the Washington Consensus? Asia and Latin America in search of more autonomous development." International Affairs 84, no. 3 (2008): 505.

${ }^{218}$ Milford Bateman., "The Age of Microfinance: Destroying Latin American Economies from the Bottom Up” OFSE Working Project 39 (May 2013): 5.
} 


\section{Banco Sol}

The first major breakthrough came in Bolivia when the World Bank and USAID began to look at restructuring the Bolivian economy to fall more in line with neoliberal policies by recasting the subsidy driven Grameen Bank style microfinance model to a commercially driven one. This was done by transforming the NGO PRODEM to Banco Sol. Advising on the Banco Sol transformation was the US based ACCION that was also working on many microfinance programs in South and Central America under contract to USAID. The model of microfinance that Banco Sol follows is a best practices model. It was chosen because other banks model their institutional structure after them.

\section{Compartamos}

Compartamos is an ideal MFI for this study because it is a publicly traded IPO. This means that they have to adhere to the best practices model in order to maintain not only their funding but also in order to comply with government regulations for publicly traded entities. Compartamos is also a model that is seen as the ideal model of microfinance because of its profitability, again highlighting that best practices places loan repayment and profits at the forefront of the institutional design for microfinance.

\section{Banco Economico}

Banco Economico is chosen because despite following the best practices model, on some occasions, they had to close branches that went bankrupt. This case is used to show how following the standard microfinance institutional design of best practices does not mean that the institution is successful. This is a difference from the other cases which do not have examples of institutional failure in their history and therefore this is why this case is chosen, to see why the differed in this aspect and how the institutional 1 design resulted in this closure. 


\section{Pro Mujer}

Pro Mujer is chosen because it represents an NGO version of microfinance that does not adhere to the standard institutional design. Because they do not rely on funding from the World Bank or IMF, they have more leeway in programs that they can design and develop. This case was chosen specifically for its success in adopting additional community development and social development programs. This would provide a comparative case where institutional design difference is highlighted.

\section{IDEPRO}

The Institute for the Development of the Small Productive Unit (IDEPRO) is chosen because they break from one of the major tenants of microfinance and that is that they do not loan primarily to women. Instead, they loan mostly to men. This case is chosen to see how this difference from best practices impacts the local economic and socio-cultural development. This section has briefly highlighted each case the following section will cover the differences between the cases.

\section{Comparison of the Cases}

The cases where all chosen because they are formidable MFIs in the microfinance field and vary significantly with respect to their tight adherence to "best practices" —all of which were covered in the theoretical section. Additionally, all of these cases were chosen for their differing degrees to which they follow five basic aspects of best practices including: how they are set up, how they are regulated, lending type, and percentage of loans to women, and target poverty level of clients.

The differences in cases were chosen because of the varying locations. Three of the banks are in La Paz, Bolivia, whereas, the others are in Hidalgo, Chiapas and Juarez. By selecting some 
cases that are similarly located regional differences can be controlled for and highlighted. The Mexican cases where chosen because the difference in location can highlight the difference in regional conditions. This will lend itself to the argument that mimicry prevents MFIs from altering their policies to local conditions, which would be beneficial. Additionally, the cases were chosen based on type and size. It was important to choose cases that were full-fledged banks that follow best practices rigidly and choosing NGO type MFIs that can deviate from that model. The variance in the type of MFI is important to highlighting how important deviation from the best practices model is for development outcomes. Furthermore, these banks represent a difference in state regulation, where local tax regimes and interest rate control would affect the outcomes of the clients. Governments can consider some of the micro-insurance programs offered by MFIs different from commercial products for tax purposes. ${ }^{219}$ They can also provide tax incentives for MFIs to reach poorer segments of the population. ${ }^{220}$ Some MFIs based on their design, for example credit associations, "have to follow the country’s laws and pay taxes."221

The cases were also chosen based on their lending type. While all of the banks make loans to individuals, three of them engage in group lending as well. This aspect is important because it can explain changes in social capital and community development. The cases also represent differences in the type of population that each bank loans to, whereas the only two banks that loan to those who are considered very poor (well below the poverty line), those that follow best practices more closely only lend to those who are economically active already. Therefore, these two additional cases that loan to the very poor highlight a deviation from best practices that is seen in the NGO best fit model of microfinance. The last area where there is

\footnotetext{
${ }^{219}$ Ledgerwood, et al., 76.

${ }^{220}$ Ibid., 79.

${ }^{221}$ Ibid., 175.
} 
deviation in the cases is in the area of loaning to women. While most of the bank's loan to women, IDEPRO was specifically chosen because it does not, this difference will have an explanatory impact in the sense that those banks who deviate from the best practices of loaning to women would theoretically have better community development outcomes. Table 4.1 briefly highlights each of the cases similarities and differences:

Table 4.1: Variance in Case Selection

\begin{tabular}{|c|c|c|c|c|c|}
\hline Best Practice & BancoSol & Banco & Compartamos & Pro Mujer & IDEPRO \\
\hline & & Economico & & & \\
\hline Legal Status & Bank & Bank & Bank & NGO & NGO \\
\hline Regulated & Yes & Yes & Yes & No & No \\
\hline Lending Type & Ind & Ind/SHG & Ind/SG/SHG & SHG/Ind & Ind \\
\hline $\begin{array}{l}\text { \%Loan to } \\
\text { Women }\end{array}$ & $46.55 \%$ & $50.49 \%$ & $93.76 \%$ & $94 \%$ & $36 \%$ \\
\hline $\begin{array}{l}\text { Poverty } \\
\text { Targets }\end{array}$ & Poor/Low & Poor & Poor/Low & $\begin{array}{c}\text { Very } \\
\text { Poor/Poor/Low }\end{array}$ & $\begin{array}{c}\text { Very } \\
\text { Poor/Poor/Low }\end{array}$ \\
\hline Location & Bolivia & Mexico & Mexico & Both & Bolivia \\
\hline $\begin{array}{l}\text { Gross Loan } \\
\text { Portfolio }\end{array}$ & $875,094,024$ & $881,804,570$ & $1,279,863,222$ & $\begin{array}{c}49,578,372 \\
\text { (BOL) } \\
14,299,502 \\
(\mathrm{MEX})\end{array}$ & $43,107,837$ \\
\hline No. of Clients & 275,758 & 195,063 & $2,485,029$ & $\begin{array}{l}\text { 123,394 (Bol) } \\
\text { 24,957 (Mex) }\end{array}$ & 74,106 \\
\hline
\end{tabular}

This table shows that the six different banks vary among five basic aspects of best practice. This includes whether they are a bank, non-banking financial institutions, or nongovernmental organization. Additionally, it shows that there is a difference in whether they are 
regulated by the government or not. Furthermore, the table highlights whom the banks loans to whether it be individuals, village bank (SHG), of solidarity group (SG). This table also shows the degree to which women are targeted as clients, as well as, the differing poverty level of clients. Additionally, this chart highlights variance among number of clients and loan portfolio size. This table shows that all these cases adhere to best practices in some degree and deviate in other areas. It is in the deviation that the case study design will highlight how the change impacts community economic and social development indicators.

Two cases used are Banco Sol and Compartamos because they are considered the most successful MFIs in Latin America and they were instrumental in the implementation of best practices. They are the cases used here to illustrate that MFIs do adhere closely to best practices. Three other cases are ones that have not adhered strictly to best practices and methodology. These are Pro Mujer, Banco Economico, and IDEPRO. These MFIs vary in other interesting ways. Banco Sol, Compartamos, and Banco Economico are commercialized banks, whereas Pro Mujer and IDEPRO are NGOs. Different types of MFIs were chosen to highlight the different policies that each MFI adheres to and the overall effect that the different structures would have on their programs designed to. Collectively, these Latin American cases have greatly changed the way that microfinance is understood.

What is interesting about the cases from Latin America is that government intervention can occur in different ways. The options for government intervention are as varied as the countries themselves. There are caps on interest rates, imposition on banking rules and regulation, and state-run banking. Government intervention is seen as a negative because it can artificially keep interest rates low and lead to political corruption. Hubka and Zaidi (2005) echoed this concern in their World Development Report on the Impact of Government 
Regulation on Microfinance blatantly stating, "governments should exit the microfinance sector... [and that] continued reliance on government funds is both detrimental and unrealistic." ${ }^{222}$ A review of the literature on the opposite side in Latin America does show that 29 of the 35 profitable MFI's are regulated banking institutions, and many others are pursuing licenses or some way to part of the formal financial sector. ${ }^{223}$ The literature is lacking in this area, as there are few studies that look at the current state of microfinance in Latin America and the role of the government in the industry. This project will attempt to fill this void. This section has highlighted the differences between the cases. I use these five different cases to test my hypotheses that were introduced at the end of Chapter 3, that focus on how the institutional design of microfinance impacts its ability to generate economic and socio-cultural benefits for their clients.

\section{Summary and Conclusion}

This chapter has covered the different methodology used in studying the impact that microfinance has on poverty alleviation. The case study methodology considers, first, the financial situation of clients receiving loans from each MFI and, second, the range of programs that each MFI offers focused on broader social issues and deviate from best practices to approach a best fit microfinance design. This chapter also covered the case study methodology. Finally, this chapter presented the methodological constructions of the various indexes and scales used throughout the dissertation. This chapter has laid out the foundations for measuring

\footnotetext{
${ }^{222}$ Ashley Hubka, and Rida Zaidi., ““'Impact of Government Regulation on Microfinance” Prepared for the World Development Report (2005), 1.

${ }^{223}$ Ibid., 20., Hennie van Gruening, Joselito Gallardo, and Bikki Randhawa,“A Framework for Regulating Microfinance Institutions" Financial Sector Development Department, The World Bank (December 1998): 1-41. Robert Cull., "Financial Performance and Outreach: A Global Analysis of Leading Microbanks" The Economic Journal 117 (February 2007): F107-F133.
} 
microfinance's impact in a novel way that not only allows for the study of poverty alleviation but also adds significantly to the literature on microfinance. 


\section{Chapter Five}

\section{Empirical Findings: MFI Best Practices, Poverty Alleviation, And Gender EMPOWERMENT}

At the core microfinance is the use of small loans to boost domestic economic production with an eye toward sustainable development. This project argues that because of institutional mimicry the adherence to the best practices model does not result in alleviating poverty but instead it results in over-indebtedness, baring the very poor from the financial services that they need through client targeting practices, creates more problems for women as they are the ones responsible for the debt of the microfinance loan, and spurs corruption and soaring interest rates as the domestic political systems frame the interactions between the MFIs and the state.

Demonstrating the impact of MFIs on the poverty rates of its clients and communities is beyond the scope of this dissertation's initial examination of MFIs. But, in the analyses to follow, it will be shown that adherence to best practices has a strong impact on, first, the financial well-being of its clients (e.g., their level of indebtedness to the bank) and, second, the array of programs that banks offer to deal with broader social problems and, in particular, improve the position of women clients.

Today microfinance stems from this model by creating a best practices model. The original microfinance model was successful because it was designed specifically for the conditions of Bangladesh and focused on what farmers needed in that area. This is an example of best fit microfinance. Best fit microfinance is exemplified by those institutions that depart from the 11 core principles established by the CGAP Pink Book, and are designed with their communities in mind. Microfinance best fit is an interesting approach to development practices. It is a community development scheme that simply is where community members come together to generate solutions to problems. While this is a broad definition put forth by the UN 
Development Bank, it is a foundational argument for the best fit model of microfinance. ${ }^{224}$ This highlights the idea that communities are best suited to finding the solutions for their economic development issues. For a best fit model, microfinance institutions would need to be flexible and approach development of their communities' needs. Best practices require that institutions follow the eleven principles for continued funding and program survival. A best fit model would design programs for their community as they see fit. The best fit model would include, educational programs, gender violence programs, agricultural or manufacturing programs that are appropriate, as well as healthcare and housing programs that members in impoverished countries need. This approach is best suited toward non-profit MFIs that do not rely on the neo-liberal Washington consensus economic model for funding. Best fit is exactly that, a model of development that is the best fit for the community. This dissertation seeks to highlight how institutional mimicry through best practices neoliberal economic design hinders poverty alleviation by incorporated several elements of development. These elements include economic issues of debt cycles and the impact of loaning only to the economically active poor, sociocultural issues of gender targeting and social capital creation, and finally, political issues including how international institutions push the best practices model and ignore local conditions.

This chapter is divided into three main sections. The first main section focuses on best practices and what development issues it ignores. This section includes three subsections including a discussion of best practices and the primacy of financial considerations, the failure to respond to local conditions, and finally the failure to respond to gender issues. The second

\footnotetext{
${ }^{224}$ Martin Geoghegan, and Fred Powell. 2009. "Community Development and the Contested Politics of the Late Modern Agora: of, alongside or against neoliberalism?” Community Development Journal 44, no. 4 (October): 430-447.
} 
section is comprised of the five case studies. In this section, there are three subsections for each case. The subsections cover the history of the MFIs, their adherence to the best practices model, and if they approach a best fit design. The last section is the comparative analysis of the cases, which includes a discussion of the adherence to best practices among all MFIs discussed in the case study section. This section has two subsections including economic impacts and sociocultural impacts, which also include a further subsection for each covering hypothetical assessments. In analyses that admittedly get indirectly at poverty alleviation, they consider the financial situation of each MFI bank's clients (i.e., their level of indebtedness) and the variety of social programs offered in the community. Lastly, this chapter will conclude with a summary of the arguments made and a review of the chapter. The next section will discuss best practices and microfinance design.

\section{Microfinance Institutions, Best Practices, and What Gets Ignored}

The Grameen Bank was the prototype for today’s microfinance. To reduce nonrepayment, group-lending structures were used where loans were dispersed through either the MFI or an intermediary small village bank to a group of participants. These participants then as a group were responsible for dispersing the loan to the group either through rotating turns or through dividing it among all members. The group would then be responsible for collecting the loan repayment and sending it to the MFI. The Grameen Bank originally showed that high repayment was possible with this type of loan and this resulted in a proliferation of this lending type in the area. The idea spread to other states as NGOs began to look for ways to improve the economic lives of impoverished of their citizens. The problem with this was that the original model was built upon a group lending structures. These structures relied on group pressure as collateral. 
This is an important aspect of microfinance because the industry is committing to making small loans to those in need to grow their enterprises. However, to make such loans feasible they needed to construct a collateral system. Group pressure was used to ensure loan repayment. Social collateral is seen as a "reliable measure of creditworthiness." 225 The makeup of the groups can differ and can likewise contribute to the program's success or failure. In a culture that is familial based, loan groups that are made up of random members do not have the same element of obligation. However, groups that are made up of family members can have their downfall, as these groups do not have the same element of community shame if the group goes into default. While cultural differences might not necessarily solely explain the failure of microfinance, but they can create significant constraints that can lead to the increased risk of failure. ${ }^{226}$ The ability for the group to pressure members that are not abiding by the rules is an effective method for keeping repayment rate high. It exacts measures of social stress, discernment, and instills shame for the member who willfully does not adhere to the rules and regulations. ${ }^{227}$ The use of peer pressure and peer support are most effective in groups that are self-selected because then members do not want to endure the social consequences of close friends and relatives. Group lending is still a major component in many MFIs lending structure, but the push toward commercialization has also seen an increase in lending to individuals.

After Yunus won the Noble Peace Prize, microfinance seemed to situate itself firmly within the westernized development paradigm. Commercialized microfinance became the new model after NGOs like PRODEM transformed themselves into the licensed bank Banco Sol. This

${ }^{225}$ Andrri Schoombee., "Banking for the Poor: The Successes and Failures of South African Banks" Paper Presented at DEVNET Conference on Poverty, Prosperity and Progress' (Victoria University New Zealand: 17-19 November 2000), 4.

${ }^{226}$ Aidan Hollis, and Arthur Sweetman, "Micro-credit: What can we learn from the Past?" World Development 26, no. 10 (1998), 1887.

227 Wright., 132-133. 
shift also saw the microfinance industry particularly in Latin America being run by those with banking and business background shifting away from community development schemes. ${ }^{228}$ Adams and Raymond (2008), Engler (2009), Tavanti (2013), Bateman (2014) highlighted how microfinance had become about making money from the poor, referring to microfinance institutions as moneylenders. ${ }^{229}$ This is significant because it shows that theoretically scholars are seeing the issues with the neoliberal development model that microfinance follows. Yunus has said that microfinance is a "business with a social objective, which is to help people get out of poverty." 230 In 2011, Yunus acknowledged that "microloans are designed to improve income, not add to debt burden, [and] some organizations are wrongly using microcredit... abusing the concept and creating debt." ${ }^{231} \mathrm{He}$ argued that the new commercialized model of microfinance was just transferring the volatility of the global market to the poor who are "ill equipped to handle it. ${ }^{232}$ "The commercialization of microfinance has firmly rooted itself in the development lexicon of a powerful tool to solve poverty. This section discussed microfinance design and best practices the next section will discuss the factors that the best practices model does not consider including two subsections to discuss prominent issues of local conditions and gender issues.

${ }^{228}$ Robert Christen and Deborah Drake., "Commercialization of Microfinance" Working Paper for US Agency for International Development, Bureau for Global Programs, Center for Economic Growth and Agricultural Development (October): 4-5.

${ }^{229}$ John Adams, and Frank Raymond. "Did Yunus deserve the Nobel peace prize: Microfinance or macrofarce?." Journal of Economic Issues 42, no. 2 (2008): 435-443; Mark Engler, "From Microcredit to a World Without Profit?: Muhammad Yunus Wrestles with Moving Beyond a Society Based on Greed." Dissent 56, no. 4 (2009): 81-87; Marco Tavanti, "Before microfinance: The social value of microsavings in Vincentian poverty reduction." Journal of Business Ethics 112, no. 4 (2013): 697-706.

${ }^{230}$ Muhammad Yunus, 2008. "Creating a World Without Poverty: Social Business and the Future of Capitalism” Global Urban Development Magazine 4, no. 2 (November), 29.

${ }^{231}$ Richard Hall., "'What did I do wrong?': Why the banker who helped millions of Bangladeshis out of poverty became his country's enemy number one" The Independent (October 27, 2013): Accessed: https://www.independent.co.uk/news/world/asia/what-did-i-do-wrong-why-the-banker-who-helped-millions-ofbangladeshis-out-of-poverty-became-his-8899838.html.

${ }^{232}$ Nicholas Sabin, "Microfinance: A field in flux." In Alex Nicholls, Rob Paton, and Jed Emerson, eds. Social Finance. Oxford University Press (2016), 18. 


\section{Best Fit and the Primacy of Financial Considerations}

While microfinance institutions have become prevalent for this type of poverty alleviation programs, these institutions are often hindered themselves by structural and financial concerns that are placed upon them from the funding organizations. What this means is that as the IMF and World Bank and International Donors fund microfinance institutions they have expectations of seeing a return on their investments. The way that this is done is to set up these programs in a specific way as to maximize profits; this is called their best practices. The best practices dictate exactly how the institutions, regardless of country or region or even village in which they are located, must be set up and run with an emphasis on certain factors like repayment and interest loans. The reality of the matter is that often times these institutions are often unable to meet the local domestic political and social realities of the very people they are trying to help. There is a move toward more encompassing programs, however those tend to be directed by non-governmental organizations that do not have the same funding structures and, while that means they do not have the same constraints, it does mean that they do have other problems of self-sufficiency where funding could be lost and the entire program could collapse. This section will discuss the two main areas where the best practices model comes up short, including local conditions and gender issues. Both of these things encompass socio-cultural and economic factors that are central to the theory. The economic factors that are under consideration include use of subsides, local infrastructure, and issues of government regulation. The sociocultural factors include the impact of a patriarchal society, lack of education, and the impact of domestic violence on women who participate in microfinance institutions. 


\section{Failure to Respond to Local Conditions}

Microfinance institutions failure to recognize local political realities mean that they are not able to recognize the impact that public pressure on the government can impact that states political stability, which is even more important in unstable political regions where microfinance often operates. MFIs tend to operate in regions where political structures are weaker. This means that when MFIs who have followed the best practice of creating savings either through deposits or more likely though savings programs where a small portion of the loan is withheld to ensure that there will be a repayment of some sort. Of course the problems arise when the MFIs funding changes either through loss of subsides or a decrease of funds from the World Bank or IMF. This funding change can cause banks to collapse. This microfinance industry was marked by expansion, coercive, and deceptive practices that were developed through best practices, all of which would eventually return the poor to a "condition of financial apartheid." 233 This occurred because the best practices methodology did not take into account the local political realities.

MFI's also create issues when they do not take into consideration the impact of social or cultural impacts when they ignore basic infrastructure realities. Many times microfinance loans are given to women in rural areas, and do so with little regard to how these loan recipients are going to get to the market place to trade their goods. Often time developing countries lack the physical infrastructures of roads and passageways for travel. MFIs do not provide the means for their recipients to participate in the marketplace, as that is not their concern. All MFIs are built around the core guides of best practices based on loan repayment and therefore are typically unconcerned with how they are repaid, which means they are unconcerned with how recipients' physical lack of access to the marketplaces in their communities. It was assumed that with access

\footnotetext{
${ }^{233}$ Marcus Taylor., "Freedom from Poverty is Not for Free: Rural Development and the Microfinance Crisis in Andhra Pradesh, India” Journal of Agrarian Change 11, no. 4 (October 2011), 491.
} 
to credit, women would have the ability to make their own "production related decisions." 234 Women in developing countries do not have access to the same types of infrastructure and agency as women in the developed world. There is a lack of technology and internet access that can create barriers to buy and sell directly from their own homes online, and a marketplace with access is needed to ensure enough profit to not only purchase supplies but also repay the loans. The cultural differences also include instances of women needing to be escorted to buy or sell products by male family members. ${ }^{235}$ These hidden barriers meant it was harder to actual generate a profit from the microenterprise resulting in many using household funds to repay loans. ${ }^{236}$ This also plays into the issues of how microfinance claims a commitment to not only improving the lives of women, but they also use the simplicity of loans being enough to enterprise your way out of poverty, which is a major appeal for the neoliberal economic development community. The mission drift is important because it represents how microfinance on the ground operates differently from the designed best practices. If the MFI says they want to help people out of poverty but only provide loans, then they are only doing half the job. This is why providing market access is important, because profits could be higher with a more people forward approach.

The core of the issue with solving problems with a policy of replication is that the state is willing to overlook their own local conditions. They accept the terms of the best practices methodology of funding for microfinance because simply they have to in order to receive MFI funding from the World Bank or the IMF. NGO based MFIs have similar issues, because the

\footnotetext{
${ }^{234}$ Fiona Leach, and Shashikala Sitaram. "Microfinance and women's empowerment: A lesson from India." Development in Practice 12, no. 5 (2002), 578.

235 Ibid., 581.

${ }^{236}$ John Brett, "“We sacrifice and eat less": the structural complexities of microfinance participation." Human Organization 65, no. 1 (2006): 8-19.
} 
state uses the regulatory frameworks to control foreign-funded institutions. So even though NGO based MFIs do not strictly have to follow best practices they often do to a certain degree in order to continue to operate within the state. However, NGOs that stray from the best practices are often able to adopt more programs that would help the poor. The government in some states does not always want this because they view it as taking over functions of a welfare state, which have become incompatible with the neoliberal economic development policies. Specifically, states often regulate NGO based MFIs to prevent them from crowding out the market-oriented sector. ${ }^{237}$ States can make it harder to operate a model of microfinance that strays from best practices.

Essentially, when states look to these international organizations to help them with their poverty problems, those organizations are only supporting microfinance policies to do so. This leads to a state accepting international involvement in the functioning of the state so that they can have the conditional funding from these international organizations. Now, it is understandable to look at these international organizations and argue that conditional funding is necessary to make sure that the funds are used for poverty alleviation projects and no other corrupting functions. My central argument looks specifically at how these organizations pushing one model of microfinance is detrimental to the core missions of microfinance, which is to help the poor out of poverty. There is a lot that goes into the poverty puzzle and it should not be solved by such a narrowed concept of development policy, instead international organizations should tailor microfinance programs to take into account local political, cultural, and social realities in which they are working. This section discussed issues with best practices institutional design and local conditions, the next section will discuss institutional design and gender issues.

\footnotetext{
${ }^{237}$ Ashley Hubka and Rida Zaidi., "Impact of Government Regulation on Microfinance" Prepared for the World Development Report (2005), 8.
} 


\section{Failure to Respond to Gender Issues.}

Gender issues in Latin America need to be considered when looking at how microfinance in the region works. Microfinance loans target women to mobilize a portion of the workforce that is often not engaged in the formal market. However, the loans do not address barriers to such involvement that often occur. Women in Latin America are marginalized not only in the market place but also in the home. In a culture that places great value on issues of manhood, women are often thought of as not only property but also something to be controlled. Silverberg (2014) argued that in machismo societies microfinance could create problems as women move out of the home and into work. This in turn creates a situation where domestic violence can be increased especially in the societies where it is already prevalent. ${ }^{238}$ The region's issues with machoism are not the only things at play, the region's ideas of feminism also are important. ${ }^{239}$ Microfinance institutions fail to recognize this dichotomy. MFIs commitment to women means that loans are given specifically to them, however, since the MFI is generally only concerned with repayment they often fail to teach the women how to use the loans properly.

The formal banking sector often devalued women's business in developing economies seeing them as too risky because of a lack of collateral. Microfinance then started to move into that market. They further branched out with their commitment to making loans to women. This commitment meant that they were giving loans to not only grow or sustain businesses but they were giving loans to start business. The women that would get these loans did not already need to be engaged in any sector of the market, formal or informal. This meant that loans being given

${ }^{238}$ Sarah Silverberg, "One size does not fit all: A study of microfinance practices in Peru" Undercurrent 10, no. 2 (2014), 49.

${ }^{239}$ Marrit van den Berg, Robert Lensink, and Roselia Servin "Loan officers' gender and microfinance repayment rates" The Journal of Development Studies 51, no. 9 (2015), 1241-1254. Shana Hofstetter, "The interaction of customary law and microfinance: women's entry into the world economy." Wm. \& Mary J. Women \& L. 14, no. 2 (February 2007), 337. 
to women in the hopes of establishing self-sufficiency and therefore agency were often being used as short-term crisis loans. MFIs did not realize that in many developing economies women are agents of their family life. They are the ones responsible for taking care of the children, the elderly and other aspects of supporting the family. These loans are therefore subsequently used for sending children to school, treating illnesses in the family, providing food, or fixing up the home. There are also instances where the loan is used for things other than the family, where the husband uses the loan for drinking or gambling. Regardless of what the loan is used for, the women is still responsible for paying back the loan. The burden is the responsibility of the woman who took the loan. This can lead to further problems in societies where social responsibilities are tied to the notions of reputation. Often times when women are unable to repay the loans, they flee the region in the best case or commit suicide in the worst-case scenario (this happened in Andra Pradesh India after their microfinance market collapsed). ${ }^{240}$ Part of the problems with reputation is the way the loans are made. Group lending that many microfinance organizations employ are centered on this exact type of peer pressure to ensure repayment.

Issues with gender and microfinance stem beyond the use of the loan for short-term household consumption. In regions where microfinance is prevalent, there is a lack of business infrastructure. This lack of infrastructure often means that the women who are the primary users of these loans do not receive the support or education that they need to start or grow a business. Often times in the male dominated societies in developing regions women lack basic access to

\footnotetext{
${ }^{240}$ Philip Mader., "Rise and fall of microfinance in India: The Andhra Pradesh crisis in perspective." Strategic Change 22, no. 1-2 (2013): 47-66. Soutik Biswas., "BBC News, Medak, Andhra Padesh, 'India's Microfinance Suicide Epidemic' BBC, updated 16 Dec 2010." Reporter, IB Times Staff. "54 committed suicide in AP due to microfinance debts, says SERP: report." International Business Times 29 (2010). David Hulme., "Is microdebt good for poor people? A note on the dark side of microfinance." Small Enterprise Development 11, no. 1 (2000): 26-28.
} 
the same market places that are available to men. This lack of access stems from the social and cultural ideal that men are to provide for the family by working outside the home, while women are to care for the family, including children and the elderly. Therefore, in some societies women are physically barred from common marketplaces. For example, in regions of Latin America, men control the local marketplace by deciding who gets what stall and where. Often times these community leaders do not see fit to give women access to the same space as men. Therefore, even if they could get their goods to the local market, they would find that there was no place to sell them. Additionally, those who control the space often see women's inclusion as a threat of manhood and if they do allow them to participate it is often at a heavy price; they not only demand more money for the ability to be in the marketplace, but they also demand payoffs in the terms of percentages of business revenue. ${ }^{241}$ Women who attempt to sell their goods, no matter what it is, are faced with numerous barriers for which they have no recourse. The local social structure and cultural realities in which women live means that sometimes they have no recourse from extortion of this type.

This is at the core of this dissertation's argument. MFIs that adhere strictly to the best practices ideology and are not able to adopt policies and programs that are specific to the regions local political and social realities, then the less likely the MFIs are able to be effective in their ability to help their clients out of poverty. There are further differences when it comes to MFIs that will be discussed later when analyzing the practices of the individual institutions in the case study. Microfinance institutions that offer additional programs would be more effective in

${ }^{241}$ Fiona Leach, and Shashikala Sitaram. "Microfinance and women's empowerment: A lesson from India." Development in Practice 12, no. 5 (2002), 586. Juliet Hunt, and Nalini Kasynathan. "Pathways to empowerment? Reflections on microfinance and transformation in gender relations in South Asia." Gender \& Development 9, no. 1 (2001): 42-52. 
helping their clients as well as fostering more economic and socio-cultural development. These types of institutions would offer not only training on money management and business ethics, but would also offer domestic violence and gender equity programs to their agendas. The picture is clear when it comes to microfinance loans and their impacts more needs to be done. The following discussion breaks down each of the cases and will cover issues of difficulties that MFIs have with adapting to local political and social realities and therefore their difficulty in being able to have clients use their loans effectively. This section has discussed the major effects of microfinance design with a focus on how best practices impacts local and gendered effects. The next section will be comprised of the case studies of Banco Sol, Compartamos, IDEPRO, Banco Economico, and Pro Mujer. Each case study is comprised of three subsections that discuss the history of the MFI, their adherence to best practices institutional design, and how they approach a best fit design.

\section{Case Studies of Microfinance in Latin America}

This dissertation is employing a case study methodology to highlight how the previous sections discussed effects impact the microfinance design. This section will look at each of the five cases Banco Sol, Compartamos, Banco Economico, IDEPRO, and Pro Mujer. There will also be a few vignettes to describe the MFIs impacts on clients themselves. The following section is divided into three main subsections for each case. First, the history and background will be discussed. Next, the institutions adherence to the best practices model will be covered highlighting which of the best practices they follow including; a variety of financial services, interest rates, measurement of client poverty, operational self-sufficiency, deposits, use of subsidies, role of government regulation, if the MFI measures financial outcomes, and lending to women. Lastly, each case study will discuss the MFIs movements toward a best fit design of 
microfinance — and, in particular, if MFIs offer wider arrays of programs that offer social benefits and, in particular, empower women entrepreneurs.

\section{Banco Sol}

History and Background. Banco Sol is the most replicated model of microfinance and highlights the arguments of how mimicry creates distortions and therefore hinders poverty alleviation. Banco Sol operates in La Paz Bolivia and is a commercial bank. By 1992, the positive development of the NGO led to the expansion of the institution leading to the creation of the commercial bank structure of today. Currently it has more than 160,000 clients with a portfolio of more than USD $\$ 300$ million and it has become the leading institution of microfinances. Banco Sol has formed a consulting group that assists microfinance institutions all over the world. They provided on-site technical training and transfer of micro-financial expertise and software. ${ }^{242}$ Banco Sol was chosen because it is a banking organization that adheres to state regulatory requirements. Additionally, it lends to individuals, targets the poor, and lends primarily to women.

The strategies of other MFIs were modeled after the Banco Sol's solidarity group methodology ${ }^{243}$ Banco Sol has formed a consulting group named FFP Prodem that assists microfinance institutions all over the world. FFP Prodem provides on-site technical training and transfer of micro-financial expertise and software. ${ }^{244}$ Banco Sol has perpetuated its methodology of microfinance on the field in Bolivia since then. As such, Banco Sol is an important key to why mimicry in the field of microfinance occurs and if it hinders MFI growth and sustainability. As

\footnotetext{
${ }^{242}$ Malamut., 18.

${ }^{243}$ Rhyne., 6.

${ }^{244}$ Malamut., 18.
} 
such, Banco Sol is an important key to why mimicry in the field of microfinance occurs and if it hinders MFI growth and sustainability.

Microfinance in Bolivia has gone through a boom and bust cycle. Most notable, in 19992000, there were major riots in Bolivia by borrowers against lenders, such as Banco Sol. ${ }^{245}$ The problems in Bolivia began with the economic crisis that devalued currency in Brazil. This affected Bolivia because at the time $45 \%$ of trade came from neighboring countries, which saw Bolivian export demand to decline. ${ }^{246}$ An ensuing recession spread, and Bolivia began to see demand for their exports dwindle. In response the country "cracked down on informal importing and exporting" which hit the microfinance market hard. ${ }^{247}$ The microfinance market in Bolivia at this time was characterized by heavy indebtedness and extraordinary competition. In mid-2000, clients that had loans at more than one institution held 34\% of the values of portfolios for Pro Mujer. ${ }^{248}$ According to Juan Domingo Fabbri of Banco Sol's marketing department, "clients did not see multiple loans as risky" at this time and actually thought that having several loans was a status symbol. ${ }^{249}$ In 1997, there were roughly 600,000 clients with microenterprises in Bolivia but only fifty percent of them were successfully able to sell their product. ${ }^{250}$ Clients took advantage of the credit from so many institutions and began maintain two or more loans as outstanding at a time. ${ }^{251}$ Clients began to take on more than they could handle and began using one loan to pay off another creating debt cycles that began a quick route to financial disaster for

${ }^{245}$ Elisabeth Rhyne, "Commercialization and Crisis in Bolivian Microfinance" Microenterprise Best Practices PCE-C-00-96-90004-00 (November 2001), 12

${ }^{246}$ Ibid., 12. Peter Nunnenkamp, Latin America after the currency crash in Brazil: why the optimists may be wrong. No. 337 Institute for World Economy Publishing. (1999), 9.

${ }^{247}$ Rhyne., 12.

${ }^{248}$ Rhyne., 11.

${ }^{249} \mathrm{Id}$.

${ }^{250}$ Rhyne., 11.

${ }^{251}$ Id. 
many. This overindebtedness coupled with a financial crisis resulted in a backlash against microcredit.

The crisis in Bolivia was full blown by 1999 as clients began to demand full debt forgiveness. Banco Sol and other microfinance organizations formed the new association Asofin to stop the protests and recoup their funds from debtors. While only a handful of cases were ever resolved, shortly after Asofin's creation the associations mostly collapsed throwing their own leaders in jail for illegal financial practices. ${ }^{252}$ Banco Sol has since formed a consulting group named FFP Prodem that assists microfinance institutions all over the world. FFP Prodem provides on-site technical training and transfer of microfinancial expertise and software. ${ }^{253}$ Banco Sol has perpetuated its methodology of microfinance on the field in Bolivia since then. As such, Banco Sol is an important key to why mimicry in the field of microfinance occurs and if it hinders MFI growth and sustainability.

Microfinance in Bolivia today is beginning to show similar signs to trouble that the precipitated the 1999-2000 crises. The crisis in Bolivia was the first microfinance failure and was thought to have occurred because of the impact of outside factors on the financial sector in Bolivia at the time. However, starting in 2008 , such microfinance failures began to be seen in Morocco, Nicaragua, and Pakistan, all marked by huge over-indebtedness, growing client defaults, and client withdrawals that lead the MFI's to close or merge. ${ }^{254}$ This highlights that there is some other fundamental problem in the core of the forced mimicry best practices model of microfinance.

${ }^{252}$ Rhyne., 12.

${ }^{253}$ Malamut., 18.

${ }^{254}$ Milfrd Bateman, and Ha-Joon Chang., "Microfinance and the Illusion of Development: From Hubris to Nemesis in Thirty Years" World Economic Review 1 (2012), 16. 
Adherence to Best Practices. Banco Sol has become an industry standard for how best practices is to operate within the microfinance field. In order to measure the adherence to best practices several indicators were considered. Using the CGAP Pink Book, MFI adherence to best practices was looked at through financial services for clients, if they used a poverty reduction tool, if they were operationally self-sufficient, integration into local financial institutions, if interest rates were capped, and if government intervention was limited. The use of best practices as the industry standard for microfinance tends to focus solely on economic factors, although they do make one consideration for social issues and that revolves around tools for poverty reduction and a commitment to loaning to women. All of these factors were taken into account when addressing the degree to which the microfinance institution followed best practices or not. The central argument of this dissertation revolves around the impact that following best practices has on poverty and development outcomes, with the main theoretical argument being that those institutions that deviate from best practices have a greater impact on poverty alleviation. This section will discuss the degree to which Banco Sol in Bolivia adheres to and deviates from best practices.

Banco Sol adheres to the CGAP best practices model on a majority of factors. They have evolved from the group-lending model and now $98 \%$ of their loans are made to individual clients. The majority of the loans are for urban micro-enterprises including street vendors. The average loan balance per borrower is $\$ 4190$ US while a gross national income per capita in 2018 being $\$ 3370$ USD. ${ }^{255}$ This is on the upper end of loan balance for the cases under study. While

\footnotetext{
${ }^{255}$ Copyright 2020, Microfinance Information Exchange, Inc. https://datacatalog.worldbank.org/dataset/mix-market
} 
today they have larger loans, their origin as an NGO means they started with smaller loans. The story of AM highlights this transformation:

AM started a shop business with a $\$ 60$ USD loan from PRODEM (the NGO that started Banco Sol). Over the course of five years, she took out ten loans. In addition, after the transformation to Banco Sol she took out a $\$ 5000$ USD loan to invest in a minibus for her husband's taxi service. ${ }^{256}$

The interesting aspect of this story is it reveals a multitude of issues. Not only does it highlight that clients take out multiple loans, ten in this case, but they also take out increased amounts going from $\$ 60$ to $\$ 5000$. Furthermore, it highlights an interesting aspect of the best practices models focus on loans for women. Her husband could not get the loan he needed from the institution to grow his business but she could for him. However, she would still be responsible for the loan repayment. In this instance, loaning only to women does not help him. A more encompassing design of microfinance that followed best fit could consider these factors.

Banco Sol adheres to best practices by offering a variety of financial services including savings, ATM access, debit cards, as well as financial education services. The education services provided centered on savings and using the loans for capital and entrepreneur growth. Banco Sol because of its use of common financial services to some extent has integrated itself into the financial system of the state. The use of ATM and debit cards meant that the bank could do away with its poorly operated rural branches and install services into the local community. For example, they branched out and began to build ATM services and branches into gas stations so clients could have quicker access and they could reach more people. In this sense, Banco Sol has adhered to best practices by following the standard guidelines for operation.

\footnotetext{
256 Joann. Ledgerwood, Microfinance handbook: An institutional and financial perspective. The World Bank, (1998), 116.
} 
The other factors that contribute to Banco Sol's adherence to the best practices model centers around government intervention and interest rates. They tend to follow the best practices that believe that government intervention results in corruption. Corruption is typically identified by a category of bribes, where institutions may receive lower taxes or government benefits through contracts, but also involves issues where the government uses delayed loan repayment as a method to ensure reelection. Banco Sol has limited government intervention for this reason. They also resisted (like all MFIs) government intervention because they believed it would increase taxes and instill laws about interest rates. Because Banco Sol is a regulated bank, they have to adhere to state laws about loaning, savings, assets, and interest rates. As such, when in 2013 Bolivia passed the New Banking Law (NBL), Banco Sol had to comply with the new limits on interest rates, which was to take effect in 2018. The law capped the interest rate and mandated that $60 \%$ of portfolio loans be in the productive sector. ${ }^{257}$ In this sense, government intervention was no longer limited because it mandated direct changes to the portfolio. However, because the law was not to take effect until 2018 and because Evo Morales passed it lost the election in 2019, protections for clients remained weak in the country and there was no incentive for the banks to comply with the state law. ${ }^{258}$ Banco Sol has continued to follow the industry best practices when it comes to interest rates and government intervention. Banco Sol's interest income on loan portfolio was $\$ 226,945,432$ in 2018 . Their interest rate model conforms to best practices and ensures that the bank remains financial stable. Additionally, their operational self-sufficiency (OSS) ratio was $126.99 \%$. This the ratio of operating revenues to expenses, an OSS over $100 \%$

\footnotetext{
${ }^{257}$ Rajiv Lal, and Annelena Lobb. "BancoSol and Microfinance in Bolivia." Harvard Business School Case 5165 (2016).

${ }^{258} \mathrm{Id}$.
} 
means that the bank is earning sufficient revenues to maintain stability and cover costs. ${ }^{259}$ In all of the previous factors, Banco Sol adheres to the best practices model of microfinance.

Approaching a Best Fit Design. Banco Sol is doing some things that other banks are not. They do represent a slight deviation from the best practices model in that they also offer health improvement programs and water/sanitation programs. One of the healthcare programs that they offer centers around what is becoming known as micro-insurance. Banco Sol, through Sol Salud, provides maternity coverage. Essentially, Banco Sol has entered the business of health insurance coverage, allowing clients to reduce out of pocket costs for healthcare visits. It is an innovation in the field that involves only a few institutions. Additionally, Banco Sol deviates from the best practices model by offering products and loans for household improvements that are meant to increase access to clean water and sanitation services. Because of Banco Sol's large portfolio size and stability, they are able to branch out and offer these extra services. In this regard, they are deviating from best practices. It is important to note that they are able to do this because they adhere to the best practices model in regards to financial stability, interest rates, and limited government interventions. This bank is an interesting case because they can deviate from the best practices but choose to do so not out of altruism but out of offering additional loan programs, which makes them money. It is for this reason this bank is included in the case study, as it highlights the ability of the banks to adapt to the local conditions and follow a best fit model. However it also shows that for most banks to do this they consider the financial implications and the revenue that can be made off of the additional services. The other banks in this study all adhere or deviate in similarly, with the exception of Pro Mujer, which offers the additional

\footnotetext{
${ }^{259}$ Copyright 2020, Microfinance Information Exchange, Inc. https://datacatalog.worldbank.org/dataset/mix-market
} 
services, not through loan programs but through community development programs which have no or low cost to clients.

\section{Compartamos}

History and Background. Compartamos in Juarez, Mexico is another major case providing insights into the impact of mimicry in MFI loans. Compartamos is a commercial bank. Compartamos has its origins in a Mexican youth organization developed in 1982. Gente Nueva was created to improve the quality of life for communities by providing support for health and food programs. In 1990, Compartamos was launched as a village bank that loaned to microenterprises as a pilot program in Juarez, Mexico. By 1995, it separated completely from the community level social programs and began to focus on the best practices model of microfinance with a stricter adherence to operational self-sufficiency. The social programs that started Compartamos just were not profitable for the institution continue. It operates in Oaxaca and Chiapas. Additionally, it has expanded into 32 different Mexican states. ${ }^{260}$ Today, Compartamos is one of the largest MFIs in Latin America and has become the world model for microfinance institutions because they follow the CGAP best practices model and proved to be widely profitable.

Compartamos was chosen because it is banking organization that adheres to state regulatory requirements. Additionally, it lends to individuals and groups, targets the poor low income, and lends primarily to women. Compartamos was also selected because it became one of the most replicated model of microfinance after it showed how profitable the industry could be. Additionally, it highlights the arguments of how mimicry creates distortions and therefore hinders poverty alleviation. This MFI has drastically changed the landscape of microfinance. In

${ }^{260}$ Elisabeth Rhyne, and Andres Guimon. "The Banco Compartamos initial public offering." Accion Insight 23 (2007): 1-20. 
2007, Compartamos was put up for Initial Public Offering (IPO) entering the stock market. ${ }^{261}$ When Compartamos entered the public market it saw its investors and managers make millions of dollars while their clients were charged up to $195 \%$ interest rates on their microloans. ${ }^{262}$ The commercialization of microfinance has ultimately changed the face of the microfinance mission. The MFIs were no longer focused on social missions but instead were concerned with financial sustainability and growth. The IPO offering of Compartamos saw high profile MFIs beginning to follow the Compartamos model. Compartamos is important to look at because it started the trend of commercializing microfinance after which new MFIs began to model themselves.

At the time of the IPO offering, shareholders of Compartamos was 40\% USAID and CGAP, while other minor funders like ACCION made up the rest. The primary holders of Compartamos as such, had a deep interest in neoliberal economic development and continued to shift Compartamos to the best practices model as the ideal microfinance institution. ${ }^{263}$ This began the shift to for-profit microfinance and began the debates about mission drift. Compartamos' shift away from their original development programs in health and education highlight this mission drift, and today they tend to focus on the best practices model of microfinance and continue to make returns for investors.

Adherence to Best Practices. Compartamos is an industry standard for the best practices model in microfinance. They are the most profitable MFI, and being owned by CGAP and USAID, they are the most replicated model throughout Latin America. As discussed in the previous section the best practices looked at include financial services for clients, if they used a

${ }^{261}$ Milford Bateman., "The Age of Microfinance: Destroying Latin American Economies from the Bottom Up" OFSE Working Dissertation 39 (May 2013): 5.

${ }^{262} \mathrm{Id}$. (2007), 3 .

${ }^{263}$ Richard Rosenberg, "CGAP reflections on the Compartamos initial public offering." Focus note 42 
poverty reduction tool, if they were operationally self-sufficient, integration into local financial institutions, if interest rates were capped, and if government intervention was limited. The use of best practices through Compartamos focuses on economic factors and unlike Banco Sol the private IPO means financial stability and solvency is the most important factor. These factors are taken into account when determining Compartamos' adherence to best practices and lends itself to the central argument that adherence to best practices hinders economic and socio-cultural development and the MFIs ability to generate poverty alleviation.

When it comes to microfinance in Latin America, Compartamos is the most replicated model. They adhere to best practices to a high degree on a multitude of factors. They lend to individuals and solidarity groups as well as smaller village banks. Because Compartamos is an IPO, it is a regulated bank that provides not only micro-loan services but also savings and deposit services. Therefore, Compartamos follows best practices by providing a variety of financial services. They also offer financial education services so that clients know how to properly invest in their enterprises and maximize returns on loans. They offer insurance products and payment channels as well therefore they adhere to the variety of financial services of the best practices model.

They utilize a group lending structure in order to underwrite some of their larger individual loans and mitigate collateral risks. This is an important structure in their loan process because group size is 5 to 8 women, applicants are put forth by the group and they rely on group members for screening loan suitability. Additionally, they focus on group peer pressure for loan repayment. If someone does not repay their portion of the loan in the group, they are reported for 
delinquency and typically sent to a collection agency. ${ }^{264}$ The number of outstanding loans in 2018 was $2,850,786$, with $2,485,029$ of active borrowers. They also have a loan loss rate of 9.6\%. While this means they are protected against future shocks, for comparison, the Federal Reserve recommends a loan loss rate of around $2.5 \% .{ }^{265}$ What explains the loan numbers for Compartamos? The answer lies within the best practices model. They do not cap interest rates; therefore, they can be profitable and have more loans out than active clients have. This also indicates that there is double dipping or overindebtendness where clients have more than one loan. Compartamos' interest rates are the highest in the industry at around $120 \%{ }^{266}$ Interest rates and a focus on repayment do not always benefit the clients. For example, there are several Compartamos clients who are struggling to repay loans and their comments highlight the difficulties they have had in working toward paying them off.

R.C. stated, "The truth is that I am very disappointed with this company, they extend the term and charge you a good rate of interest, apart from the weeks you have paid, they no longer count ... sorry, but it is a robbery"

K.Z.R stated, "Apart from the interest rising, they keep the payments that were given"

L.C. stated "there is no money and there is very little work, what comes out is to eat"

H.M. said of her group experience "My group renewed just because the group representative said that she had to finish her box because she wanted the loan "267

These statements about Compartamos's working with clients when it comes to repayment problems highlights that better transparency may be needed and that clients' could use more

${ }^{264}$ Angelucci, M., Karlan, D., \& Zinman, J. (2015). "Microcredit impacts: Evidence from a randomized microcredit program placement experiment by Compartamos Banco". American Economic Journal: Applied Economics, 7(1), 151-82.

${ }^{265}$ Copyright 2020, Microfinance Information Exchange, Inc. https://datacatalog.worldbank.org/dataset/mix-market

${ }^{266}$ Dylan Kevin Frawley, "Establishing an Effective Interest Rate in Latin America's Microfinance Sector: A Comparative Analysis between Mexico and Peru." Bard College Digital Commons (2019), 6.

${ }^{267}$ All quotes from https://www.facebook.com/CompartamosBanco/ in reply to Compartamos' offer to rework loans for women who could not pay. 
financial services to deal with the issues of running a micro-financed business. However, these are not aspects of the best practices model.

Compartamos also follows best practices because they loan primarily to women, and those who are classified as economically active poor. In order to maintain self-sufficiency and grow profits they do not lend to those below the poverty line. Compartamos has an operational self-sufficiency rate of $145.58 \%$. This is better than Banco Sol, which was around $120 \%{ }^{268}$ This level of OSS means that the bank has the funds to deal with economic shocks and is stable. This is a cornerstone of best practices, because they aim to prevent the bank collapses that happened in the 1980s and 1990s. Looking at the loaning programs of Compartamos highlights that it not only follows best practices, but it is best practices.

Approaching a Best Fit Design. Compartamos' gross loan portfolio is 1,279,863,222 USD. They have the largest loan portfolio of any of the cases understudy. This is important because if we look at Banco Sol in the previous section it was able to adopt other social development programs because of its large loan portfolio and profitability. Compartamos does not deviate from best practices in this way. This finding is not surprising, being that the major stakeholders of Compartamos are USAID and CGAP, which push neoliberal economic development projects. Therefore, when it comes to development goals Compartamos does the least while having the most amount of money. In fact, the only indicator on development goals that Compartamos meets is gender equity. In addition, they only meet this indicator because of their percentage of loans to women is $93.76 \%$. While they could deviate from best practices model and instill other development programs like Banco Sol that would have educational

\footnotetext{
${ }^{268}$ Copyright 2020, Microfinance Information Exchange, Inc. https://datacatalog.worldbank.org/dataset/mix-market
} 
services, or water/sanitation, or gender issues training, they do not. The lack of additional programs is highlighted by the story of Mariana:

Unexpected medical problems led to the borrowing of about \$1,160 UDS to cover an appendectomy for her son. At the time, she had four loans from four different institutions. She stated this left her "living from loan to loan."269

The reasons behind why they have not deviated could be varied, but this answers the important question asked throughout this dissertation of whether deviation from the best practices model means worse development and poverty alleviation for clients. This simply is not profitable for Compartamos to enter the private sector and they have left most of the social programs they once did follow to the original NGO that they came from.

\section{IDEPRO}

History and Background. The Institute for the Development of the Small Productive Unit (IDEPRO) was chosen because it is an NGO and therefore is not a bank. IDEPRO operates in La Paz, Bolivia. It cannot take savings and does not adhere to state regulation. It loans to individuals, lends to the very poor not just the economically active poor, and is the only bank that does not loan primarily to women. This MFI was chosen because it represents instances where it breaks from some best practices, but adheres to other best practices like organizational self-sufficiency and loan repayment. This is an interesting case because it is the only one that primarily loans to men. This is an in between case that can show how best practices impact poverty but also how the ability to stray from best practices could have greater outcomes for clients.

${ }^{269}$ Scott Graham, Julia Erickson, and Eugene Ericksen., "Over-Indebtedness in Mexico: Its Effects on Borrowers" Microfinance CEO Working Group, available at: http://microfinanceceoworkinggroup. org/, page 1718. 
IDEPRO entered the microfinance scene in Bolivia in 1991, funded by the Center for the Study of the Development of Labor and Agriculture (CEDLA). CEDLA is a private non-profit civil association that researches issues of capitalism and work, located in La Paz, Bolivia. ${ }^{270}$ IDEPRO was founded as an enterprise development organization that offers microfinance and training. It is an NGO with a different objective. It aims to strengthen the growth of mass financial business lines improving the competiveness of small producers, micro, and medium enterprises in rural and urban areas in Bolivia. IDEPRO was chosen because of its focus on enterprise development. They give individual loans toward business for the purpose of business growth. IDEPRO breaks from the best practices methodology by supplying only $36 \%$ of their loans going to women. IDEPRO and Banco Sol are the only two banks under study that loan exclusively to individuals, and therefore this case offers an interesting comparison of banking practices looking at how Banco Sol follows the best practices whereas IDEPRO breaks from it.

IDEPRO focuses on generating business in five major areas of the Bolivian economy: nuts, quinoa, textiles, lumber, and wine grapes. They tailor their lending programs to these areas because they focus on enterprise development and therefore want to focus on areas that can be successful for clients. The focus on value chains tends to make IDEPRO different from other microfinance institutions. They are designed in order to develop small farmers' ability to maintain products and sell them effectively. The success of focusing on specific crop markets is highlighted by Gonzalo Ortega and IDEPRO client of five years:

Gonzalo grows grapes for wine production on a two-hectare farm. While most IDEPRO clients use $75 \%$ percent of their land for the specified crop, he is able to use half of his land for other commercial and subsistence crops. This means that he has to work part

\footnotetext{
${ }^{270} \mathrm{http} / / /$ www.gloobal.net/iepala/gloobal/fichas/ficha.php?id=2808\&entidad=Agentes\&html=1
} 
time as a driver too. This is typical of households like his in Bolivia. What is different is that he does not have a vehicle that other farmers do. ${ }^{271}$

While this does highlight that Gonzalo is able to grow other crops on his land, the comparison he offers to other farmers and a lack of vehicle highlights that he might not be getting the most out of his loan with IDEPRO. He was one of 299 clients surveyed about growing grapes for wine production. His story shows he is able to do as he wishes with his land, but also indicates there may be a lack of services that would lead him to being able to afford a vehicle and therefore be more productive. ${ }^{272}$ This is in line with the best practices model of microfinance that does not offer additional programs or services that could have positive impacts for clients.

IDEPRO receives financial support from a wide variety of sources. As an NGO, they make most of their money off loan repayment, but they also secured a \$5 mil USD loan from the Inter-American Development Bank. The purpose was to grow loan portfolios and become more sustainable. ${ }^{273}$ They also receive funding from Oikocredit which is a financial cooperative located in the Netherlands. Oikocredit started as a church based funding institution but in 1978 began to support loans to institutions in Ecuador and India. This is a loan program and funds would have to be repaid to Oikocredit by the MFI. ${ }^{274}$ IDEPRO recognized the importance of receiving funding to support its agricultural development programs, and it has operated with

${ }^{271}$ https://globalpartnerships.org/wp-content/uploads/bsk-pdf-manager/2018/04/GP-Idepro-Case-StudyReport.pdf (Accessed July 2020), 13.

${ }^{272}$ Id.

273 "IDEPRO: Bridging the Financial Divide to Reach Small Farmers" Inter - American Development Bank. This work is licensed under a Creative Commons IGO. (2011) Accessed: https://www.google.com/url?sa=t\&rct=j\&q=\&esrc=s\&source=web\&cd=\&cad=rja\&uact=8\&ved=2ahUKEwiFx5C4 vaLqAhWBmHIEHT1QAg4QFjAAegQIBhAB\&url=https\%3A\%2F\%2Fpublications.iadb.org\%2Fen\%2Fpublicatio n\%2F16983\%2Fidepro-bridging-financial-divide-reach-small-farmers\&usg=AOvVaw0A0_cxhCVpYfx16MkS0q9I ${ }^{274}$ Accessed from https://www.oikocredit.coop/en/ June 27, 2020. 
Oikocredit in the "capital of quinoa" in Challapata, Bolivia since 1998. They have received $\$ 1,682,707.50$ USD in 2012 to support their quinoa supply chain efforts. ${ }^{275}$

Adherence to Best Practices. IDEPRO is a unique MFI in that they are the only one under study that does not lend primarily to women. Only $36 \%$ of their loan portfolio is to women. ${ }^{276}$ This case was chosen because of this deviation from the best practices model of microfinance that stresses the importance of loaning to women. This is the major deviation from the best practices model. IDEPRO's adherence to best practices was looked at through financial services for clients, if they used a poverty reduction tool, if they were operationally selfsufficient, if they were integrated into local financial institutions, if interest rates were capped, and if government intervention was limited. These are all economic factors. In fact IDEPRO only considers economic impacts when assessing their programs and their focus on agriculture and supply chains explains why they loan to not only to predominately men but also those who are deeper in poverty as agriculture is a high risk venture due to changing weather patterns. The setup of IDEPRO also follows best practices in regards to the financial services for clients. Because of their focus on supply chains, IDEPRO offers a multitude of financial services beside the loans that include financial education and in some cases advertising for products. ${ }^{277}$ Mostly they provide training to their clients on how to be competitive in the agricultural sector. This leads to a deviation for IDEPRO in that they also provide education through running training sessions about environmental impacts.

${ }^{275}$ Miles Litvinoff, and Angele Vermeulen. “OIKOCREDIT Annual Report 2013: Developing Sustainable Agricultural" Drukkerj Atlas Publishing (Netherlands, 2013), 2.

${ }^{276}$ Copyright 2020, Microfinance Information Exchange, Inc. https://datacatalog.worldbank.org/dataset/mix-market ${ }^{277} \mathrm{Id}$. 
Additionally, IDEPRO follows best practices because they do track poverty. They use the Grameen Progress out of Poverty Index. The PPI is used to determine household living characteristics as well as asset ownership. IDEPRO uses the PPI to determine who to lend to because the purpose of their loans is to increase enterprise stability they do measure the clients ability to pay back the loans. Additionally, they follow best practices through their operational self-sufficiency commitments. Their OSS is $108.61 \%$, which is the lowest OSS of the cases under study, and while they are sufficient and would be able to deal with economic shocks, a score of 108 means that major economic issues could result in bank failure. ${ }^{278}$ The lower OSS is related to the fields through which IDEPRO operates, specifically their focus on agricultural products that can be volatile.

The other indicators on which IDEPRO follows the best practices method include limited government intervention and interest rate caps. When it comes to limiting government intervention, IDEPRO is an NGO and therefore not subject to government regulation. This does mean that they are not allowed to take deposits or savings because they cannot be insured. In regards to interest rates, IDEPRO uses a declining balance interest calculation with interest rates of around $17 \%$ to $33 \%$ and most loans have the higher interest rate because they are smaller. The loaning structure for interest rates floats depending on loan size and loan risk.

Approaching a Best Fit Design. Considering deviation from the best practices model, IDEPRO does not deviate heavily; in fact, they mostly follow best practices and have a commitment to offer best practices training for long-term enterprise success. IDEPRO's gross loan portfolio is $\$ 43,107,837$ USD with a loan loss rate of $-1.98 \% .{ }^{279}$ This indicates that they

\footnotetext{
${ }^{278}$ Copyright 2020, Microfinance Information Exchange, Inc. https://datacatalog.worldbank.org/dataset/mix-market ${ }^{279} \mathrm{Id}$.
} 
have the financial stability to develop other community level projects that would deviate from the best practices model. They do not offer, any health, education, water/sanitation, housing, or gender training programs. They recover the majority of their loans and about $62 \%$ of their loan portfolio comprises of loan repayment. They serve fewer clients than most banks under study as well, at 74,106 . The capacity for increased programs exists, and this is seen through the fact that in one area where they do deviate is environmental education programs. The average loan balance per borrower is the highest among any case under study at $\$ 3,908$ USD and the highest cost per loan at $\$ 426$ USD. $^{280}$

\section{Banco Economico}

History and Background. Banco Economico was chosen because it is a bank that adheres to state regulatory requirements. Banco Economico operates in Chiapas, Mexico. Additionally, it lends to individuals and groups, targets the poor, and lends primarily to women. Banco Economico is one of the banks that follows' Compartamos' and Banco Sol models and therefore is an institution that not only adheres to best practices but also shows how mimicry in microfinance occurs. Additionally, it highlights the arguments of how mimicry creates distortions because it does not adapt to local realities. This institution highlights how the degree to which MFIs follow best practices is also important because it represents a case in which microfinance was not successful in either generating profit not helping clients.

Banco Economico was founded in 1985 with the mission of supporting small economic activities of those living in poverty. In 1991, 18 private business people launched Banco Economico as a commercialized bank. In 1997, it opened its Presto division focusing on microloans. It was profitable, generating an annual rate of return of $26.2 \%$ between 1993 and

\footnotetext{
${ }^{280}$ Copyright 2020, Microfinance Information Exchange, Inc. https://datacatalog.worldbank.org/dataset/mix-market
} 
1997. However, by October of 1999, the Presto division was closed because of changes in tax requirements and falling repayment rates. In the end, it decided that microloans were too risky. ${ }^{281}$ Banco Economico was chosen for this study because of these facts. Whereas, Compartamos and Banco Sol also commercialized banks, strengthened and grew their microfinance sector, Banco Economic stopped its operations. This case was chosen to highlight some reasons affecting the effectiveness of different types of microfinance banks.

Adherence to Best Practices. When it comes to adherence to the best practices model, Banco Economico has not only followed best practices but also mimicked the larger banks in their organizational structures. This bank was chosen because of their adherence to best practices and further leads to the core argument that following best practices results in worse outcomes for client's poverty and economic and socio-cultural development. One of the indicators that is most prevalent in the following of the best practices model is the institutional structure they offer financial services in that as a commercial bank they are regulated by the state and therefore offer loans and savings programs. They do not offer other additional services but they do have a commitment to loaning to women with $51 \%$ of their loan portfolios. Banco Economico has fewer tools for integration into the local institutions but they do operate several community level banks through which they make loans. They follow best practices on these indicators in that they focus mostly on loan and loan repayment in order to maintain the stability of the bank.

Banco Economico also follows best practices in regards to the operational selfsufficiency. They have and OSS of $115.89 \%$, which is higher than the previous case IDEPRO but lower than Compartamos and Banco Sol. ${ }^{282}$ They should be able sustain moderate economic

\footnotetext{
${ }^{281}$ Malamut., 23.

282 Copyright 2020, Microfinance Information Exchange, Inc. https://datacatalog.worldbank.org/dataset/mix-market
} 
shocks but the fact that they closed divisions after the financial crisis means that they could not. In an industry that focuses on self-sufficiency to maintain operations, the instance of bank that is commercialized not being able to survive where other institutions did is of interest. This shows that even though they follow best practices and therefore should be able to maintain the bank, they were not able to maintain their structure and have collapsed divisions when the economy goes into recessions. In addition, when we look at other indicators of best practices it should be that this bank is stable and able to move through the industry supporting poverty reduction. Further complicating the story is that in 2011 Banco Economico reported that they had 658,600 workers hired by financed enterprises. This would indicate that there was a degree of community economic development. They had a profit margin of $13.7 \%$ and financed 197,191 microenterprises in 2014. ${ }^{283}$ This bank has created jobs and opportunities for economic development, but they follow best practices and therefore they have not done well on other socio-cultural development indicators.

Banco Economico follows best practices through their interest rate structure as well. They do not cap interest rates and employ the industry standard using a declining interest rate like IDEPRO. The average cost per borrower is \$383.25 USD with an average outstanding balance of $\$ 3780$ USD. ${ }^{284}$ They have a substantial cost per borrower and maintained a profit margin, however, when it comes to offering other services Banco Economico has not been offered their clients any additional programs that would qualify as a best fit model of microfinance.

${ }^{283}$ Copyright 2020, Microfinance Information Exchange, Inc. https://datacatalog.worldbank.org/dataset/mix-market ${ }^{284} \mathrm{Id}$. 
Approaching a Best Fit Design. Of the indicators used to measure deviation from the best practices model, most focused on gender issues training, as well as development goals indicators. In order to measure development that would occur outside of the economic status, indicators of improvement in adult education, your opportunities, children's schooling, health, gender equality, water/sanitation, housing and poverty reduction tools were used. Banco Economico like the other banks that followed the best practices model (IDEPRO and Compartamos) they did not offer programs that would classify as development on these indicators. They only offered two additional programs that included a poverty tool and a gender equality tool. The use of these tools do not represent a benefit for the community, although both of those were used to classify clients and make sure that only those who could repay loans were actually accepted. This is interesting because their debt to equity ratio is one of the highest under study at 11.28. ${ }^{285}$ Capital-intensive industries like microfinance often have higher debt to equity ratios, which often use debt to finance growth. They focus so much on economic development and growth of their MFI and the basic portfolio standards are good, but they seem to finance a lot of their growth through debt, meaning that a lot of their loans come from the funding sources of the IMF and World Bank which focus on neoliberal economic development models and do not focus on community development.

Banco Economico follows the best practices model because they mimic the larger institutions structure and because they receive their funding through international organizations that require the best practices model to be followed. Yet it is possible to see that the outcomes of poverty alleviation and development of clients is lacking in this MFI. When it comes to other services for women, they do not offer services that would create socio-economic development.

\footnotetext{
${ }^{285}$ Copyright 2020, Microfinance Information Exchange, Inc. https://datacatalog.worldbank.org/dataset/mix-market
} 
When it comes to empowerment indicators that were used to measure educational services, gender issues training, legal services for domestic violence, health services, and other empowerment services. The story of Veronica highlights the need for gender issues training and domestic violence protections:

Using a loan worth \$50 UDS to purchase squash seeds, the night before harvest an expartner tried to get Veronica to sign the title of the land over to him. When she refused, he smashed the ripe crops. The loan group leader and Veronica decided not to go to the police because little would be done, and there was a fear of further retribution. For Veronica microfinance had shifted from an opportunity to a debt trap because without the crops to sell she could not possibly pay back the loan. ${ }^{286}$

Stories like this highlight the need for a further understanding of gendered relations in the countries where microfinance operates. This can give us a glimpse into the problems of the best practices model of microfinance that does not take into account issues of violence into their loan programs.

Banco Economico only had educational services, and those focused on financial literacy therefore they did not foster socio-economic development for clients. Like IDEPRO, the stricter adherence to the best practices model meant that they did not adopt extra community development programs and therefore they do not have the best indicators for poverty alleviation for clients as the poverty rate is still at $52.3 \%{ }^{287}$ Banco Economic is included in this study because they follow best practices with little if no deviation from the best practices model. Coupled with the poverty rate and the higher outstanding loan balances, it is seen that even

\footnotetext{
${ }^{286}$ Lynn Horton. Women and Microfinance in the Global South: Empowerment and Disempowerment Outcomes. (Cambridge University Press, 2017), xiii.

${ }^{287}$ Copyright 2020, Microfinance Information Exchange, Inc. https://datacatalog.worldbank.org/dataset/mix-market
} 
though they do follow best practices their ability to impact even economic development of clients is hindered. Banco Economico highlights the central argument that following best practices means that there are lower levels of economic and socio-cultural development and therefore their ability to alleviate poverty is hindered.

\section{Pro Mujer}

History and Backgorund. Pro Mujer is a nonprofit development organization dedicated to providing microfinance loans to women. Pro Mujer operates in both La Paz, Bolivia and and Hidalgo, Mexico. In 1990, Pro Mujer was founded in El Alto Bolivia by two schoolteachers, one from America one from Bolivia. They developed this MFI with the goal of improving the business skills, leadership skills, as well as improving health and human development. They were focused specifically on breaking the cycle of poverty for women. In 1996, they established Pro Mujer's International headquarters in New York City. From there, Pro Mujer moved into Nicaragua, Peru, Mexico, and Argentina. ${ }^{288}$ In 2018, they continued to expand and began to operate in Guatemala. In 2002, Pro Mujer extended their operations into Mexico in Puebla, Tlaxcala, Distrito Federal, Veracruz, Queretaro, and Oaxaca. They operate at a neighborhood center where clients can receive all the available services. ${ }^{289}$ Pro Mujer's village banking model is like Yunus' Grameen model where groups are formed and social ties are used to ensure repayment. Pro Mujer began to develop a different methodology after the financial crises that rocked Latin America in the 1980s. Carmen Velasco, the Executive Director, acknowledged that "the food and oil crises absolutely affected our clients" and decided to develop programs to help

\footnotetext{
${ }^{288}$ http://promujer.org/who-we-are/our-history/

${ }^{289}$ Marrrit van den Berg, Robert Lensink, and Roselia Serrvin., "Loan officers' gender and microfinance repayment rates." The Journal of Development Studies 51, no. 9 (2015), 1244.
} 
because "the effects [would] be very dangerous." 290 Pro Mujer's commitment to community development has them standing apart from the vast majority of MFIs and is the reason that they are chosen for this study.

Pro Mujer was chosen because it is an NGO that does not take savings and therefore does not adhere to state regulatory rules. It lends to individuals and groups, lends to the very poor and primarily women. This case was chosen because they stray the farthest from the best practices model and adopt a wide arrange of other social support programs and policies. This case represents what a best fit model could look like in practices. It not only gives out loans but is one of the few MFIs that control and keeps interest rates low. They also provide extra support for short term economic shocks that clients would experience and provide social training programs to reduce domestic violence and increase the participation of women in society. Furthermore, this case highlights the arguments of how mimicry creates distortions because it deals with the local political, social, and economic distortions that the other institutions do not, and therefore its ability to reduce poverty is greater than other types of microfinance because it breaks from the best practices model and follows more of a best fit model.

Pro Mujer is chosen for this study because with entry into each new country they have refined and adapted their programs to meet the local needs. ${ }^{291}$ They provide not only enterprise assistance, but also programs to prevent gender-based violence, educational programs, healthcare programs, and in 2017, they partnered with Microsoft to provide digital and technology skills. ${ }^{292}$ This is a significant deviation from the best practices model that the majority of MFIs' follow and represents a best fit model of microfinance. Pro Mujer as such has become one of the leading

\footnotetext{
${ }^{290}$ Sam Daley-Harrris, and Lisa Laegreid. State of the microcredit summit campaign: report 2006. Washington, DC: Microcredit Summit Campaign (2006), 32.

${ }^{291} \mathrm{http}: / /$ promujer.org/who-we-are/our-history/

$292 \mathrm{https} / / /$ promujer.org/2017/11/21/pro-mujer-microsoft-digital-skills-training/
} 
women's development social enterprises in Latin America today. I have chosen this case because they have become successful without following the stricter guidelines for microfinance that are set out in best practices. This case provides an interesting comparison to the other two larger banks of Banco Sol and Compartamos, diverting from the commercialized path following the path of social and economic development.

Adherence to Best Practices. The role of microfinance in Latin America and its impact on gender has been in the discourse for a while. What is important to remember is that microfinance in the region began through NGOs. In the 1990s there was a considerable amount of criticism among feminists that problematized the IGOs support of NGOs as magic bullets because NGOs did not support feminist ethical principles but instead collaborated with neoliberal ones. ${ }^{293}$ Even feminist NGOs were seen as supporting global neoliberal patriarchy (Alvarez 2009, Monasteiros 2006). ${ }^{294}$ NGOs boomed in Latin America in the 1990s, and microfinance was no exception. As the region's governments sought to spread the costs of social policies while cutting back state expenditures, NGOs were seen as the solution. Many of these programs, like microfinance, focused on poor urban and rural women in the name of enhancing participation in the policy process and creating social capital. The trends of NGOs in the region lead to a strong commitment to microfinance.

Pro Mujer to some extent does follow the best practices model, but they deviate the most from any other bank under study. Using the CGAP Pink Book, MFI adherence to best practices was looked at through financial services for clients, asking if they used a poverty reduction tool, if they were operationally self-sufficient, integration into local financial institutions, if interest

\footnotetext{
${ }^{293}$ Sonia Alvarez, "Beyond NGO-ization? Reflections from Latin America" Development 52, no. 2 (2009): 175-184.

${ }^{294}$ Ibid., Karin P. Monasterrios., "Bolivian women's organizations in the MAS era." NACLA Report on the Americas 40, no. 2 (2007): 33-37.
} 
rates were capped, and if government intervention was limited. Pro Mujer deviates greatly from the best practices model in their offerings of different financial services. They offer more educational programs than any other MFI, and they are the only one to offer technology training. They do follow best practices in that the offer a wide variety of loan services, that include loans to village banks and individuals as well as credit life insurance. They follow best practices in that their loan approval process does still require an evaluation of the borrower's repayment capability. They deviate from best practices here as well by conducting internal audits to household debt exposure, lending practices that violate procedures including unauthorized refinancing, multiple borrowers or co-signers per household, and other practices that could increase indebtedness. Because they are an NGO, they adhere to the idea of limited government intervention, but still follow basic regulatory guidelines of full disclosure of prices, terms, and loan conditions, as well as clear debt collection practices.

Pro Mujer also follows best practices when it comes to integration in that they support multiple village bank ventures. However, they do not adhere because they cannot take deposits so they do not always attract domestic deposits. They also adhere to best practices considering their transparency and operational self-sufficiency (OSS). Pro Mujer has an OSS of 103.56\%; while this is the lowest OSS of all the cases, they are still stable and should be able to withstand economic shocks because of their international structure. ${ }^{295}$ They also follow basic guidelines for measuring loan repayment and costs and the poverty rates of clients. For the most part Pro Mujer deviates from the best practices model.

Approaching a Best Fit Design. Pro Mujer is included in this dissertation as the example of the best fit model of microfinance because they deviate so much from the best practices model market

${ }^{295}$ Copyright 2020, Microfinance Information Exchange, Inc. https://datacatalog.worldbank.org/dataset/mix- 
that the majority of the microfinance field follows. They deviate not only in the fact that they offer a wider range of socio-cultural development programs, like healthcare and domestic violence protections, but also basic economic factors, like loan interest rates and lending practices. This section will discuss how Pro Mujer deviates from best practices and how that has better outcomes for their client's poverty.

When it comes to economic deviations, one of the most important is their interest rate structure. They have a consistent interest rate policy and use a participatory approach. They use a fixed interest rate approach meaning that the interest payment for the client will not be a surprise due to market fluctuations. As such, Pro Mujer does seek longer term financing in order to deal with market fluctuations. They have standard interest rate ranges that are consistent with the microfinance field but have some of the lowest rates at $4 \%$ to $13 \%$. Pro Mujer's mission is affordable microcredit and they do this better than any MFI under study. They also have significantly larger portfolios. In Mexico, their gross loan portfolio is $\$ 14,299,502$ USD and in Bolivia, it is $\$ 49,578,372$ USD. Despite controlling interest rates, they still are profitable. When it comes to active clients Bolivia has 123,394 and in Mexico 24,957. ${ }^{296}$ They do not have many clients in these areas, and the control interest rates meaning that their loans are more profitable. They also have some of the lowest costs per borrower ranging from \$94 USD to \$212 USD. ${ }^{297}$ As such, there is evidence that deviations from the best practices model can have positive economic impacts for clients.

Where Pro Mujer deviates from the best practices model the most, is when it comes to additional programs for their clients. Their adult education, gender training, and healthcare

\footnotetext{
${ }^{296}$ Id.

${ }^{297}$ Copyright 2020, Microfinance Information Exchange, Inc. https://datacatalog.worldbank.org/dataset/mixmarket
} 
policies are redefining what microfinance can do. Their partnership with Microsoft to offer technical training makes them a unique MFI because they recognize to lift people out of poverty it is not as simple as providing loans but the need to provide adequate training and education that can transform clients' lives is an important building piece. While this is truly revolutionary, where Pro Mujer succeeds is in the realm of healthcare. They not only offer health insurance, but they also designed their services to be a "one-stop shop" for healthcare. ${ }^{298}$ They provide basic healthcare for their clients and their children, including preventative screenings and gender specific health services. Pro Mujer's community centers not only have bank operations, and group meeting rooms, but they also have primary care consultation. This innovation in social development means that about $80 \%$ of their clients receive basic health screens for chronic conditions like obesity, high blood pressure, or diabetes. Their healthcare programs reach more than 250,000 people across different countries. ${ }^{299}$ The story of Maria highlights this benefit" Before, a doctor would only see the family if there was an illness, now thanks to Pro Mujer's integrated services both Maria and her daughters receive their annual preventative exams. ${ }^{300}$

This move into providing basic health services is a radical and welcomed deviation from the best practices model and highlights that when you develop community level programs the community thrives.

Pro Mujer also deviates from the best practices model through domestic violence prevention initiatives. They have continued to revolutionize the microfinance arena by partnering with groups like the German Agency for Technical Cooperation to provide training for how to

\footnotetext{
${ }^{298}$ Caroline Solle de Hillari. "Microinsurance: Healthy Clients" Development and Cooperation Magazine no. 11 2013, 415.

${ }^{299}$ Id.

${ }^{300} \mathrm{https}: / /$ promujer.org/2016/10/13/maria-guerrero-vargas/
} 
help victims of domestic violence while also supporting initiatives for strengthening femicide prevention laws with the aim of preventing violence against women. They are the only MFI in this study that provides counseling and legal services for victims of domestic violence. Women dealing with domestic violence has becomes an increasing issue for Pro Mujer staff. Elsa talks of the training that Pro Mujer offers:

"During training I was asked to motivate clients to fight abuse so they could move forward," she says. "I felt bad because I was preaching something I couldn't apply to my own life and I didn't know how to get out of that situation...I worked on myself so I could stand in front of them and tell them, 'you can do it. ", 301

Elsa joined Pro Mujer not necessarily for the loan program but because they did offer other services and she saw it a way forward for herself, stating that "what caught my eye the most was the Advisor's empowering work with us and the caring way in which she treated us, I remember thinking, "I want to wear a Pro Mujer shirt like hers." "302 Pro Mujer follows a best fit design because they are the only MFI that provides women's rights education to help women speak up when violence occurs. The recognition that there is more to poverty than loan access represents a significant break from the best practices model and Pro Mujer's programs not only represent what best fit microfinance would look like but also highlights that it can be done while maintaining financial stability and profitability.

Microfinance in Latin America has presented a wide variety of cases to evaluate impacts on clients. In this section, different cases were discussed to highlight how different MFIs either adhered or deviated from the neoliberal best practices model of economic development. The core argument of this dissertation is that deviation has more benefit for clients that can reduce poverty

\footnotetext{
${ }^{301}$ https://promujer.org/2016/10/13/elsa-castillo-garcia/

${ }^{302} \mathrm{Id}$.
} 
better than following the best practices model. This section has used case studies to highlight each MFIs background and adherence to best practices. The following section will look at the different MFIs comparatively. This section will begin with a discussion of best practices and a comparative analysis of the cases adherence to this model of microfinance. There are two subsections that discuss the economic impacts and socio-cultural impacts of following the best practices model.

\section{Comparative Analysis of the Five MFI Cases}

The central question in this study is the degree to which MFIs adhere to the best practices model—defined by neoliberal economic ideology—and how that affects their ability to affect economic growth and development locally. The best practices model is only concerned with financial sustainability through the replication of best practices as set out in the World Bank's CGAP pink book. The following table 5.1 highlights which best practices each bank follows.

\begin{tabular}{|c|c|c|c|c|c|}
\hline \multirow[b]{2}{*}{ Best Practice } & \multicolumn{3}{|c|}{ Table 5.1 MFIs Adherence to Best Practices } & \multirow[b]{2}{*}{ Pro Mujer } & \multirow[b]{2}{*}{ IDEPRO } \\
\hline & Banco Sol & Compartamos & Banco Economico & & \\
\hline Checks for Overindebtedness & & & & $\checkmark$ & $\checkmark$ \\
\hline Offers a Variety of Financial Services & $\checkmark$ & $\checkmark$ & $\checkmark$ & $\checkmark$ & $\checkmark$ \\
\hline Measures Client Poverty & & $\checkmark$ & $\checkmark$ & & $\checkmark$ \\
\hline Operational Self-Sufficient & $\checkmark$ & $\checkmark$ & $\checkmark$ & $\checkmark$ & $\checkmark$ \\
\hline Takes Deposits & $\checkmark$ & $\checkmark$ & $\checkmark$ & & \\
\hline Doesn't Cap Interest Rate & $\checkmark$ & $\checkmark$ & $\checkmark$ & & $\checkmark$ \\
\hline Government Regulation & $\checkmark$ & $\checkmark$ & $\checkmark$ & & \\
\hline Doesn't Use Subsidies & $\checkmark$ & $\checkmark$ & $\checkmark$ & & \\
\hline Measures Financial Outcomes & $\checkmark$ & $\checkmark$ & $\checkmark$ & $\checkmark$ & $\checkmark$ \\
\hline Measures Social Performance & & & $\checkmark$ & $\checkmark$ & \\
\hline Loans to Women & $\checkmark$ & $\checkmark$ & $\checkmark$ & $\checkmark$ & \\
\hline
\end{tabular}

The best practices model dictates exactly how the institutions, regardless of country or region or even village location, must be set up and run with an emphasis on certain factors like repayment and interest loans. When it comes to checking for over indebtedness, only the NGO programs check to make sure that potential clients do not already have outstanding loans at other MFI 
institutions. For offering a variety of financial services, most MFIs qualify for best practices because they provide loans and savings programs. However, this could also include increased access to financial services, through ATMs or more branches. As part of the best practices, most MFIs do not consider client's poverty level when determining loan access, instead they use poverty line measures to determine access. This means that they do not often lend to the very poor. The exceptions to this are the NGOs, which do lend to the very poor as well as the economically active poor.

All MFIs meet the best practice of self-sufficiency because of loaning structures; however, NGOs like Pro Mujer receive a larger portion of their funds from donors. None of the banks under study rely on subsides to function. All of the MFIs measure financial outcomes because best practices has a more narrow focus on loan repayment, therefore the institutions need to measure repayment statistics in order to maintain funding structures. Only a few of the MFIs measure social performance, and this is because best practices does not emphasize social indicators that can impact poverty. The institutions that do deviate from the best practices model measure how social programs are impacting clients. Furthermore, when it comes to government regulation only the commercial banks adhere to this, and that is because they take deposits and have to abide by tax and financial regulation policies of government. Additionally, this is also a recognition of limited government intervention in the sense that they do not have any government funding and as private banks face few governmental restrictions than NGOs. Lastly, when it comes to interest rates, the only bank the deviates from the best practices of capping interest rates is Pro Mujer. As a deviation from the best practices, they use a flat rate that allows them to keep rates low, which is a commitment of the bank to make lending more accessible and affordable. 
The MFIs that follow best practices do not cap their interest rates and therefore can and do charge what they consider market values. This results in much higher interest rates. This is a main focus of best practices because even if the client only pays back a portion of the loan, the bank is still profiting off the loan because of the increased interest. By following best practices, institutions are often unable to meet the local domestic and social realities of the very people they are trying to help. The following section will discuss how the best practices impacts the economic wellbeing of clients in each of the MFI's under study.

\section{Comparing the Economic Impact of Best Practices.}

One of the most important aspects to the underlying ability of microfinance to achieve poverty reduction and development is its ability to divert from best practices. Therefore, best fit organization/structure will be used to highlight the importance of community development schemes for sustainable economic and social development. The bank loan balances and adherence to best practices was used in order to look at the ability of MFIs to divert from the CGAP program and make their own decisions about development programs.

I theorized that the ability of microfinance to reduce poverty is connected to their use of best practices models instead of best fit models. The debt overhang economic theories show that as debt increases repayment and true growth decreases. This is something that is hidden with microfinance. Most microfinance institutions boast a high repayment rate often times in the $95^{\text {th }}$ percentage. However, the data has shown that client's usages of subsequent loans to repay previous loans creates debt cycles creates high levels of debt among MFI clients.

The client's poverty rate of Banco Economico, Compartamos, and Pro Mujer Mexico are high when compared with their adherence to best practices index, banks that follow the best practices models as opposed to the best fit models have higher instances of poverty among 
clients. This is taking into consideration with the average loan balance per borrow. The more the MFI follows best practices; there is an increase in the average amount of money that clients owe the bank. The following table 5.2 shows what the average loan balance per client is for each MFI. ${ }^{303}$

Table 5.2 Average Loan Balance per Clien
\begin{tabular}{|l|c|}
\hline Bank & \\
\hline BancoSol & $\$ 4,190$ \\
\hline Compartamos & $\$ 484$ \\
\hline Banco Economico & $\$ 3,780$ \\
\hline Pro Mujer-Mex & $\$ 349$ \\
\hline Pro Mujer-Bol & $\$ 714$ \\
\hline Idepro & $\$ 3,908$ \\
\hline
\end{tabular}

When looking at this data the connection between the adherence to best practices and the larger loans it can be argued that the more indebted clients are the more likely the MFI has a stricter adherence to best practices which could result in lower levels of poverty reduction. When it comes to Pro Mujer, they have lower loan balances and they also adhere to fewer of the best practices. This is because they track clients across institutions to ensure over lending does not occur. This focus reduces the debt overhang and debt cycles that can have negative impacts on economic development and poverty reduction.

Considering Compartamos, with a higher adherence to the best practices (table 5.1) and a high poverty rate of clients, they have lower levels of loan balance that we see with the NGO versions of microfinance that are more in line with best fit models. There are several explanations for why this may have occurred. First, Compartamos is the only publicly traded MFI in the study and therefore has stricter rules regarding client repayment and loan portfolios to market

${ }^{303}$ Copyright 2020, Microfinance Information Exchange, Inc. https://datacatalog.worldbank.org/dataset/mix- 
manage the risks that are inherent with microfinance loans. Second, they have more clients then the other banks and therefore with higher percentages of clients they have lower loan balances because both new clients who only have one loan are also counted with clients that have been with the MFI for multiple years.

Findings for Economic Hypothesis. A core argument for this dissertation is that microfinance best practices does not allow for sufficient adjustment by the MFI to local political, social, or economic conditions and therefore has a reduced capacity for poverty alleviation. For a best fit model, microfinance institutions need to be flexible and approach development of their communities on the community level of analysis. The best practices laid out by the World Bank, USAID, and IMF requires that institutions follow the eleven principles for continued funding and program survival. A best fit model would design programs for their community as they see fit. The best fit model could include, educational programs, gender violence programs, agricultural or manufacturing programs that are appropriate, as well as healthcare and housing programs that members in impoverished countries need. This approach is best suited toward non-profit MFIs that do not rely on the neoliberal Washington consensus economic model for funding. Best fit is exactly that: a model of development that is the best fit for the community.

Hypothesis 1: Microfinance clients are more likely to have a greater amount of economic wellbeing if the MFI does not adhere to best practices. This focuses on the economic wellbeing of MFI clients in relation to the institutional design of their lender. I have shown that the economic wellbeing of clients is can be positively impacted if the MFI does not adhere to best practices. As supported by the details laid out in my case studies, those clients who belong to MFIs that do not adhere to best practices have lower loan amount, lower debt accumulation, more financial education, more technological support, lower loan balances, and less over 
indebtedness. I found that this hypothesis therefore is confirmed and that a reliance on the clients overall financial wellbeing means that clients are less likely to take out multiple loans and therefore have less debt accumulation.

Comparing the Socio-Cultural Impact of Best Practices. When it comes to poverty alleviation and microfinance, the story is complex because there are many endemic reasons for poverty, and microfinance is just one tool to alleviate it. However, what is most telling about the poverty reduction claims of microfinance is not the potential to do so but the lack of outcomes that occur among reduced poverty rates for clients and communities. The whole story must include other dimensions of poverty reduction though, specifically state involvement. When considering the reduction of poverty it is important to count the social public expenditures of the government. The current best practices model of microfinance is less concerned with social welfare programs and more concerned with loan repayment. Table 5.3 shows where the different MFIs deviates from best practices and adopt extra social programs. The different factors under consideration are separated into three categories: poverty, social capital, and gender equity. 
Table 5.3 Social and Welfare Programs Adopted

\begin{tabular}{|c|c|c|c|c|c|}
\hline & Banco Sol & Compartamos & Banco Economico & Pro Mujer & IDEPRO \\
\hline \multicolumn{6}{|l|}{ Poverty Alleviation Programs } \\
\hline ---------Housing & $\checkmark$ & & & & \\
\hline ------Water and Sanatiation & $\checkmark$ & & & & \\
\hline --------Tracks Food Security & & & & $\checkmark$ & \\
\hline ------Measures Client Poverty & & & $\checkmark$ & & $\checkmark$ \\
\hline \multicolumn{6}{|l|}{ Social Capital Programs } \\
\hline -------Adult Education & $\checkmark$ & & & $\checkmark$ & \\
\hline \multicolumn{6}{|l|}{--------Youth Education } \\
\hline -------Health Insurance & $\checkmark$ & & & $\checkmark$ & \\
\hline -------Schloarships/Education Grants & & & & $\checkmark$ & \\
\hline ------Primary Care & & & & $\checkmark$ & \\
\hline \multicolumn{6}{|l|}{ Gender Equity Programs } \\
\hline -------Domestic Violence Prevention & & & & $\checkmark$ & \\
\hline --------Gender Training & & & & $\checkmark$ & \\
\hline -------Non-Discrimination Policy & $\checkmark$ & $\checkmark$ & $\checkmark$ & $\checkmark$ & \\
\hline --------Leadership Training & & & & $\checkmark$ & \\
\hline
\end{tabular}

When considering poverty alleviation, housing and water or sanitation improvement policies are mainly loan programs to allow for household improvement. Therefore, it is still in line with the general best practices. The outlier is obviously Bolivia's Banco Sol. while they do not deviate strongly from the best practices model they have instituted a few development programs to increase their welfare goals outcomes, including housing and water improvement programs giving them the greatest boost in that category. However, because they do not deviate strong enough their empowerment score is still as low as other banks that adhere to best practices. The only MFI that goes beyond the standard best practices is Pro Mujer in that they track food security issues and offer nutritional education programs. It is through partnerships with other NGOs, that they work to ensure families have proper nutrition. Pro Mujer's deviance from the best practices allows them to branch out into areas that would not necessarily be profitable for the bank and focus on other community level poverty issues. The most consistent finding was with Pro Mujer, who deviates the most from the best practices and has more 
development programs as well. This is because they follow more closely with the community development models of poverty reduction and therefore have greater impacts in those indicators. When considering social capital, education was considered the most important for MFIs. Banco Sol, which adheres to best practices, offers adult education, but Pro Mujer goes beyond offering these training programs and has scholarship/grant programs for education attainment. Additionally, the other difference is on health. Banco Sol does offer health insurance, this is a financial package and therefore still within the guidelines of best practices. Pro Mujer is the only MFI under study to offer primary care services directly to clients.

Of the gender equity programs the most common is a non-discrimination policy, this is expected because each bank loans to women and the policy just includes ensuring women are not discriminated against in the loan evaluation policy. Only Pro Mujer adopts the other gender equity programs of services for domestic violence victims, leadership training, and gender training. This bank deviates the most from best practices and therefore they are able to adopt other gender equity programs.

As theorized, the NGO Pro Mujer, which deviates from the best practices model the most, also offers the most additional women's empowerment services such as gender issues training, leadership training, and domestic violence services. Banco Sol offers few if any additional services. Compartamos has alternated between offering additional program and not offering them, but does offer one more empowerment service than Banco Sol and therefore has a slightly higher empowerment scale score. IDEPRO, which is modeled after Banco Sol in program development, does not offer them. Banco Economico is modeled after Compartamos, and it has switched between offering programs and not offering programs. 
Pro Mujer is the only institution also to offer legal services to victims of domestic violence. The difference between the MFIs is an important indicator as to why this occurs. Banco Sol and Compartamos are banking institutions, and therefore, they focus more on formal banking services. Banco Economico and IDEPRO are both non-banking financial institutions, which means neither take deposits nor offer savings but do practice giving the small loans. Pro Mujer is a non-profit and as such, they have different goals in mind when focusing on microfinance. They do not only consider the provisions of loans and access to financial services as the end all be all of development and have committed themselves to addressing the Millennium Development Goals. By paying attention to a wider degree of development barriers, they are able to design programs that can address more of the factors that go into poverty. For example, Pro Mujer focuses specifically on preventive care because women often do not seek medical care because of family obligations, work obligations, but also because of geographical barriers. By setting up primary care clinics within their loan offices they've increased access and created a "one stop shop" for women's' care.

Furthermore, Pro Mujer, which is allowed to design their programs for their clients, is more likely to develop gender empowerment programs. As such, these development projects shift from a best practices model to what I argue is a best fit model. This means a commitment to building upon existing domestic institutional arrangements. Essentially, for microfinance to be successful it needs to "question the ideological forces, vested interests, and political pressures that promote institutional mimicry" within the microfinance field. ${ }^{304}$ In order to move beyond

\footnotetext{
${ }^{304}$ David Booth., "Governance for Development in Africa: Building on what Works" Africa Power and Politics Policy Brief 1 (April 2011): 1
} 
this mimicry, organizations have to take into account the broader influence from the state, society and redefine socially acceptable economic behavior. ${ }^{305}$

Findings for Socio-Cultural Hypothesis. Armendariz and Morduch (2010) point out that the idea that microfinance has a "clear record of social impact" is a myth. This stems from the different ways in which social impact and social capital can be defined. I propose that part of this myth centers on the institutional design of microfinance, the adherence to best practices and how it limits what policies and programs they adopt. The literature on microfinance and empowerment is not straightforward. Impact assessments of microfinance require adoption of research methodologies capable of isolating specific effects out of a complicated labyrinth of causal and mediating factors. Knowledge of social impact can be helpful in assessing overall program effectiveness. As such, there are two main hypotheses that are addressed in this section both having to do with the socio-cultural impacts and the failure to generate poverty reduction if microfinance follows a best practices modeling. The hypotheses addressed in the key findings:

Hypothesis 2: MFIs are more likely to address issues of patriarchy and domestic violence if they do not adhere to best practices. In my case studies, I have shown that banks that do not adhere to best practices are more likely to provide programs that would work to resolve issues of patriarchy and domestic violence. By not adhering to the best practices model, Pro Mujer clients had far more services provided to them to address gender issues. Additionally, it was the only MFI under study to provide legal services for victims of domestic violence. I found that while limited by the scope of this study focusing on a few MFIs, those institutions that did adhere to best practices had clients that were less likely to have empowerment services. Therefore, I find that this hypothesis is upheld.

\footnotetext{
${ }^{305}$ Christine Oliver., "Sustainable Competitve Advantage: Combining Institutional and Resource Based Views” Strategic Management Journal 18, no. 9 (1997): 697.
} 
The revolution that has become microfinance over the last twenty years has not only focused on the importance of development for the poor, but many programs have specifically targeted women in hopes of empowering them and thereby creating equality. This gender specific targeting, however, does not lead to women using or controlling the loans they are receiving. The microfinance industry has spawned an important political connection between women's empowerment and loans, which has created a social cause for donors and Microfinance Institutions (MFIs) to get behind and continue to fund microfinance programs. However, such MFIs have done little to understand the gender relations of their clients so their programs are not effectively tailored to such issues, which greatly reduce their impact.

\section{Summary and Conclusion}

This chapter has examined what types of programs that MFIs adopt when they follow best practices, and what type of programs they could adopt if they deviated and followed a best fit design. Each of the cases addresses where they follow best practices and where they deviate. Additionally, they show that when MFIs follow best practices there are distortions among economic and socio-cultural factors created. One of the most interesting findings is that among just economic factors banks that follow best practices tended to have higher interest rates, higher levels of client debt, larger loan balances, and more outstanding client balances. This is interesting because one of the reasons best practices was originally thought of was that clients were not being helped out of debt, especially if the bank collapsed. The idea of the creation of best practices was to shore up the MFIs lending practices to protect clients from institutional failure. What this does show is that those institutions that follow best practices have more client debt. This dissertation has also shown that those institutions that follow best practices do not check for over indebtedness. They do not ensure that clients do not have multiple loans at 
multiple institutions. Those institutions that deviate from best practices and adopt a best fit design have client poverty checks to make sure clients are not taking out more money than they could pay back. This is an important indicator of poverty that the best practices model does not account for. Lastly, among the economic factors considered this dissertation has shown that MFIs that follow best practices have higher interest rates. This makes it more difficult for clients to repay the loans and can lead to debt cycles. What this dissertation has shown is that when MFIs follow the best practices model, economic distortions are created.

Furthermore, some of the strongest findings of this dissertation are that when an MFI deviates from best practices and approaches a best fit design they have more social welfare programs. Institutions that approach the best fit model have introduced several social welfare based programs to benefit clients. They have overwhelmingly tried to address other issues that affect poverty. They have introduced educational programs that are not just centered on financial literacy, but also introduced programs to ensure general education as well as scholarship programs for those wishing to attend higher education. Additionally, this dissertation has shown that the MFIs that deviate from best practices have introduced programs directly aimed at helping women in instances of domestic violence. These types of programs are aimed at benefiting the lives of women who participate in microfinance loan programs. Lastly, one of the most interesting findings in this dissertation is that those who approached the best fit design addressed issues of poverty and healthcare. Pro Mujer highlights this finding most directly in that they deviate from the best practices model the most. They not only have additional social welfare programs, but they are the only MFI under study that directly supports primary care making sure women and their families have access to healthcare. What this dissertation has shown is that when MFIs follow the best practices model, socio-cultural distortions are created. Furthermore, 
when MFIs approach a best fit model they adopt programs to deal with those socio-cultural issues that impact poverty.

This dissertation has found that those MFIs that follow best practices have fewer social welfare programs and more problems with increased client debt. What this dissertation cannot assess the effectiveness of the different programs for clients; it does highlight how a deviation from the best practices model can result in a wider array of social welfare programs being adopted. What is done is an analysis of the differences in institutional design between the MFIs. Moreover, it has shown how a best fit design takes more factors that contribute to poverty into account and adopting more social welfare programs, than the best practices model does. 


\section{ChaPTER SiX}

\section{SUMMARY AND CONCLUSIONS}

MFIs mission has a great commitment to poverty alleviation. Therefore, they should not just be banks that are set out to make profits. While that is part of their design through best practices, microfinance and the institutions that practice it have always held a commitment to helping the poor from the bottom up. Therefore, areas that have microfinance institutions are more likely to have additional programs that would help people out of poverty. There are many things that impact poverty levels, but MFIs that deviate from best practices focus more on the community needs. This dissertation has analyzed the differences in institutional design and highlighted how a best fit design takes more factors that contribute to poverty into account by adopting additional social development programs. Additionally, this dissertation has analyzed how the best practices model of microfinance does not take into account the local community in which they operate.

This chapter is composed of three main sections. The first section address the core arguments made in this dissertation. The second section highlights this dissertations contribution to the literature. The third section addresses future research directions that can be taken as showing how studying the best practices model affects clients. At the core of this chapter and the entire dissertation is the argument that best practices hinders poverty alleviation because it does not account for local political, economic, or socio-cultural conditions. In this regard, a best fit model of microfinance would have a larger impact on reducing poverty because it could adopt programs that are tailored to their respective region's needs. The following section will summarize the core arguments made in this dissertation. 


\section{Summary of Core Arguments}

This dissertation aims to address the issues of institutional mimicry and the creation of best practices and how that affects the effectiveness of MFIs to alleviate poverty. Several arguments are made throughout and all addresses how a best fit model of microfinance would be more effective. Overall, this dissertation has argued that the adherence to best practices through neoliberal policies has distorted the impacts that microfinance can have on poverty alleviation. This dissertation has addressed these issues over the many chapters. The introduction highlights the core arguments and direction, and the literature review highlights how other scholars have measured MFI effectiveness and how the best practices and microfinance became the poverty alleviation policy of choice. This is driven by the WTO and IMF and their adherence to neoliberal economic development. The theoretical chapter lays out all the theoretical questions that are asked in this dissertation and highlights the core argument that a best fit model of microfinance is more effective at poverty alleviation than the currently predominated mimicked best practices model. The methodology chapter further highlights this argument by layout the hypotheses generated from these questions as well as how ultimately best practices and poverty alleviation are related. The substantive chapters each have unique findings that show that best practices actually are very good at adopting social programs that can benefit the community, while simultaneously arguing that this is because they do not follow a best fit model. Finally, this dissertation wraps up with a discussion in this chapter about how microfinance's impact has been considered and how this study represents a significant contribution to the literature with a distinctive approach focusing on the institutional components of the MFIs themselves.

At the heart of this dissertation is the argument that neoliberal economic development policy has shaped the microfinance field. This is done by addressing how the microfinance came 
about in the first place and why statist development models were abandoned in favor of neoliberal economic development policies. Additionally, this is addressed by highlighting how the involvement of international institutions impacted microfinance and actually increased the level of mimicry in the field that resulted in the best practices model being the only acceptable model of microfinance. Following this argument, a secondary argument is made that reliance on neoliberal development policies ignores local economic, political, and social realities and actually hinders poverty alleviation efforts. This is because these policies are often adopted with littler regard to what is actually happening in the state, as the microfinance institutions following best practices become more focused on generating income and being profitable and sustainable than they do on helping their clients out of poverty. In this way, this dissertation has argued that following best practices can undercut poverty alleviation efforts. These arguments have led to the core argument presented throughout this dissertation that if microfinance followed a best fit model then poverty reduction indicators could be better.

The sole focus of this dissertation has been to look at the institutional structures of microfinance, and show how these institutions are mimicked through best practices, which in turn hinders poverty alleviation. The secondary main argument has focused on solving that problem by addressing a best fit model of microfinance. It is in this argument as well, that this dissertation contributes to the larger literature on microfinance by presenting an alternative to best practices and arguing that local economic, political, and socio-cultural determinants matter when it comes to constructing an effective model for poverty alleviation. This dissertation focuses on Latin America because this is where microfinance has operated the longest on the best practices model and highlights how development from the bottom up is not occurring while offering an explanation for why - the best practices model. It is important to highlight that there 
is no argument against microfinance as a poverty alleviation tool, but instead it is about the structurer of the policy and institutions that create problems. Microfinance, if it took into account local conditions and generated policies to fit, then it would be able to adopt programs that clients need the most, actually fill in the gaps in the state welfare system that is ineffective, and actually raise poverty levels. It is argued here that, microfinance can be an incredible poverty alleviation tool, when done correctly, and in regards to local conditions.

\section{Contribution to the Literature}

This dissertation adds to the literature on microfinance in two main ways. The first contribution is the complex analysis of the literature combining economic and socio-cultural factors. Second, the theory and methodology of this dissertation is unique in that it looks at the institutional design through best practices and breaks down how the MFIs operate internally while comparing differences across banks. This is an important contribution to the literature because it openly critiques best practices instead of just accepting them as is, and takes this a step further by proposing a solution to the downfalls of best practices through a best fit model that would adapt policies and programs to the local conditions having a greater chance at actual poverty alleviation. This section will discuss each of these impacts, starting with the contribution to the literature analysis.

\section{Complex Analysis of the Literature}

The literature on microfinance tends to be fragmented in that there is a separation between the economic side of microfinance and the social and cultural side of it. Additionally, impact assessment studies tend to focus narrowly on one set of outcomes. This dissertation is unique in the analysis of this literature because an intersectional approach to the analysis is taken. The story of microfinances success is complex and the literature needed to be combined. 
This way economic factors like neoliberal policies and debt cycle with other sociological literature on gender and the impact that social construction has on poverty; furthermore, this dissertation combines these two aspects with policy research adding in another layer of how actual microfinance programs are developed and adopted across the World. Combining all these approaches to the study of microfinance tells the wider story that a policy pushed by neoliberal development paradigms creates dysfunctional institutions, which could limit poverty reduction. This complex overarching view contributes to the field of microfinance study by combining these multiple aspects.

\section{Extending the Theoretical Understanding of Best Practices}

As microfinance begins to move into the mainstream, it is becoming more than an economic policy for growth. Microfinance institutions have been set up to deal with the loans to underserved populations that the traditional banks did not know how to deal with because of the lack of collateral and poverty level. The microfinance institutions have moved into this space to serve these populations, however, as microfinance has become larger so has debate over its impact. This literature adds to the debate through the theoretical foundations of how mimicry impacts microfinances ability to alleviate poverty. Specifically, what is looked at in this dissertation is how the differences in political institutions (in this case the MFIs best practices) impact economic effects (poverty alleviation). Theoretically, this rich study combines a multitude of economic and socio-cultural factors to highlight the impact of microfinance. The greatest contribution here is the theoretical model that underpins microfinances success to their institutional design in best practices. This is crucial to the understanding of how microfinance institutions have generated institutional mimicry in the development politics field. 
Using best practices to highlight how mimicry distorts both economic and socio-cultural conditions, this dissertation has made a strong argument that for better results in poverty alleviate a best fit model is needed. The greatest theoretical contribution of this dissertation is to offer an alternative to the best practices model - the best fit model. This would entail tailoring programs to the local political and social conditions in which the microfinance institutions operate. If microfinance policies were more adaptive, they would have a greater impact on poverty alleviation. This was seen with the inclusion of Pro Mujer in the cases because they deviated from the best practices model and represented a more comprehensive best fit model of microfinance. This dissertation has added significantly to the understanding of microfinance by adding a new model of microfinance and highlighting the ability of the best fit model to be more successful in alleviating poverty.

\section{Future Research Directions}

The changing nature of the political world has led to an increase in the complexities that arise when attempting to study politics. There are several methods through which scholars attempt to answer the "big" questions of politics. The questions are only further compounded by the state of the discipline. There are many different angles from which to approach a question and each researcher is working from different perspective within the field of political science itself. Some of the subfields in political science from which researchers work are policy orientations, international relations, gender studies, political theory, comparative politics, American politics, and sometimes a mixture of any of these fields. As such, the complexity of studying politics arises quickly, and there are just about as many methods to study questions within these fields as there are questions themselves. 
The best direction for future research is to study the impact of best practices on all microfinance institutions throughout Latin America. This would present a further picture how microfinance mimicry has shaped not only the field of microfinance in Latin America but also shaped the direction of development projects in the region. This would undercover some hidden factors of poverty that were beyond the scope of this study by looking at the different political factors that contribute to poverty. The theoretical application of the best fit model to regions outside of Latin America would also contribute significantly to the literature by linking more strongly the correlations between institutional design and poverty alleviation. This would strengthen the arguments that adherence to best practices and institutional design actually negatively affects the ability of the MFI to alleviate poverty by removing exogenous poverty indicator variables and focusing more specifically on institutional design.

The larger overall direction of future research would be to explore more in-depth the links between best practices and poverty alleviation efforts of MFIs. This could be done on a local level with the use of more qualitative survey methodology that asks clients exactly how they use the loans and what level of poverty they experienced before, during, and after their interactions with the microfinance officers and institution. This would specifically focus on clients perceptions of the MFI as well, so that it would be possible to uncover hidden practices at MFIs that would either encourage clients to work their way up the economic ladder and out of poverty but also uncover those indicators that would inhibit such poverty reduction practices.

There will always be future directions when studying microfinance and poverty alleviation. This is an area with a wealth of new inquires. While this represents a positive note, there is also a hazard to oversimplifying the poverty processes that occur. There are multitudes of indicators that can be used in developing poverty reduction schemes, including economic, social, 
and political. With such a wide cross section of possible variables, it is important to refine the questions and methodologies used. One area of future research would be how microfinance following a best fit model could help prevent food insecurity, which is an important indicator of poverty but not one currently addressed. This would highlight how a best fit model could adapt to the local conditions and really introduce poverty reduction programs that their clients need and want.

The major question throughout this dissertation has been whether microfinance institutions hold up their end of the bargain and deliver on poverty alleviation promises. The starting point for this dissertation was with the massive debt failures and bank failures that represented massive microfinance failures in Bolivia in 2000. The questions that resulted from this focused on the failures of microfinance and what causes such failures, however, that is really only part of the story. In order to see failure, it is also necessary to acknowledge growth and success. This is where this dissertation started. It further refined the main questions asked down to really one centralized question does best practices adherence hinder poverty alleviation efforts of MFIs? This is the main question that this dissertation asked in a multitude of ways. The aspects looked at were not only economic but also social and represents the wider gamut of issues in the development studies field. In the end, this dissertation found that institutional design plays a huge part in the ability of MFIs to adopt social welfare programs to help their communities out of poverty. 


\section{BIBLIOGRAPHY}

Aagaard, Peter. 2010. "Institutional Change and the Spheres of Authority: The Case of Microcredit Center for Democratic Network Governance Working Paper (June): 1-34.

Acquaah, Moses. 2008. "Social Capital: The Benefits, Potential Costs, and Prospects" ESR Review 10, no. 2: (Fall): 12-18.

Adams, Dale, and Linda Mayoux. 2001. "Crossfire." Small Enterprise Development 12, no. 1: 46.

Adams, John, and Frank Raymond. 2008. "Did Yunus deserve the Nobel peace prize: Microfinance or macrofarce?." Journal of Economic Issues 42, no. 2: 435-443.

Adler, Emanuel, and Peter Haas. 1992. "Conclusion: Epistemic Communities, World Order, and the Creation of a Reflective Research Program" International Organization 46, no. 1 (Winter): 367-390.

Aggarwal, Gaurav, and M.K. Bhat. 2013. "MIS and Microfinance Issues, Challenges, and Future Prospects." International Journal of Business and Management Invention 2, no. 4 (April): $52-58$.

Ahlin, Christian, Jocelyn Lin, and Michael Maio. 2011. "Where Does Microfinance Flourish? Microfinance Institution Performance in Macroeconomic Context" Journal of Development Economics 96: 105-120.

Ahlin, Christian, and Robert Townsend. 2003. "Using repayment data to test across models of joint liability lending." Working project, Department of Economics, University of Chicago.

Ahmed, Fakhruddin, Brad Brown, Susan Perry Williams. 2013. "Is it time to Regulate Microfinance?" Progress in Development Studies 13, no. 3: 209-220.

Ahmed, Mokbul Morshed. 2003. "Distant Voices: The Views of the Field Workers of NGO in Bangladesh on Microcredit" The Geographical Journal 169, no. 1 (March): 65-74.

Aitken, Rob. 2013. "The Financilaization of Micro-Credit" Development and Change 44, no. 3: 473-499. . 2010. "Ambiguous Incorporations: Microfinance and Global Governmentality" Global Networks 10, no. 2 (March): 223-243. 
Alesina, Alberto. 2000. "Who Gives Foreign Aid to Whom and Why?" Journal of Economic Growth 5 (March): 33-63.

Allison, Graham. 1969. "Conceptual Models and the Cuban Missile Crisis" The American Political Science Review 63, no 3 (September): 689-718.

Alvarez, Sonia. 2009. "Beyond NGO-ization? Reflections from Latin America" Development 52, no. 2: 175-184.

Amin, Ash. 1999. "An Institutalist Perspective on Regional Economic Development" International Journal of Urban and Regional Research 23, no. 2: 365-378.

Angelucci, M, and D.Karlan, and J. Zinman. 2015. "Microcredit impacts: Evidence from a randomized microcredit program placement experiment by Compartamos Banco" American Economic Journal: Applied Economics 7 no. 1: 151-82.

Anderson, C. L., Laura Locker, and Rachel Nugent. 2002. "Microcredit, Social Capital, and Common Pool Resources" World Development 30, no. 1: 95-105.

Andrews, Matt, Lant Pritchett, and Michael Woolcock. 2017. Building State Capability: Evidence, Analysis, Action. Oxford University Press.

Anduanbessa, Tsegaye. 2009. "Statistical Analysis of the Performance of Microfinance Institutions: The Ethiopian Case" Savings and Development 33, no. 2: 183-198.

Armendariz, Beatriz, and Jonathan Morduch. 2010. The Economics of Microfinance. Cambridge Publishing. . 2004. "Microfinance: Where do we Stand?" in C Goodhart, ed. Financial Development and Economic Growth Palgrave: 135-149.

Armendáriz, Beatriz, and Nigiel Roome. 2008. "Gender Empowerment in Microfinance" MPRA Paper No. 31040 (May): 1-25.

Arora, Payal. 2012. "Your Kool-Aid is not my Kool-Aid: Ideologies on Microfinance within and INGO Culture" Development in Practice 22, no. 7: 1006-1018.

Arun, Thankom. 2005. "Regulating for Development: The Case of Microfinance" The Quarterly Review of Economic Finance 45: 346-357. 
Arunachalam, Ramesh S. 2011. The Journey of Indian Micro-Finance: Lessons for the Future. Chennai: Aapti publications.

Augsburg, Britta, and Cyril Fouillet. 2010. “Profit Empowerment: The Microfinance Institution's Mission Drift" Perspectives on Global Development and Technology 9 (June): 327-355.

Avery, Lisa. 2005. "Microcredit Extension in the Wake of Conflict: Rebuilding the Lives and Livelihoods of Women and Children Affected by War" Georgetown Journal on Poverty Law and Policy 12, no. 2 (Summer): 205-240.

Baddeley, Michelle. 2006. "Convergence or Divergence? The Impacts of Globalisation on Growth and Inequality in Less Developed Countries" International Review of Applied Economics 20, no. 3 (July): 391-410.

Bagchi, Amiya Kumar. 1982. The Political Economy of Underdevelopment. Cambridge: University Press.

Bakhtiari, Sadegh. 2006. "Microfinance and Poverty Reduction: Some International Evidence." International Business and Economics Research Journal 5, no. 12 (December): 65-71.

Balkenhol, Bernd, ed. 2007. Microfinance and Public Policy: Outreach, Performance, and Efficiency. New York: Palgrave Macmillian.

Barnes, Carolyn. 2005. "Microcredit and Households Coping with HIV/AIDS: A Case Study from Zimbabwe.” Journal of Microfinance 7, no. 1 (Summer): 55-77.

Barr, Michael S. 2004. "Microfinance and Financial Development” Michigan Journal of International Law 26 (Fall): 271-296.

Barry, Jack. 2012. "Microfinance, the Market and Political Development in the Internet Age." Third World Quarterly 33, no. 1: 125-141.

Basher, Md. Abul. 2012. "Welfare Implication of Foreign Aid and Domestically Funded Microfinance Programs" Review of European Studies 4, no. 1 (March): 235-244. . 2007. "Empowerment of Microcredit Participants and Its Spillover Effects: Evidence from the Grameen Bank of Bangladesh" The Journal of Developing Areas 40, no. 2 (Spring): 173-183. 
Basu, Anupam, Rodolphe Blavy, and Murat Yulek. 2004. "Microfinance in Africa: Experience and Lessons from Selected African Countries" IMF Working Paper WP/04/174 (September): 1-23

Bate, Peter. 2007. "Governments in Microfinance: Threat or Opportunity?" Microenterprise Americas Magazine (Fall): http://www.iadb.org/en/news/webstories/2007-1109/governments-in-microfinance-threat-or-opportunity,4134.html

Bateman, Milford. 2013. "The Age Of Microfinance: Destroying Latin America Economies from the Bottom Up" Osterreichische Forschungsstiftung fur Internationale Entwicklung Working Paper 39 (May): 1-33.

. 2012. "The Role of Microfinance in Contemporary Rural Development Finance Policy and Practice: Imposing Neoliberalism as 'Best Practice"' Journal of Agrarian Change 12, no. 4 (October): 587-600.

. 2012. "Why Doesn't Microfinance Work?: The Destructive Rise of Local Neoliberalism Reviewed" Progress in Development Studies 12, no 1: 83-92.

. 2012. "How Lending to the Poor Began, Grew, and Almost Destroyed a Generation in India" Development and Change 43, no. 6: 1385-1402.

. 2011. Confronting Microfinance: Undermining Sustainable Development. Sterling: Stylus Publishing.

Bateman, Milford, and Ha-Joon Chang. 2012. "Microfinance and the Illusion of Development: From Hubris to Nemesis in Thirty Years." World Economic Review 1: 13-36.

Bateman, Milford, Dean Sinkovic, and Marinko Skare. 2012. “Bosnia’s Microfinance Meltdown.” American Economics Association Annual Conference Chicago. (January): 1-9.

Baumann, Ted. 2004. "Pro-Poor Microcredit in South Africa: Cost-Efficiency and Productivity of South African Pro-Poor Microfinance Institutions" Development Southern Africa 21, no. 5 (December): 785-798.

Bayer, Kurt. 2009. "Neoliberalism and Development Policy - Dogma or Progress?" Development Dialogue 51 (January): 89-102.

Bayulgen, Oksan. 2008. "Muhammad Yunus, Grameen Bank and the Noble Peace Prize: What Political Science Can Contribute to and Learn From the Study of Microcredit" International Studies Review 10: 525-547. 
Becchetti, Leonardo, and Fabio Pisani. 2010. "Microfinance, Subsides, and Local Externalities" Small Business Economics 34: 309-321.

Bedecarrats, Florent, Johan Bastiaensen, and Francois Doligez. 2012. "Co-optation, Cooperation or Competition/ Microfinance and the new left in Bolivia, Ecuador, and Nicaragua." Third World Quarterly 33, no. 1: 143-160.

Bendig, Mirko, Lena Giesbert, and Susan Steiner. 2009. "Savings, Credit and Insurance: Household Demand for Formal Financial Services in Rural Ghana" Working Paper German Institute of Global and Area Studies 94 (January): 1-32.

Bennett, Andrew, and Colin Elman. 2006. "Qualitative Research: Development in Case Study Methods" Annual Review of Political Science 9: 455-476.

Bera, Sayantan. 2008. "Programme Design and Impact Assessments: 'Success' of Microfinance in Perspective" Economic and Political Weekly 43, no. 32 (August): 77-85.

Berg, Marrit van de, Robert Lensink, and Roselia Servin. 2015. "Loan Officers' Gender and Microfinance Repayment Rates.” The Journal of Development Studies 51, no. 9: 1241-1254.

Berger, Allen, Hasan Ifrekhar, and Leora Klapper. 2004. "Further Evidence on the Link between Finance and Growth: An International Analysis of Community Banking and Economic Performance" Journal of Financial Servies Research 25, no. 2 \& 3: 169-202.

Berger, Marguerite, Lara Goldmark, and Tomas Miller Sanabria, eds. 2006. An Inside View of Latin America Microfinance? Washington: Inter-American Development Bank.

Bhatt,Chetan. 2007. "Frontlines and Interstices in the Global War on Terror" Development and Change 38, no. 6: 1073-1093.

Bhatt, Nitin. 1997. "Microenterprise Development and the Entrepreneurial Poor: Including the Excluded?" Public Administration and Development 17, no. 371: 386.

Bhatt, Nitin, and Shui-Yan Tang. 2001. "Delivering Microfinance in Developing Countries: Controversies and Policy Perspectives" Policy Studies Journal 29, no. 3: 319-333. 2001. "Designing Group-Based Microfinance Programs: Some Theoretical and Policy Considerations" International Journal of Public Administration 24, no. 1: 1103-1125.

Bhatt, V.V. 1980. Development Perspectives: Problem, Strategy, and Policies. New York: Pergamon Press. 
Bisen, Arjun, Bronwen Dalton, and Rachel Wilson. 2012. "The Social Construction of the Microfinance Industry: A Comparison of Donor and Recipient Perspectives" Cosmopolitan Civil Societies Journal 4, no. 2: 62-83.

Biswas, Soutik. 2010. "BBC News, Medak, Andhra Padesh, 'India's Microfinance Suicide Epidemic' BBC, updated 16 Dec 2010." Reporter, IB Times Staff. "54 committed suicide in AP due to microfinance debts, says SERP: report." International Business Times 29 (2010).

Bladin, Peter. 2007. “Improving Microfinance through Telecommunications." ESR Review 9, no. 1 (Spring): 14-19.

Bloom, Nicholas, Benn Eifert, Aprajit Mahajan, David McKenzie, and John Roberts. 2013. "Does Management Matter? Evidence from India." The Quarterly Journal of Economics 128, no. 1 (February): 1-51.

Bockman, Johanna. 2012. "The Political Projects of Neoliberalism" Social Anthropology 20, no. 3: $310-317$.

Bogan, Vicki. 2012. "Capital Structure and Sustainability: An Empirical Study of Microfinance Institutions" The Review of Economics and Statistics 94, no. 4 (November): 1045-1058.

Booth, David. 2011. "Governance for Development in Africa: Building on What Works." Africa Power and Politics Policy Brief 1 (April): 1-4.

Brand, Ulrich, and Nicola Sekler. 2009. "Postneoliberalism: Catch-all Word or Valuable Analytical and Political Concept?” Development Dialogue 51 (January): 5-14.

Brau, James, and Gary Woller. 2004. "Microfinance: A Comprehensive Review of the Existing Literature" Journal of Entrepreneurial Finance and Business Ventures 9, no. 1: 1-26.

Brett, John. 2006. "We Sacrifice and Eat Less: The Structural Complexities of Microfinance Participation." Human Organization 65, no. 1: 8-19.

Brie, Michael. 2009. "Ways out of the crisis of neoliberalism." Development Dialogue 51 (January): 15-32.

Brigg, Morgan. 2001. "Empowering NGOs: The Microcredit Movement through Foucault's Notion of Dispositif" Alternatives 26, no. 3 (July/September): 233-259.

Brohman, John. 1995. "Economism and Critical Silences in Development Studies: A Theoretical Critique of Neoliberalism" Third World Quarterly 16, no. 2 (June): 297-318. 
Brugger, Ernst, and Bikram Duggal. 2004. "Microfinance Investment Funds: Looking Ahead" A Paper for the 2004 KFW Financial Sector Development Symposium (November): 1-24.

Buckley, Graeme. 1997. "Microfinance in Africa: Is it Either the Problem or the Solution?" World Development 25, no. 7: 1081-1093.

Buss, Terry F. 2005. "Microcredit in Sub-Saharan Africa: A Symposium.” Journal of Microfinance 7, no. 1 (Summer): 1-11.

Cairney, Paul. 2008. Understanding Public Policy: Theories and Issues. New York: Palgrave Draft Copy.

Campbell, Gregor. 2010. "Microfinancing the Developing World: How Small Loans Empower Local Economies and Catalyse Neoliberalism's Endgame.” Third World Quarterly 31, no. 7: 1081-1090.

Carpio, Maria Abigail. 2004. "The Experience of Financial Institutions in the Delivery of Microcredit in the Philippines" Journal of Microfinance 6, no. 2 (Winter): 113-135.

Carvalho, Soniya, Gillian Perkins, and Howard White. 2002. "Social Funds, Sustainability and Institutional Development Impacts: Findings from an OED Review" Journal of International Development 14, no. 5: 611-625.

Casson, Mark, and Marina D. Guista. 2004. "The Costly Business of Trust" Development Policy Review 22, no. 3: 321-342.

Castles, Frances, ed. 1993. Family of Nations: Patterns of Public Policy in Western Democracies. Brooklyn: Dartmouth Publishing.

Castillo, Alfonso. 1999. "Alternative Microfinance Institutions and Vulnerability" Development in Practice 9, no. 5 (November): 605-610.

Caudill, Steven, Daniel Gropper, and Valentina Hartarska. 2009. "Which Microfinance Institutions are Becoming More Cost Effective with Time? Evidence from a Mixture Model" Journal of Money, Credit and Banking 41, no. 4 (June): 651-672.

Centeno, Miguel, and Joseph Cohen. 2012. "The Arch of Neoliberalism" Annual Review of Sociology 38, no. 3 (April): 17-40.

Center for the Study of Labor and Agriculture (CEDLA). 2020. Accessed: http://www.gloobal.net/iepala/gloobal/fichas/ficha.php?id=2808\&entidad=Agentes\&html=1 
Chamlee-Wright, Emily. 2005. "Fostering Sustainable Complexity in the Microfinance Industry: Which Way Forward?" Economic Affairs 25, no. 2: 5-12.

Chant, Sylvia. 2008. "The 'feminisation of poverty' and the 'feminisation' of anti-poverty programmes: Room for revision?." The Journal of Development Studies 44, no. 2: 165-197.

Chant, Sylvia, and Nikki Craske. 2003. Gender in Latin America. London Latin America Bureau Press.

Charmes, Jacques, and Saskia Wierings. 2003. “Measuring Women's Empowerment: and assessment of the Gender-related development index and the gender empowerment measure" Journal of Human Development 4, no 3: 419-435.

Christen, Robert Peck. 2000. "Commercialization and Mission Drift: The Transformation of Microfinance in Latin America” CGAP Occasional Paper no. 5 Washington DC (January): $1-24$.

Christen, Robert, and Deborah Drake. 2001. "Commercialization of Microfinance" Working Paper for US Agency for International Development, Bureau for Global Programs, Center for Economic Growth and Agricultural Development (October): 1-23.

Chowdhury, Jamil. 2000. "Reintegration of Internally Displaced People (IDPs): The Need for Micro Credit” Refugee Survey Quarterly 19, no. 2: 201-215.

Chowdhury, Mushtaque, Paul Mosley, and Anton Simanowitz. 2004. "The Social Impact of Microfinance” Journal of International Development 16: 291-300

Cohen, Monique. 2002. "Making Microfinance More Client Led" Journal of International Development 14, no. 3: 335-350.

Cole, Shawn. 2009. "Fixing Market Failures or Fixing Elections? Agricultural Credit in India" American Economic Journal of Applied Economics 1, no. 1 (January): 219-250.

Coleman, Brett. 1999. "The Impact of Group Lending in Northeast Thailand" Journal of Development Economics 60, no. 1 (October): 105-141.

Coleman, Isobel. 2005. "Defending Microfinance" The Fletcher Forum of World Affairs 29, no. 1 (Winter): 181-189.

Collier, David. 1993. "The Comparative Method" in Finifter (ed) Political Science: The State of the Discipline II. American Political Science Association: 105-119. 
Compartamos Quotes from https://www.facebook.com/CompartamosBanco/ in reply to Compartamos' offer to rework loans for women who could not pay.

Constantinou, Dinos, and Arvind Ashta. 2011. "Financial Crisis: Lessons from Microfinance" Strategic Change 20: 187-203.

Cooley, Alexander, and James Ron. 2002. "The NGO Scramble: Organizational Insecurity and the Political Economy of Transnational Action" International Security 27, no 1 (Summer): $5-39$.

Copestake, J., P. Dawson, J. P. Fanning, A. Mckay, and K. Wright-Revolledo. 2005.

"Monitoring the Diversity of the Poverty Outreach and Impact of Microfinance: A Comparision of Methods Using Data From Peru" Development Policy Review 23, no. 6: 703-723.

Copestake, James. 2007. “Mission Drift - Understand It. Avoid It.” ESR Review 9, no. 2 (Fall): 20-25. . 2002. "Integrating Impact Monitoring and Assessment of Microfinance" Development in Practice 10, no. 5 (November): 705-711.

Coyne, Christopher. 2005. "The Institutional Prerequisites for Post-Conflict Reconstruction" The Review of Austrian Economics 18, no. 3/4: 325-342.

Crabb, Peter. 2004. "Foreign Exchange Risk Management Practices of Microfinance Institutions." Journal of Microfinance 6, no. 2 (Winter): 51-63.

Cull, Robert, Asli Demirguc-Kunt, and Jonathan Morduch. 2008. "Microfinance Meets the Market” World Bank Policy Research Working Paper 4630 (May): 1-40. . 2009. "Does Regulatory Supervision Curtail Microfinance Profitability and Outreach?" Policy Research Working Paper 4748 World Bank Development Research Group Finance and Private Sector Team (June): 1-41. . 2007. "Financial Performance and Outreach: A Global Analysis of Leading Microbanks" The Economic Journal 117 (February): F107-F133.

Cunningham, Shawn, and Jorg Meyer-Stamer. 2005. "Planning or Doing Local Economic Development? Problems with the Orthodox Approach to LED” Africa Insight 35, no. 4 (December): 4-14. 
Daley-Harris, Sam, and Lisa Laegreid. 2006. "State of the Microcredit Summit Campaign: Report 2006.” Microcredit Summit Campaign (Washington, DC): 1-70.

Daniels, Reza. 2004. "Financial Intermediation, Regulation and the Formal Microcredit Sector in South Africa" Development Southern Africa 21, no. 5 (December): 831-849.

Datta, Dipankar. 2004. "Microcredit in Rural Bangladesh: Is it Reaching the Poorest?" Journal of Microfinance 6, no. 1 (Summer): 55-81.

Davids T, Driel F van. 2005. The Gender Question in Globalization: Changing Perspectives and Practice. Ashgate, Aldershot.

Davis, Peter. 2001. "Rethinking the Welfare Regime Approach" SAGE 1, no. 1: 79-107.

Desai, Sameeksha. 2007. "Post-conflict Microfinance: Assessment and Policy Notes for Iraq" Jena Economic Research Papers 60 (September): 1-12.

Dichter, Thomas. 2007. "A Second Look at Microfinance: The Sequence of Growth and Credit in Economic History" CATO Institute 1 (February): 1-15.

Dicken, Peter. Global Shift: Mapping the Changing Contours of the World Economy. New York: Guilford Press, 2007.

Dicklitch, Susan, and Doreen Lwanga. 2003. "The Politics of Being Non-Political: Human Rights Organizations and the Creation of a Positive Human Rights Culture in Uganda" Human Rights Quarterly 25: 482-509.

Dinc, Serdar. 2005. "Politicians and Banks: Political Influences on Government-Owned Banks in Emerging Markets" Journal of Financial Economics 77: 453-479.

Doocy, Shannon, Dan Nrell, Shimeles Teffera, and Gilbert Burnham. 2005. "Outcomes of an Ethiopian Microfinance Program and Management Actions to Improve Services" Journal of Microfinance 7, no. 1 (Summer): 79-94.

Dowla, Asif Ud. 2004. "Microleasing: The Grameen Bank Experience." Journal of Microfinance 6, no. 2 (Winter): 137-160.

Dowla, Asif, and Dewan Alamgir. 2003. "From Microcredit to Microfinance: Evolution of Savings Products by MFIs in Bangladesh" Journal of International Development 15: 969988. 
Duncan, Alex. 1986. "Aid Effectiveness in Raising Adaptive Capacity in the Low-Income Countries" in Lewis and Kallab, eds. Development Strategies Reconsidered. Transaction Books.

Duncan, Ron, and Satish Chand. 2002. "The Economics of the 'Arc of Instability' Asian-Pacific Economic Literature 16, no. 1: 1-9.

Dunford, Christopher. 2000. "In Search of Sound Practices for Microfinance." Journal of Microfinance ESR Review 2, no. 1: 6-12.

Duvendack, Maren, and Richard Palmer-Jones. 2011. "High Noon for Microfinance Impact Evaluations: Re-Investigating the Evidence from Bangladesh." Munich Personal RePEc Working Paper no 27902 (January): 1-42.

Duvendack, M., R. Palmer-Jones, J. Copestake, L. Hooper,Y. Loke and N. Rao, 2011. What is the Evidence of the Impact of Microfinance in the Well-Being of Poor People? Social Science Research Unit EPPI-Centre, University of London.

Elahi, Khandakar Q., and Constantine P. Danopoulos. 2004. "Microfinance and Third World Development: A Critical Analysis" Journal of Political and Military Sociology 32, no. 1 (Summer): 61-77.

Elahi, Khandakar Q., and M. L. Rahman. 2006. "Microcredit and Microfinance: Functional and Conceptual Differences" Development in Practice 16, no. 5 (August): 476-483.

Ellerman, David. 2007. "Microfinance: Some Conceptual and Methodological Problems" in Thomas Dichter and Malcolm Harper, eds. What's Wrong with Microfinance? London: Practical Action Publishers: 149-163.

Ellsberg, M.C., R. Pena, A. Herrera, J. Liljestrand, and A Winkvist. 1999. "Wife abuse among women of childbearing age in Nicaragua" American Journal of Public Health 89, no. 2 (February): 241-244.

Engel, Susan. 2011. "From Theory to Practice in Development" in G.Argyrous and F. Stilwell, eds. Readings in Political Economy: Economics as a Social Science, 3 ed. Tilde University Press: 240-244.

Engler, Mark. 2009. "From Microcredit to a World Without Profit?: Muhammad Yunus Wrestles with Moving Beyond a Society Based on Greed." Dissent 56, no. 4: 81-87. 
Estes, Richard. 1993. "Toward Sustainable Development: From Theory to Praxis" Social Development Issues 15, no. 3: 1-29.

Evans, Timothy, Alayne Adams, Rafi Mohammed, and Alison Norris. 1999. "Demystifying Nonparticipation in Microcredit: A Population-Based Analysis" World Development 27, no. 2: 419-430.

Eversole, Robyn. 2003. "Help, Risk and Deceit: Microenterpreneurs talk about Microfinance" Journal of International Development 15: 179-188.

Eyiah, Alex. 2001. "An Integrated Approach to Financing Small Contractors in Developing Countries: A Conceptual Model" Construction Management and Economics 19: 511-518.

Faccio, Mara, Ronald Masulis, and John McConnell. 2006. "Political Connections and Corporate Bailouts" The Journal of Finance 61, no. 6 (December): 2597-2635.

Fairbourne, Jason S. 2006. "Microfranchising: A New Tool for Creating Economic SelfReliance" ESR Review 8, no. 1 (Summer): 18-23.

Fairley, Joanne. 1998. "New Strategies for Microenterprise Development: Innovation, Integration, and the Trickle Up Approach" Journal of International Affairs 52, no. 1 (Fall): 339-350.

Fernandez, Aloysius. 2007. "A Microfinance Institution with a Difference" Economic and Political Weekly 42, no. 13 (March-April): 1185-1189.

Fernando, Jude. 2006. Microfinance: Perils and Prospects. New York, Routledge Publishing,

Ferraro, Vincent. 2008. "Dependency Theory: An Introduction," in Giorgio, ed. The Development Economics Reader $2^{\text {nd }}$ edition (London: Routledge): pp. 58-64

Filho, Alfredo Saad. 2010. "Neoliberalism, Democracy, and Development Policy in Brazil" Development and Society 39, no. 1 (June): 1-28.

Finnemore, H. 1996. National Interests in International Society. Ithaca, Cornell Publishing.

Firpo, Janine. 2007. “Banking the Unbanked.” ESR Review 9, no. 1 (Spring): 4-9.

Flake, Ballan, and Renata Forst. 2006. "Fighting Families: Characteristics Associated with Domestic Violence in Five Latin America Countries" Journal of Family Violence 21, no. 1 (January), 19-22. 
Flynn, Patrice. 2007. "Microfinance: The Newest Financial Technology of the Washington Consensus" Challenge 50, no. 2 (March/April): 110-121.

Frank, Andre Gunder. 1969. Latin America: Underdevelopment or Revolution. New York, Monthly Review Publishing.

Frawly, Dylan Kevin. 2019. "Establishing an Effective Interest Rate in Latin America's Microfinance Sector: A Comparative Analysis Between Mexico and Peru" Bard College Digital Commons (Spring): 1-53.

Fukuyama, Francis. 2002. "Social Capital and Development: The Coming Agenda" School of Advanced International Studies Review 22, no. 1 (Winter/Spring): 23-37.

Gago, Veronica, and Diego Sztulwark. 2009. "Notes on Postneoliberalism in Argentina." Development Dialogue 51 (January): 181-192.

Galak, Jeff, Debrorah Samll, and Andrew Stephen. 2011. "Microfinance Decision Making: A Field Study of Prosocial Lending” Journal of Marketing Research 48: S130-S137.

Gardner, Gary. 2002. "Rio + 10 Sustainable Development Revisited" The International Journal of Technology Management and Sustainable Development 1, no. 2: 66-86.

Garmaise, Mark, and Gabriel Natividad. 2013. "Cheap Credit, Lending Operations, and International Politics: The Case of Global Microfinance” The Journal of Finance 68, no. 4 (July-August): 1551-1576.

. 2010. "Information, the Cost of Credit, and Operational Efficiency: AN Empirical Study of Microfinance" Review of Financial Studies 23, no. 6: 2560-2590.

Geoghegan, Martin, and Fred Powell. 2009. "Community Development and the Contested Politics of the Late Modern Agora: of, alongside or against neoliberalism?" Community Development Journal 44, no. 4 (October): 430-447.

George, Alexander, and Andrew Bennet. 2005. Case Studies and Theory Development in the Social Sciences. MIT Press.

Ghate, Prabhu. 2007. "Consumer Protection in Indian Microfinance Lessons from Andhra Pradesh and the Microfinance Bill” Economic and Political Weekly 42, no 13 (MarchApril): 1176-1184. 
Gine, Xavier, Pamela Jakiela, Dean Karlan, and Jonathan Morduch. 2010. "Microfinance Games" American Economic Journal: Applied Economics 2, no. 3 (July): 60-95.

Gingrich, Chris. 2004. "Community-Based Savings and Credit Cooperatives in Nepal: A sustainable Means for Microfinance Delivery?" Journal of Microfinance 6, no. 1 (Summer): 21-39.

Gobezie, Getaneh. 2008. "Success in Expanding Microfinance Opportunities in Rural Ethiopia Can the Entrepreneurship Challenge be Overcome?" African Review of Money Finance and Banking: 117-131.

Goldsworthy, Heather. 2010. "Microfinance, Human Security, and Millennium Development Goal No. 7." Perspectives on Global Development and Technology 9: 449-472.

Gonzalez, Adrian. 2007. "Resilience of Microfinance Institutions to National Macroeconomic Events: An Econometric Analysis of MFI asset quality” MPRA Working Paper 4317 (August): 1-26.

Gonzalez-Vega, Claudio. 1998. "Microfinance Apex Mechanisms: Review of the Evidence and Policy Recommendations” CGAP-OSU Research Project (August): 1-77.

Guler, Isin., Mauro Guillen, and John Muir Macpherson. 2002. "Global competition, Institutions, and the Diffusion of Organizational Practices: The International Spread of ISO 9000 Quality Certificates." Administrative Science Quarterly 47, no. 2 (June): 207-232.

Graham, Scott, Julia Erickson, and Eugene Ericksen. 2014."Over-Indebtedness in Mexico: Its Effects on Borrowers” Microfinance CEO Working Group. Accessed July 2020: https://www.finca.org/files/2014/05/Over-Indebtedness-in-Mexico-Its-Effect-onBorrowers.pdf

Greeley, M. 1996. "Poverty and Well Being: Problems for Poverty Reduction in the Role of Credit" In Who Needs Credit? Poverty Finance in Bangladesh, Wood G., Sharif I. (eds.). Dhaka: University Press, 83-96.

Gruening, Hennie van, Joselito Gallardo, and Bikki Randhawa. 1998. "A Framework for Regulating Microfinance Institutions” Financial Sector Development Department, The World Bank (December): 1-41.

Grugel, Jean, Pia Riggirozzi, and Ben Thirkell-White. "Beyond the Washington Consensus? Asia and Latin America in search of more autonomous development." International Affairs 84, no. 3 (2008): 499-517. 
Griffith-Jones, Stephany, and Jenny Kimmis. 2003. "International Financial Volatility” Journal of Human Development 4, no. 2 (July): 209-225.

Gutierrez-Nieto, B., C. Serrano-Cinca, and C. Mar Molinero. 2009. "Social Efficiency in Microfinance Programs" The Journal of the Operational Research Society 60, no. 1 (January): 104-119.

Haas, Ernst. 1964. Beyond the Nation State. Stanford, University Press.

Haas, Dwight. 2007. “Closing the Gender Gap” ESR 9, no. 2 (Fall): 4-9.

Hass, Mark, 2005. The Ideological Origins of Great Power Politics, 1789-1989. Ithaca: Cornell University Press.

Haas, Peter. 1989. "Do Regimes Matter? Epistemic Communities and Mediterranean Pollution Control" International Organization 43, no. 3 (Summer): 377-403.

Haile, Fiseha, and Miguel Nino-Zarazua. 2018. "Does Social Spending Improve Welfare in Low Income and Mid Income Countries?" in Journal of International Development 30: 367-369

Hall, Richard. 2013. '“What did I do wrong?': Why the banker who helped millions of Bangladeshis out of poverty became his country's enemy number one" The Independent (October 27). Accessed: https://www.independent.co.uk/news/world/asia/what-did-i-dowrong-why-the-banker-who-helped-millions-of-bangladeshis-out-of-poverty-became-his8899838.html.

Hamre, John. J., and Gordon R. Sullivan. 2002. "Toward Postconflict Reconstruction" The Washington Quarterly 25, no. 4 (Autumn): 85-96.

Hardy, Daniel, Paul Holden, and Vassili Prokopenko. 2003. "Microfinance Institutions and Public Policy" Policy Reform 6, no. 3 (September): 147-158.

Harper, Malcolm. 2003. Practical Microfinance: A Training Manual. London: ITDG Publishing.

Harrington, Bill. 2006. "The Changing Role of Foreign Direct Investment in Microfinance Capital and Measurement of Financial and Social Performance" Mennonite Economic Development Associates: 1-27.

Hartarska, Valentia, and Roy Mersland. 2012. "Which Governance Mechanisms Promote Efficiency in Reaching Poor Clients? Evidence from Rated Microfinance Institutions" European Financial Management 18, no. 2: 218-239. 
Hartarska, Valentina, and Denis Nadolnyak. 2007. "Do Regulated Microfinance Institutions Achieve Better Sustainability and Outreach? Cross-Country Evidence" Applied Economics 39: 1207-1222.

Haque, Muhammad Enamul, and Nahid Fatema. 2012. "The Role of the Palli Karma Sahayak Foundation in the Development of Microfinance in Bangladesh" ASA University Review 6, no. 1 (January-June): 285-294.

Haynes, C. B. 2003. "Stable, Sustainable Microfinance" School of Advanced International Studies Review 23, no. 1 (Winter/Spring): 291-296.

Healey, et al. "Institutional capacity-building, urban planning and urban regeneration projects" Futura 18, no. 3 (1999): 117-137.

Heise, Lori. 1998. "Violence Against Women” Violence against Women 4, no 3 (June), 262-290.

Hermes, Niels, and Robert Lensink. 2011. "Microfinance: Its Impact, Outreach, and Sustainability" World Development 39, no. 6: 875-881.

_ 2007. "The Empirics of Microfinance: What Do We Know?" The Economic Journal 117, no. 517 (February): F1-F10. . 2007. "Impact of Microfinance: A Critical Survey" Economic and Political Weekly 42, no. 6 (February): 462-465.

Hickey, Sam. 2012. "Turning Governance Thinking Upside-down? Insights from 'the politics of what works"" Third World Quarterly 33, no. 7: 1231-1247.

Hietalahti, Johanna, and Mikael Linden. 2006. "Socio-Economic Impacts of Microfinance and Repayment Performance: A Case Study of the Small Enterprise Foundation, South Africa" Progress in Development Studies 6, no. 3: 201-210.

Hira, Anil. 2007. "Did ISI fail and is neoliberalism the answer for Latin America? Re-assessing common wisdom regarding economic policies in the region." Brazilian Journal of Political Economy 27, no. 3: 345-356.

Hirst, Paul. 1997. "The Global Economy-Myths and Realities" International Affairs 73, no. 3 (July): 409-425.

Hofstetter, Shana. 2007. "The Interaction of Customary Law and Microfinance: A Women's Entry into the World Economy" Wm. \& Mary J. Women \& L. 14, no. 2 (February): 337-361. 
Hollis, Aldan, and Arthur Sweetman. 1998. "Microcredit: What Can We Learn from the Past?" World Development 26, no. 10: 1875-1891.

Hoque, Mohammad Ziaul. 2004. "Stagnated Growth of Microenterprises and Flawed role of Credit NGOs: Evidence from Bangladesh” Humanomics 20, no. 1/2: 32-39.

Horton, Lynn. 2017. Women and Microfinance in the Global South: Empowerment and Diempowerment Outcomes. Cambridge University Press.

Huber, Evelyne, and Fred Solt. 2004. "Successes and Failures of Neoliberalism” Latin American Research Review 39, no. 3: 150-164.

Hubka, Ashley, and Rida Zaidi. 2005. "Impact of Government Regulation on Microfinance" Prepared for the World Development Report: 1-25.

Hulme, David. 2000. "Is Microdebt good for poor people? A note on the dark side of Microfinance" Small Enterprise Development Studies 11, no. 1 (March): 26-28.

. Hulme, David. 2000. "Impact Assessment Methodologies For Microfinance: Theory, Experience and Better Practice” World Development 28: 79-98.

Hulme, David, and Paul Mosley. 1996. Finance Against Poverty v. 2. New York, Rutledge Publishing.

Hunt, Juliet, and Nalini Kasynathan. 2001. "Pathways to empowerment? Reflections on microfinance and transformation in gender relations in South Asia." Gender \& Development 9, no. $1: 42-52$.

IDEPRO. 2018. “IDEPRO Case Study Report” Global Partnerships Accessed: https://globalpartnerships.org/wp-content/uploads/bsk-pdf-manager/2018/04/GP-IdeproCase-Study-Report.pdf

.2011. "IDEPRO: Bridging the Financial Divide to Reach Small Farmers" Inter American Development Bank. This work is licensed under a Creative Commons IGO. Accessed:https://www.google.com/url?sa=t\&rct=j\&q=\&esrc=s\&source=web\&cd=\&cad=rja \&uact=8\&ved=2ahUKEwiFx5C4vaLqAhWBmHIEHT1QAg4QFjAAegQIBhAB\&url=https $\% 3 \mathrm{~A} \% 2 \mathrm{~F} \% 2 \mathrm{Fpublications.iadb.org} \% 2 \mathrm{Fen} \% 2 \mathrm{Fpublication} \% 2 \mathrm{~F} 16983 \% 2$ Fidepro-bridgingfinancial-divide-reach-small-farmers\&usg=AOvVaw0A0_cxhCVpYfx16MkS0q9I

Ingoldsby, B.B. 1991. "The Latin American Family: Familism vs. Machismo" Journal of Comparative Family Studies 22, no. : 57-62. 
Ito, Sanae. 2003. "Microfinance and Social Capital: Does Social Capital Help Create Good Practice?" Development in Practice 21, no. 1 (August): 61-69.

Jacobsen, Karen, Anatasia Marshak, Akua Ofori-Adjei, and Jane Kembabazi. 2006. "Using Microenterprise Interventions to Support the Livelihoods of Forcibly Displaced People: The Impact of a Microcredit Program in IDP Camps in Lira, Northern Uganda" Refugee Survey Quarterly 25, no. 2: 23-39.

Jacobsen, Karen. 2002. "Livelihoods in Conflict: The Pursuit of Livelihoods by Refugees and the Impact on the Human Security of Host Communities" International Migration 40, no. 5: 95123.

Jaffee, David. 1990. Levels of Socio-Economic Development Theory. New York, Praeger Publishing.

Jeppesen, Soeren. 2005. "Enhancing Competitiveness and Securing Equitable Development: Can Small, Micro, and Medium Sized Enterprises (SME's) Do the Trick?" Development in Practice 15, no. 3 \& 4 (June): 463-474.

Jobim, Maria Luiza Kurban. 2012. "The Real Relation between Microcredit and Development: A Critical Analysis of the International Regulation of Financial Services" Economic Analysis of Law Review 3, no. 1 (January-June): 1-19.

Johnson, Susan. 2005. "Gender Relations, Empowerment and Microcredit: Moving on from a Lost Decade" The European Journal of Development Research 17, no. 2 (June): 224-248. . 2000. "Gender Impact Assessment in Microfinance and Microenterprise: Why and How" Development in Practice 10, no. 1 (February): 89-93. . 1999. "Evaluation of Microfinance Projects" Development in Practice 9, no. 4 (August): 488-490. . 1998. "Microfinance North and South: Contrasting Current Debates" Journal of International Development 10: 799-809.

Jupp, Dee, Sohel Ibn Ali, and Carlos Barahona. 2010. Measuring Empowerment? Ask Them: Quantifying Qualitative Outcomes from People's Own Analysis Insights for Results-Based Management from the Experience of a Social Movement in Bangladesh. SIDA Publishing.

Kabeer, Naila. 2001. "Conflicts Over Credit: Re-Evaluating the Empowerment Potential of Loans to Women in Rural Bangladesh” World Development 29, no. 1: 63-84. 
Kaboski, Joseph, and Robert Townsend. 2011. "A Structural Evaluation of a Large-scale QuasiExperimental Microfinance Initiative” Econometrica 79, no. 5 (September): 1357-1406. . 2005. "Policies and Impact: An Analysis of Village-Level Microfinance Institutions" Journal of European Economic Association 3, no. 1 (March): 1-50.

Kabra, Parikshit. 2011. "Indian Microfinance Crisis.” Opticon 1826, no. 11 (Autumn): 1-3.

Kah, Jainaba M.L., Dana L. Olds, and Muhammadou M.O. Kah. 2005. "Microcredit, Social Capital, and Politics: The Case of a Small Rural Town - Gossas, Senegal." Journal of Microfinance 7, no. 1 (Summer): 119-149.

Kalpana, K. 2005. "Shifting Trajectories in Microfinance Discourse" Economic and Political Weekly 40, no. 51 (December): 5400-5409.

Karlen, Dean. 2001. "Microfinance Impact Assessments: The Perils of Using New Members as a Control Group" Journal of Microfinance 3: 75-85.

Karlen, Dean, and Jonathan Zinman. 2008. "Credit Elasticities in Less-Developed Economies: Implications for Microfinance” The American Economic Review 98, no. 3 (June): 10401068.

Karmaker, K.G. 2009. "Emerging Trends in Microfinance" Economic and Political Weekly 44, no. 13 (March-April): 21-24.

Katzenstein, Peter. 1977. "Introduction: Domestic and International Forces and Strategies of Foreign Economic Policy” International Organization 31, no 4. (Autumn): 587-606.

Kaushal, K.K., and J.C. Kala. 2005. "Nurturing Joint Forest Management Through Microfinance: A Case from India." Journal of Microfinance 7, no. 2 (Winter): 1-12.

Keck, Margaret, and Kathryn Sikkink. 1998. Activists Beyond Borders. Ithaca, Cornell University Press. . 2002. "Transnational Advocacy Networks in International and Regional Politics" International Social Science Journal 51, no 159 (December): 89-101.

Keiner, Marco, ed. 2006. The Future of Sustainability. Netherlands: Springer Publishing. 
Kent, Derin, and M. Tina Dacin. 2013. "Bankers at the Gate: Microfinance and the High Cost of Borrowed Logics." Journal of Business Venturing 28: 1-16 online http://dx.doi.org/10.1016/j.jbusvent.2013.03.002

Kerlin, Janelle. 2013. "Defining Social Enterprise Across Different Contexts: A Conceptual Framework Based on Institutional Factors." Nonprofit and Voluntary Sector Quarterly 42, no. 1: 84-108.

Khalily, M.A. Baqui. 2004. "Quantitative Approach to Impact Analysis of Microfinance Programmes in Bangladesh - What Have We Learned?" Journal of International Development 16; 331-353.

Khan, Mahmuda Rahman. 1999. "Microfinance, Wage Employment and Housework: A Gender Analysis" Development in Practice 9, no. 4 (August): 424-436.

Khandelwal, Anil. 2007. "Microfinance Development Strategy for India" Economic and Political Weekly 42, no. 13 (March-April): 1127-1135.

Khandker, Shahidur. 2005. "Microfinance and Poverty: Evidence Using Panel Data from Bangladesh” The World Bank Economic Review 19, no. 2: 263-286.

Khwaja, Asim Ijaz, and Atif Milan. 2005. "Do Lenders Favor Politically Connected Firms? Rent Provision in an Emerging Financial Market" Quarterly Journal of Economics 120, no. 4: 1371-1411.

Kim, Julia C., et. al. 2007. "Understanding the Impact of a Microfinance-Based Intervention on Women's Empowerment and the Reduction of Intimate Partner Violence in South Africa" American Journal of Public Health 97, no. 10 (October): 1794-1801.

Kinzer, N.S. 1973. "Priests, Machos and Babies: of, Latin American Women and the Manichaean Heresy" Journal of Marriage and Family 35: 300-311.

Kirkpatrick, Colin, and Christopher Green. 2002. "Policy Arena: Finance and Development: An Overview of the Issues" Journal of International Development 14: 207-209.

Kirkpatrick, Colin, and Samuel M. Maimbo. 2002. "The Implications of the Evolving Microfinance Agenda for Regulatory and Supervisory Policy" Development Policy Review 20, no. 3: 293-304.

Kirton, John. 2005. "From Collective Security to Concert: The UN, G8, and Global Security Governance" Paper Presented at Conference on Security Overspill: Between Economic 
Integration and Social Exclusion, Centre Etudes Internationales et Mondialisation, Univeristy of Quebec, Montreal, October 27-28.

Kishor, Ratna N. 2013. "Micro Insurance in India-Protecting the Poor." Journal of business management and Social Sciences Research 2, no. 3 (March): 39-44.

Kostov Zoran. 2005. "From NGOs to FFIs in Microfinance Services: Conversion Road Map and Its Challenges" International Policy Fellowships: 1:41.

Kousis, Maria, and Charles Tilly, eds. 2005. Economic and Political Contention in Comparative Perspective. Boulder: Paradigm Publishers.

Kusago, Takayoshi. 2005. "Post-Conflict Pro-Poor Private-Sector Development: The Case of Timor-Leste" Development in Practice 15, no. 3 \& 4 (June): 502-513.

Lal, Rajiv, and Annelena Lobb. 2016. "BancoSol and Microfinance in Bolivia." Harvard Business School Case 5165 (February): 1-34.

Lapenu, Cecile. 2000. "The Role of the State in Promoting Microfinance Institutions" FCND Discussion Paper no. 89 (June): 1-55.

Lapenu, Cecile, and Manfred Zeller. 2002. "Distribution, Growth, and Performance of the Microfinance Institutions in Africa, Asia, and Latin America: A Recent Inventory" Savings and Development 26, no 1: 87-111.

Lashley, Jonathan. 2004. "Microfinance and Poverty Alleviation in the Caribbean: A Strategic Overview." Journal of Microfinance 6, no. 1 (Summer): 83-94.

Leach, Fiona, and Shashikala Sitaram. 2002. “Microfinance and Women's Empowerment: A Lesson from India” Development in Practice 12, no. 5 (November): 575-588.

Ledgerwood, Joanna, Julie Earne, and Candace Nelson, eds. 2013. The New Microfinance Handbook: A Financial Market System Perspective. Washington: International bank for Reconstruction and Development/The World Bank.

Littlefield, Elizabeth, Jonathan Murduch, and Syed Hashemi. 2003. "Is Microfinance an Effective Strategy to Reach the Millennium Development Goals?" Focus Note 24 (January): $1-12$.

Lityinoff, Miles, and Angele Vermeulen. 2013. “OIKOCREDIT Annual Report 2013: Developing Sustainable Agricultural” Drukkerj Atlas Publishing (Netherlands). 1-71. 
Lont, Hotze, and Otto Hospes. 2004. Livelihood and Microfinance: Anthropological and Sociological Perspectives on Savings and Debt. Netherlands: Eburon Academic Publishers.

Looney, Robert. 2005. "Postwar Iraq's Financial System: Building From Scratch" Middle East Policy 12, no. 1 (Spring): 134-148.

Lucarelli, Bill. 2005. "Microcredit: A Cautionary Tale" Journal of Contemporary Asia 35, no. 1: 78-86.

Ly, Pierre, and Geri Mason. 2012. "Individual Preferences over Development Projects: Evidence from Microlending on Kiva" International Society for Third-Sector Research 23: 10361055.

Macias-Gonzales, Victor and Anne Rubenstein. 2012. Masculinity and Sexuality in Modern Mexico. Albuquerque. University of New Mexico Press.

MacLeavy, Julie. 2012. "The Lore of the Jungle: Neoliberalism and Statecraft in the GlobalLocal Disorder (revisiting Peck and Tickell)" AREA 44, no. 2 (February): 250-253.

Mader, Philip. 2013. "The Rise and Fall of Microfinance in India: The Andhra Pradesh Crisis in Perspective" Strategic Change 22: 47-66. . 2011. "Attempting the Production of Public Goods Through Microfinance: The Case of Water and Sanitation" Presented at the University of Pula $5^{\text {th }}$ International Scientific Conference 'Entrepreneurship and Macroeconomic Management: Reflection on the World in Turmoil' Croatia: 1-19.

. 2011. "Making the Poor Pay for Public Goods via Microfinance: Economic and Political Pitfalls in the Case of Water and Sanitation" Max-Planck Institute for the Study of Societies discussion paper Cologne (November): 1-43.

Maes, Jan, and Malika Basu. 2005. "Building Economic Self-Reliance: Trickle Up's Microenterprise Seed Capital for the Extreme Poor in Rural India.” Journal of Microfinance 7, no. 2 (Winter): 71-99.

Mahabub-ul, Islam. 1996. "Peer Monitoring in the Credit Market" Journal of Contemporary Asia 26, no. 4: 452-465.

Mahoney, James. 2010. "After KKV: The New Methodologies of Qualitative Research" World Politics 62, no. 1 (January): 120-147. 
Malamut, Guiherme. 2006. Microfinance In Bolivia, Bangladesh and Brazil: Three Complementary Models. Microfinance Development Projects.

Malana, Daniel, and Louisa Malobola. 2004. "Impact Assessment of Microfinance Programs: Including Lessons from Khula Enterprise Finance" Development South Africa 21, no. 5 (December): 799-814.

Marconi, Reynaldo, and Paul Mosley. 2006. "Bolivia During the Global Crisis 1998-2004: Towards a 'Macroeconomics of Microfinance"' Journal of International Development 18: 237-261.

Maresca, John. 2003. "The Role of the Private Sector in Post-Conflict Reconstruction" Refugee Survey Quarterly 22, no. 4: 161-164.

Marr, Ana. 2004. "A Challenge to the Orthodoxy Concerning Microfinance and Poverty Reduction." Journal of Microfinance 5, no. 2: 7-42. . 2002. "Studying Group Dynamics: An Alternative Analytical Framework for the Study of Microfinance Impacts on Poverty Reduction" Journal of International Development 14, no. 4: $511-534$.

Marr, Ana, and Paola Tubaro. 2011. "Field Report: Crisis in Indian Microfinance and a Way Forward: Governance Reforms and the Tamil Nadu Model" Journal of International Development 23: 996-1003.

Matin, Imaran, David Hulme, and Stuart Rutherford. 2002. "Finance for the Poor: From Microcredit to Microfinancial Services" Journal of International Development 14, no. 2: 273-294.

Mayer, Margit, and Katherine Rankin. 2002. "Social Capital and (Community) Development: A North/South Perspective" Antipode 34, no. 4: 804-808.

Mayo, Yolanda Quinones, and Rosa Perla Resnick. 1996. "The Impact of Machismo on Hispanic Women" Affilia 11, no 3 (Fall): 257-277.

Mayoux, Linda. 1999. “Questioning Virtuous Spirals: Microfinance and Women's Empowerment in Africa" Journal of International Development 11: 957-984.

McAuley, Christopher. 2006. "Oliver Cox and the Roots of World Systems Theory" American Capitalism: Social Thought and Political Economy in the Twentieth Century. University of Pennsylvania Press. 
McGuire, Paul, and John Conroy. 2000. "The Microfinance Phenomenon" Asia-Pacific Review 7, no. 1 (May): 90-108.

. 1998. "Effects on Microfinance of the 1997-1998 Asian Financial Crisis" Second Annual Seminar on New Development Finance. Goethe University, Frankfurt (September21-25): 122.

McIntosh, Craig, and Bruce Wydick. 2005. "Competition and Microfinance" Journal of Development Economics 78: 271-298.

McIntosh, Craig, Alan de Janvry, and Elisabeth Sadoulet. 2005. "How Rising Competition among Microfinance Institutions Affects Incumbent Lenders” The Economic Journal 115, no. 506 (October): 987-1004.

Meagher, Patrick. 2002. "Microfinance Regulation in South Africa: A Comparative Perspective" Development Bulletin 57 (February): 48-52.

Meagher, Patrick, Pilar Campos, Robert Peck Christen, Kate Druschel, Joselito Gallardo, and Sumantoro Martowijoyo. 2006. Microfinance Regulation in Seven Countries: A Comparative Study. IRIS Center at the University of Maryland: 1-189.

Meehan. J. 2005. "Tapping Financial Markets for Microfinance” Grameen Foundation UA Publication Series 2005.

Mel, Suresh de, David McKenzie, and Christopher Woodruff. 2009. "Are Women more Credit Constrained? Experimental Evidence on Gender and Microenterprise Returns" American Economic Journal: Applied Economics 1, no.3 (July): 1-32.

Menon-Sen, Kalyani. 2012. "Fraying at the Edges? Discordant Notes from the Margins of India Shining." In Penny Johnson and Sawsan Wadi, eds., Review Of Women's Studies 7. Institute of Women's Studies, Birzeit University: 70-84.

Merry, Sally Engle. 2002. "Moving Beyond Ideology Critique to the Analysis of Practice" Law and Social Inquiry 27, no. 3: 609-612.

Mersland, Roy. 2007. "The Agenda and Relevance of Recent Research in Microfinance" MPRA Paper 2433 (March): 1-30.

Mersland, Roy, and Ludovic Urgeghe. 2013. "International Debt Financing and Performance of Microfinance Institutions.” Strategic Change 22: 17-29. 
Meyer, JW, Boli, J, Thomas, GM, Ramirez, FO (1997) World society and the nation-state. American Journal of Sociology 103(1): 144-181.

Microfinance Information Exchange. 2010. http://www.themix.org/socialperformance/Indicators.

Milana, Carlo and Arvind Ashta. 2012. "Developing Microfinance: A Survey of the Literature." Strategic Change 21: 299-330.

Miller, Harry, and Fred Kirschstein. 1988. "Strategic Considerations for Promoting MicroEnterprises in Developing Countries: A Role for Higher Education Institutions" International Review of Education 34, no. 4: 495-499.

Mills, Sophie. 2007. "The Kuyasa Fund: Housing Microcredit in South Africa" SAGE 19, no. 2: 457-469.

Mishra, Sangita. 2004. "Beyond Micro Credit: Putting Development Back into Micro-Finance by Thomas Fisher; M.S. Sriram” Indian Economic Review 39, no. 2 (July-December): 401-406.

Miyashita, Yoko. 2000. "Microfinance and Poverty Alleviation: Lessons from Indonesia's Village Banking System" Pacific Rim Law and Policy Journal 10, no. 1 (December): 147189

Moll, Henk A.J.. 2005. "Microfinance and Rural Development: A Long-Term Perspective." Journal of Microfinance 7, no. 1 (Winter): 13-31.

Monasterios P, Karin. 2007. "Bolivian women's organizations in the MAS era." NACLA Report on the Americas 40, no. 2: 33-37.

Monon-Sen, Kalyani. 2012. "Fraying at the Edges? Discordant Notes from the Margins of India Shining" in Johnson and Wadi, eds, Review of Women's Studies 7 (Institute of Women's Studies Birzeit University): 70-84.

Montgomery, R. 1996. "Disciplining or Protecting the Poor: Avoiding the Social Costs of Peer Pressure in Microcredit Schemes" Journal of International Development 8, no. 2: 289-305.

Moodie, Megan. 2013. "Microfinance and the Gender of Risk: The Case of Kiva.org" Signs 38, no. 2 (Winter): 279-302.

Moon, Bruce. 1985. "Consensus or Compliance? Foreign Policy Change and External Dependence" International Organization 39, no 2 (Spring): 297-329. 
Moore, Mike. 2003. A World Without Walls: Freedom, Development, Free Trade and Global Governance. Cambridge: University Press.

Morais, Neavis, and Mokbul Morshed Ahmad. 2011. "NGO-Led Microfinance: Potentials and Challenges in Conflict Areas" Journal of International Development 23: 629-640.

Morduch, Jonathan. 2000. “The Microfinance Schism” World Development 28, no. 4: 617-629. . 1999. "The Microfinance Promise" Journal of Economic Literature 37 (December): 15691614.

. 1999. "The Role of Subsidies in Microfinance: Evidence from the Grameen Bank" Journal of Development Economics 60: 229-248.

Morris, Gayle, and Carolyn Barnes. 2005. "An Assessment of the Impact of Microfinance: A Case Study from Uganda” Journal of Microfinance 7, no. 1 (Summer): 39-54.

Mosley, Paul. 1996. "Methamorphosis from NGO to Commerical Bank: The Case of BancoSol in Bolivia” in David Hulme and Paul Mosely Finance against Poverty volume 2: 1-31.

Mosley, Paul, and June Rock. 2004. "Microfinance, Labour Markets, and Poverty in Africa: A Study of Six Institutions” Journal of International Development 16: 467-500.

Muhammad, Anu. 2009. "Grameen and Microcredit: A Tale of Corporate Success" Economic and Political Weekly 44, no. 35 (August-September): 35-42.

Munoz, Heraldo, ed. 1981. From Dependence to Development: Strategies to Overcome Underdevelopment and Inequality. Colorado, Westview Press.

Nair, Tara. 2001. "Institutionalising Microfinance in India: An Overview of Strategic Issues" Economic and Political Weekly 36, no. 4 (January-February): 399-404.

Nasir, Sibghatullah. 2013. "Microfinance in India: Contemporary Issues and Challenges." Middle-East Journal of Scientific Research 15, no. 2: 191-199.

Natsios, Andrew S. 2005. "The Nine Principles of Reconstruction and Development" Parameters 35, no. 3 (Autumn): 4-20.

Ncube, Mthuli, Abebe Shimeles, and Audrey Verdier-Chouchane. 2012. "South Africa's Quest for Inclusive Development” African Development Bank Group Working Paper no 160 (May): 1-28. 
Newby, Les. 1999. "Sustainable Local Economic Development: A New Agenda for Action?" Local Environment 4, no. 1: 67-72.

Nghiem, Son, Tim Coelli, and Prasada Rao. 2012. "Assessing the Welfare Effects of Microfinance in Vietnam: Empirical Results from a Quasi-Experimental Survey" The Journal of Development Studies 48, no. 5: 619-632.

Nieto, Begona G. 2005. "Private Funding of Microcredit Schemes: Muchado About Nothing?" Development in Practice 15, no. 3 \& 4 (June): 490-501.

Nicholas, Sabin. 2016. "Microfinance: A field in flux." In Alex Nicholls, Rob Paton, and Jed Emerson, eds. Social Finance. Oxford University Press: 1-31

Nourse, Timothy. 2001. "The Missing Parts of Microfinance: Services for Consumption and Insurance" School of Advanced International Studies Review 21, no. 1 (Winter/Spring): 6169.

Nunnenkamp, Peter. 1999. "Latin America after the currency crash in Brazil: why the optimists may be wrong.” Institute for World Economy Publishing no. 337 (April): 1-19.

O’Brien, Barclay. 2008. "The Role of Non-Government Organizations in Microfinance” Savings and Development 32, no. 1: 103-115. . 2006. "Valuing Microfinance Institutions" Savings and Development 30, no. 3: 275-296.

O’Brien, Robert, and Marc Williams. 2007. Global Political Economy: Evolutions and Dynamics $2^{\text {nd }}$ ed. Palgrave McMillian Publishing.

Ohanyan, Anna. 2002. "Post-Conflict Global Governance: The Case of Microfinance Enterprise Networks in Bosnia and Herzegovina" International Studies Perspectives 3: 396-416. . 2007. "The Politics of Microcredit" Case Study for the UN Vision Project on Global Public Policy Networks (November): 1-45.

OikoCredit. 2013. Accessed June 27, 2020 from https://www.oikocredit.coop/en/

Oliva-Beltran, Gonzalo. 2008. "Microfinance: From Social to Business" Latin American Regional Forum (September): 38-48.

Olivares-Polanco, Francisco. 2005. "Commercializing Microfinance and Deepening Outreach? Empirical Evidence from Latin America.” Journal of Microfinance 7, no. 2 (Winter): 47-69. 
Oliver, Christine. 1997. "Sustainable Competitive Advantage: Combining Institutional and Resource Based Views.” Strategic Management Journal 18, no. 9 (October): 697-713.

Olsen, Tricia. 2010. "New Actors in Microfinance Lending: The Role of Regulation and Competition in Latin America" Perspectives on Global Development and Technology 9: 500-519.

Olu, Ojo. 2009. "Impact of Microfinance on Entrepreneurial Development: The Case of Nigeria" The International Conference on Administration and Business. Bucharest (November): 536545.

Olufemi, Olusola. 2004. "Women and the Burden of Unsustainable Development: Practice and Policy Contradictions" Development in Practice 14, no. 3 (April): 428-451.

Onis, Ziya. 1995. "The Limits of Neoliberalism: Toward a Reformulation of Development Theory” Journal of Economic Issues 29, no. 1 (March): 97-119.

Otero, Maria. 2000. "Bringing Development Back, into Microfinance" Journal of Microfinance 1, no. 1: 8-19. . 2009. "Governance of Microfinance Institutions" Office of Development Studies UN Development Program: 1-17.

Oyeshile, Olatunji A. 2004. "Communal Values, Cultural Identity, and the Challenge of Development in Contemporary Africa" The Journal of Social, Political, and Economic Studies 29, no. 3 (Fall): 291-303.

Peet, Richard., 2003. Unholy Trinity: The IMF, World Bank, and WTO. London: Zed Books.

Pena De La, Guillermo. 2006. “A new Mexican Nationalism? Indigenous Rights, Constitutional Reform and the Conflicting Meanings of Multiculturalism" Nations and Nationalism 12, no 2: 279-302.

Penkar, Daniel, and Rajendra Takale. 2013. "Microfinance Institutions in India: Do they Need to be Regulated?" Internatinal Referred Journal of Arts, Science, and Commerce 1, no. 1 (January): 32-39.

Perez Jr., Louis. 1990. “Dependency” The Journal of American History 77, no.1 (June): 133-142.

Philips, Jason. 2007. "Challenges to the Effective Implementation of Microfinance Programmes in Refugee Settings" Livelihoods FMR 20: 5-8 
Porta, Donatella Della, and Michael Keeting, eds. 2008. Approaches and Methodologies in the Social Sciences. Cambridge Press.

Pretes, Michael. 2002. "Microequity and Microfinance" World Development 30, no. 8: 13411353.

Prince, Jonathan. 2007. "Promoting Consumer Empowerment through Entrepreneurship: A Proposal" Psychiatric Rehabilitation Journal 30, no. 3: 223-228.

Pro Mujer. Accessed July 2020: http://promujer.org/who-we-are/our-history/ . Accessed July 10, 2020: https://promujer.org/2017/11/21/pro-mujer-microsoft-digitalskills-training/ . Accessed July 10, 2020: https://promujer.org/2016/10/13/maria-guerrero-vargas/ Accessed July 10, 2020: https://promujer.org/2016/10/13/elsa-castillo-garcia/

Przeworski, Adam, and Henry Teune. 1970. The Logic of Comparative Social Inquiry. Krieger Publishing Company.

Puchala, Donald, and Raymond Hopkins. 1982. "International Regimes: Lessons from Inductive Analysis” International Organization 36, no 2 (Spring): 245-275.

Putnam, Robert. 1988. "Diplomacy and Domestic Politics: The Logic of Two-Level Games" International Organization 42, no 3 (Summer): 427-460.

Raco, Mike. 2005. "Sustainable Development, Rolled-out Neoliberalism and Sustainable Communities" Antipode 37, no.2 (March): 324-347.

Rahman, Aminur. 2001. Women and microcredit in rural Bangladesh: An anthropological study of Grameen Bank lending. Westview Press.

Rahman, M. Wakilur, Jianchao Luo, Salehudin Ahmed, and Wang Xiaolin. 2012. "The Synthesis of Grameen Bank, BRAC and ASA Microfinance Approaches in Bangladesh" World Applied Sciences Journal 20, no. 7: 1055-1062.

Ramani, Geetha Rao. 2007. "From NGO to MFI: A Guidebook for Successful Transformation." ESR Review 9, no. 2 (Fall): 34-35. 
Rankin, Katherine. 2002. "Social Capital, Microfinance, and the Politics of Development" Feminist Economics 8, no. 1: 1-24. . 2001. "Governing Development: Neoliberalism, Microcredit, and Rational Economic Woman" Economy and Society 30, no. 1 (February): 18-37.

Rath, Nilakantha. 2008. "Microfinance Regulation Bill: A rejoinder" Economic and Political Weekly 43, no 19 (May): 84-85.

Rauf, Shahnaz, and Tahir Mahmood. 2009. "Growth and Performance of Microfinance in Pakistan” Pakistan Economic and Social Review 47, no. 1 (Summer): 99-122.

Rhyne, Elisabeth. 2003. "Making Microfinance Transparent: ACCION Policy Paper on Transparency" ACCION InSight no. 3 (October): 1-7.

_. 2001. "Commercialization and Crisis in Bolivian Microfinance" Microenterprise Best Practices PCE-C-00-96-90004-00 (November): 1-25.

Rhyne, Elisabeth, and Andres Guimon. 2007. "The Banco Compartamos Initial Public Offering" ACCION InSight 23: 1-20.

Robinson, Marquerite S. 2002. The Microfinance Revolution: Sustainable Finance for the Poor. Washinton, D.C.: Published by the International Bank for Reconstruction and Development/The World Bank.

_ 2001. The Microfinance Revolution. New York: Open Society Press.

Rodrik, Dani. 1996. "Understanding Economic Policy Reform” Journal of Economic Literature 34, no. 1 (March): 9-41.

Rogerson, Christian. 2004. "Pro-poor Local Economic Development in Post-Apartheid South Africa" IDPR 26, no. 4: 401-423.

Rogerson, C.M. 2001. "In Search of the African Miracle: Debates on Successful Small Enterprise Development in Africa" Habitat International 25: 115-142.

Rose, Richard. 1991. “What is Lesson-Drawing?” Journal of Public Policy 11, no 1 (Jan-Mar): 3-30.

Rosenberg, Richard. 2007. "CGAP Reflections on the Compartamos Initial Offering" Focus Note 42: 1-24. 
Rosengard, Jay. 2004. "Banking on Social Entrepreneurship: The Commercialization of Microfinance" Mondes en Developpement 32, no. 126: 25-36.

Ruggie, John Gerard. 1975. “International Responses to Technology" International Organization 29, (Summer): 557-584.

Rydin, Yvonne, and Nancy Holman. 2004. "Re-evaluating the Contribution of Social Capital in Achieving Sustainable Development" Local Environment 9, no. 2 (April): 117-133.

Sabatier, Paul, ed. 2007. Theories of the Policy Process. Colorodo: Westview Press.

Sachs, Jeffery. 2005. The End of Poverty: Economic Possibilities for Our Time. New York: Penguin Books. . 2005. "The Development Challenge" Foreign Affairs 84, no. 2 (March/April): 78-90.

Sader, Emir. 2009. “Postneoliberalism in Latin America.” Development Dialogue 51 (January): 171-180.

Sandbrook, Richard. 2000. "Globalization and the Limits of Neoliberal Development Doctrine: Development as Freedom by Amartya Sen" Third World Quarterly 21, no. 6 (December): 1071-1080.

Sane, Renuka, and Susan Thomas. 2012. "What Should Regulation do in the Field of MicroFinance?” Financial Sector Regulatory Reform Project Working Paper 2012-012 (March): $1-26$.

Sanyal, Paromita. 2009. "From Credit to Collective Action: The Role of Microfinance in Promoting Women's Social Capital and Normative Influence" American Sociological Review 74, no. 4 (August): 529-550.

Sapienza, Paola. 2004. "The Effects of Government Ownership on Bank Lending" Journal of Financial Economics 72, no. 2: 357-384.

Satish, P. 2005. "Mainstreaming of Indian Microfinance" Economic and Political Weekly 40, no. 17 (April): 1731-1739.

Schoombee, Andrie. 2000. "Banking for the Poor: The Successes and Failures of South African Banks" Paper presented at the DEVNET conference on Poverty, Prosperity, and Progress, Victoria University of Wellington, Wellington, New Zealand, 17-19 November. 
Schreiner, Mark. 2004. "Scoring Arrears at a Microlender in Bolivia" Journal of Microfinance 6, no. 2 (Winter): 65-88. . 2002. "Aspects of Outreach: A Framework for Discussion of the Social Benefits of Microfinance" Journal of International Development 14: 591-603. . 2001. "Informal Finance and the Design of Microfinance" Development in Practice 11, no. 5 (November): 637-643.

Schreiner, Mark, Gary Woller. 2003. "Microenterprise Development Programs in the US and in the Developing World" World Development 39, no. 9: 1567-1580.

Schreiner, Mark, and Janine Leon. 2002. "Microfinance for Microenterprise: The State of the Art" Savings and Development 26, no. 4: 329-354.

Schulpen, Lau. 2002. "Private Sector Development: Policies, Practices, and Problems" World Development 30, no. 1: 1-15.

Sebenius, James. 1992. "Challenging Conventional Explanations of International Cooperation: Negotiation Analysis and the Case of Epistemic Communities" International Organization 46, no. 1 (Winter): 323-365.

Sen, Amartya. 2005. "How Does Development Happen?" The Cato Journal 25, no. 3: 455-439.

Serrano-Cinca, C. and B. Gutierrez-Nieto. 2012. "Microfinance, the long tail and mission drift." Research Institute in Management Sciences Centre Emile Bernheim CEB Working Paper no 12/001: 1-22.

Shankar, Savita, and Mukul Asher. 2010. "Regulating Microfinance: A Suggested Framework" Economic and Political Weekly 45, no. 1 (Jan): 15-18.

Sherbiny, Naiem. 2005. “Can Russia and Germany Save the Middle East?” Russia in Global Affairs 12, no. 1 (March): 59-65.

Shylendra, H.S. 2006. "Mainstreaming Microfinance for Poverty Alleviation: Need for a Proactive Policy and Regulatory Framework" in YSP Thorat, ed. Towards a Sustainable Microfinance Outreach in India: Experiences and Perspectives. Microcredit Innovations Department Thoughtscape Design Studio (May): 173-204. 
Sievers, Merten, and Paul Vandenberg. 2007. "Synergies Through Linkages: Who Benefits From Linking Microfinance and Business Development Services" World Development 35, no. 8: 1341-1358.

Silverberg, Sarah. 2014. "One Size Does Not Fit All: A Study of Microfinance Practices in Peru” Undercurrent Journal 10, no 2 (Fall/Winter): 45-53

Simanowitz, Anton. 1999. "Effective Strategies for Reaching the Poor" Development Southern Africa 16, no. 1 (Autumn): 169-182.

Sinclair, Hugh. 2012. Confessions of a Microfinance Heretic: How Microlending Lost Its Way and Betrayed the Poor. Barrett-Koehler Publishers.

Singh, Naresh. 2004. "The Miracles of Barefoot Capitalism: A Compelling Case for Microcredit” Journal of Microfinance 6, no. 1 (Summer): 127-130.

Sinha, France. 2005. "Access, Use and Contribution of Microfinance in India: Findings from a national Study" Economic and Political Weekly 40. No 17 (April): 1714-1719.

Smirnov, G., S. Bessonov, eds. 1979. Planning in Developing Countries Theory and Methodology. Unitar Publishing

Snow, Douglas, and Terry Buss. 2001. "Development and the Role of Microcredit" Policy Studies Journal 29, no. 2: 296-308.

Snyder, Jack. 1991. Myths of Empire: Domestic Politics and International Ambition. Ithaca, Cornell University Press.

Soederberg, Susanne. 2013. "The Politics of Debt and Development in the New Millennium: An Introduction" Third World Quarterly 34, no 4: 535-546.

Solingen, Etel. 2009. "The Global Context of Comparative Politics" in Lichback and Zucerman Comparative Politics Rationality, Culture, and Structure (Cambridge Press): 220-259.

Solle de Hillari, Caroline. 2013. "Microinsurance: Healthy Clients" Development and Cooperation Magazine no 11: 415.

Sriram, M.S. 2010. "Microfinance Industry in India: More Thoughts." Economic and Political Weekly 47, no. 50 (December): 110-112. 
.2010. "Microfinance: A Fairy Tale Turns into a Nightmare." Economic and Political Weekly 45, no. 43 (October): 10-13. . 2005. "Microfinance and the State: Exploring Areas and Structures of Collaboration" Economic and Political Weekly 40, no. 17 (April): 1699-1704.

Sriram, M.S., and Rajesh S. Upadhyayula. 2004. "The Transformation of the Microfinance Sector in India: Experiences, Options, and Future" Journal of Microfinance 6, no. 2 (Winter): 89-112.

Staveren, Irene V. 2003. "Beyond Social Capital in Poverty Research" Journal of Economic Issues 38, no. 2 (June): 415-423. . 2001. "Gender Biases in Finance" Gender and Development 9, no. 1 (March): 9-17.

Sterling-Folker, Jennifer. 2000. "Competing Paradigms or Birds of a Feather? Constructivism and Neoliberal Intuitionalism Compared" International Studies Quarterly 44, no. 1 (March): 97-119.

Stevens, Kris, and John Morris. 2001. "Struggling Toward Sustainability: Considering Grassroots Development” Sustainable Development 9: 149-164.

Stone, Diane. 1999. "Learning Lessons and Transferring Policy across Time, Space, and Disciplines" Politics 19, no. 1: 51-59.

_. 2004. "Transfer Agents and Global Networks in the Transnationalization of Policy" Journal of European Public Policy 11, no. 3 (June): 545-566.

Swain, Ranjula Bali, and Emilia Liljefrost, eds. 2005. The Democratization of Finance - Future Directions for Microfinance. Uppsala: Collegium for Development Studies.

Taylor, Marcus. 2011. "Freedom from Poverty is not for Free: Rural Development and the Microfinance Crisis in Andhra Pradesh, India" Journal of Agrarian Change 11, no 4 (October): 484-504. . 2012. "The Antinomies of Financial Inclusion: Debt, Distress and the Workings of Indian Microfinance" Journal of Agrarian Change 12, no. 4 (October): 601-610

Tassel, Eric Van. 2004. "Household Bargaining and Microfinance" Journal of Development Economics 74: 449-468. 
Tavanti, Marco. 2013. "Before microfinance: The social value of microsavings in Vincentian poverty reduction." Journal of Business Ethics 112, no. 4: 697-706.

Tedeschi, Gwendolyn A. 2006. "Here Today, Gone Tomorrow: Can Dynamic Incentives Make Microfinance More Flexible?" Journal of Development Economics 80: 84-105.

Thorat, YSP, ed. 2006. Towards a Sustainable Microfinance Outreach in India: Experiences and Perspectives. Microcredit Innovations Department, Mumbai.

Thorp, Rosemary, Frances Stewart, and Ayrik Heyer. 2005. "When and How Far is group Formation a Route Out of Chronic Poverty?" World Development 33, no. 6: 907-920.

Thrikawala, Sujani, Stuart Locke, and Krishna Reddy. 2013. "Social Performance of Microfinance Institutions: Does Existing Practice Imply a Social Objective?” American Journal of Business and Management 2, no. 2: 173-180.

Tongquan, Sun. 2008. "The Policy and Legal Framework for Microfinance in China" World Microfinance Forum Geneva (February): 1-17.

Torre, Jordi de la, Xavier Gine, and Tara Vishwanath. 2011. "After the Microfinance Crises: Assessing the Role of Government-Led Microcredit Alternatives" World Bank Policy Research Working Paper 5808 (September): 1-14.

Townsend, Janet, Gina Porter, and Emma Mawdsley. 2004. "Creating Spaces of Resistance: Development NGOs and their Clients in Ghana, India, and Mexico" Antipode 36, no. 5: 871889.

Townsend, Robert. 2003. "Microcredit and Mechanism Design" Journal of European Economic Associations 1, no. 2 \& 3 (April/May): 468-477.

Tressel, Thierry. 2003. "Dual Financial Systems \& Inequalities in Economic Development" Journal of Economic Growth 8: 223-257.

Tucker, Michael, and Gerard Miles. 2004. "Financial Performance of Microfinance Institutions: A Comparison to Performance of Regional Commercial Banks by Geographic Regions." Journal of Microfinance 6, no. 1 (Summer): 41-54.

Tucker, Michael, and Winston Tellis. 2005. "Microfinance Institutions in Transition: Fonkoze in Haiti Moves toward Regulated banking Status.” Journal of Microfinance 7, no. 2 (Winter): 101-125. 
Uddin, Mohammad Jasim. 2013. Microcredit, Gender and Neoliberal Development in Bangladesh. Helsinki University Press.

Vanroose, Annabel. 2008. "What Macro Factors Make Microfinance Institutions Reach Out?" Savings and Development 32, no.3: 153-174.

Vargus, Claudia M. 2000. "Community Development and Micro-Enterprises: Fostering Sustainable Development" Sustainable Development 8, no. 1: 11-26.

Vatta, Kamal. 2003. "Microfinance and Poverty Alleviation" Economic and Political Weekly 38, no. 5 (February): 432-433.

Vijaya, B. and Veerendrakumar. 2013. "Microfinance to Rural Poor: A Tool for Poverty Alleviation." International Refereed Journal of Arts, Science and Commerce 1, no. 1 (January): 7-11.

Vonderlack, Rebecca, and Mark Schreiner. 2002. "Women, Microfinance, and Savings: Lessons and Proposals" Development in Practice 12, no. 5 (November): 602-612.

Wagner, Charlotte. 2012. "From Boom to Bust: How Different Has Microfinance been from Traditional Banking" Development Policy Review 30, no. 2: 187-210.

Walt, Vivienne. 2012. "Does Microfinance Really Work? A New Book Says No" Time (January 6): http://content.time.com/time/world/article/0,8599,2103831,00.html.

Weber, Heloise. 2002. "The Imposition of a Global Development Architecture: The Example of Microcredit" Review of International Studies 28: 537-555. . 2004. "Reconstituting the 'Third World'? Poverty Reduction and Territoriality in the Global Politics of Development” Third World Quarterly 25, no. 1: 187-206. . 2004. “The 'New Economy' and Social Risk: Banking on the Poor?" Review of International Political Economy 11, no. 2 (May): 356-386.

Wells, H. 1968. The Modernization of Puerto Rico: A political study of changing values and institutions. Harvard University Press.

Wenner, M. 1995. "Group Credit: A Means to Improved Information Transfer and Loan Repayment Performance" Journal of Development Studies 32, no. 2: 263-281. 
Wilson, Tamar Diana. 2014. "Violence Against Women in Latin America" Latin American Perspectives 41, no 1 (Jan.): 3-18.

Woller, Gary. 2007. "Trade-offs Between Social and Financial Performance" ESR Review 9, no. 2 (Fall): 14-19. 2002. "From Market Failure to Marketing Failure: Market Orientation as the Key to Deep Outreach in Microfinance" Journal of International Development 14: 305-324.

Woller, Gary, Christopher Dunford, and Warner Woodworth. 1999. "Where to Microfinance" International Journal of Economic Development, 1:29-64

Woller, Gary, and Robert Parsons. 2002. "Assessing the Community Economic Impact of Microfinance Institutions" Journal of Development Entrepreneurship 7, no. 2 (August): 133-150.

Woller, Gary, and Warner Woodworth. 2001."Microcredit and Third World Development Policy" Policy Studies Journal 29, no. 2: 265-267.

_ 2001. "Microcredit as a Grass-Roots Policy for International Development" Policy Studies Journal 29, no. 2: 267-283.

Wood, Geoffrey, and Iffath Sharif. 1997. Who Needs Credit? Poverty and Finance in Bangladesh. Dhaka, Universit Press Limited.

Woodworth, Warner. 2008. "Reciprocal Dynamics: Social Capital and Microcredit" ESR Review 10, no 2 (Fall): 36-42.

Woolcock, Michael. 1999. "Learning from Failure in Microfinance: What Unsuccessful Cases Tell Us About How Group-Based Programs Work" The American Journal of Economics and Sociology 58, no. 1: 17-42.

Woolcock, Michael, and Deepa Narayari. 2000. "Social Capital: Implications for Development Theory, Research, and Policy" The World Bank Research Observer 15, no. 2 (August): 225249.

World Bank. 2009. News Release no. 2009/240/PREM, World Bank, 11 March 2009

World Summit. 2005. http://www.un.org/Docs/journal/asp/ws.asp?m=A/RES/60/1). 
Wright, Graham. 2000. Microfinance Systems: Designing Quality Financial Services for the Poor. New York: Zed Books Publishing. . 2000. "Regressive Reproduction or Progressive Evolution?" Journal of Microfinance 2, no. 2 (Fall): 61-82.

Wright, Kate, and James Copestake. 2004. "Impact Assessment of Microfinance using Qualitative Data: Communication between Social Scientists and Practitioners Using the Quip" Journal of International Development 16: 355-367.

Wydick, B. 1999. "Can Social Cohesion be Harnessed to Repair Market Failures? Evidence from Group-Based Lending in Guatemala" Economic Journal 109, no. 457: 463-475.

Yaron, Jacob. 1994. "What Makes Rural Finance Institutions Successful?" The World Bank Research Observer 9, no. 1 (January): 49-70.

Yaron, Jacob, and Ronny Manos. 2007. "Determining the Self-Sufficiency of Microfinance Institutions" Savings and Development 31, no. 2: 131-160.

Yergin, Daniel, and Joseph Stanislaw. 2002. Commanding Heights: The Battle for the World Economy. Touchstone Publishing.

Young, Stephen.. 2010. “The 'Moral Hazards' Of Microfinance: Restructuring Rural Credit in India" Antripode 42, no. 1: 201-223.

Yunus, Muhammad. 1999. Banking to the Poor: Micro-Lending and the Battle Against World Poverty. New York: PublicAffairs Publishing. . 2008. "Creating a World Without Poverty: Social Business and the Future of Capitalism" Global Urban Development Magazine 4, no. 2 (November): 16-41.

Zeller, Manfred, and Julia Johannsen. 2008. "Is there a Difference in Poverty Outreach by type of Microfinance Institution? Country Studies from Asia and Latin America" Savings and Development 32, no. 3" 227-269.

Zohir, Sajjad, and Imran Matin. 2004. "Wider Impacts of Microfinance Institutions: Issues and Concepts" Journal of International Development 16: 301-330. 